
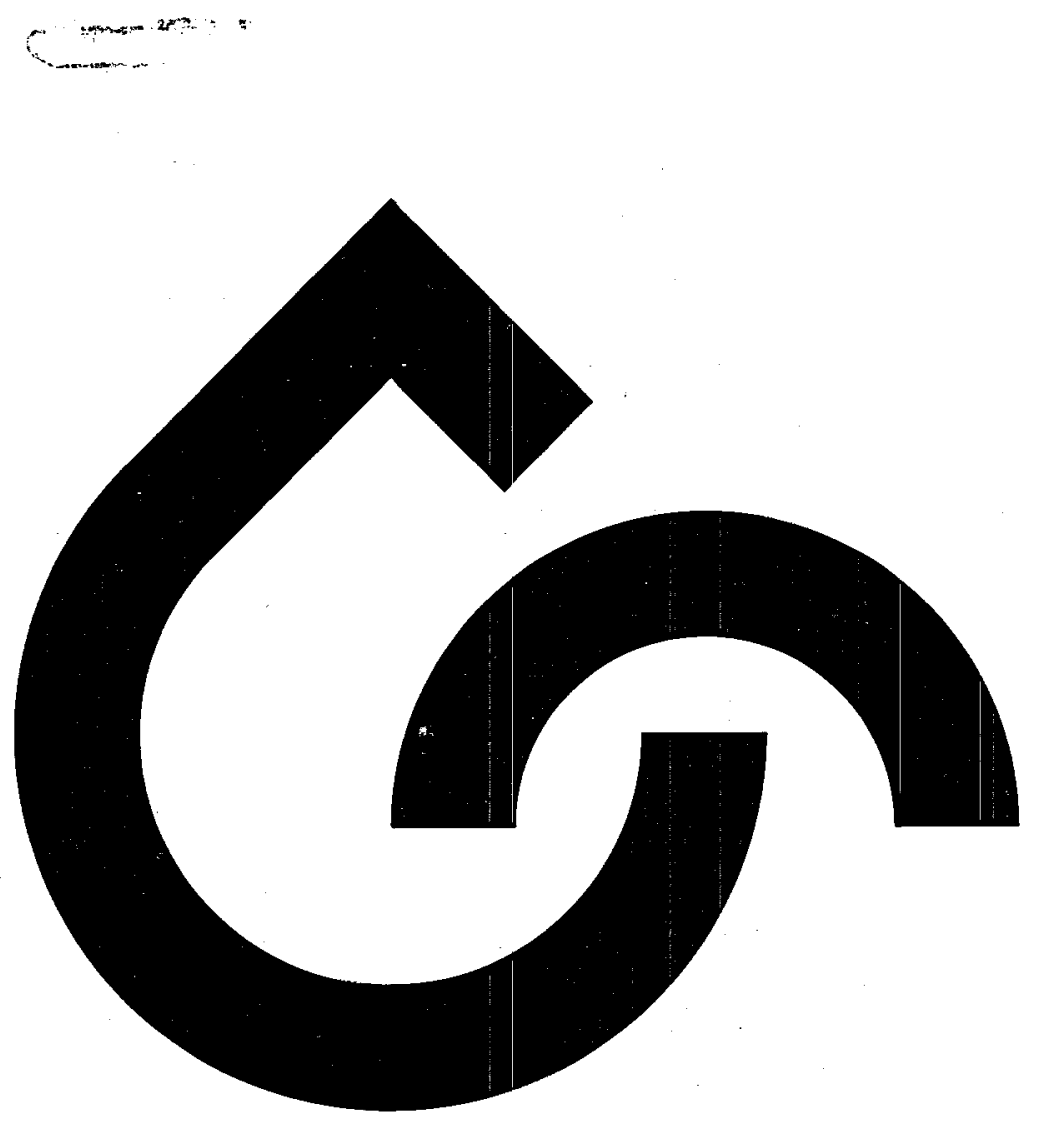

\section{Direct use} geothermal energy utilization for ethanol production and commercial mushroom growing at Brady's Hot Springs, Nevada.

\section{Volume 1 Technical feasibility.}

Feasibility study performed under DOE Grant DE-FG03-80SF 11428.

Geothermal Food Processors, Inc. September, 1981 


\section{DISCLAIMER}

This report was prepared as an account of work sponsored by an agency of the United States Government. Neither the United States Government nor any agency Thereof, nor any of their employees, makes any warranty, express or implied, or assumes any legal liability or responsibility for the accuracy, completeness, or usefulness of any information, apparatus, product, or process disclosed, or represents that its use would not infringe privately owned rights. Reference herein to any specific commercial product, process, or service by trade name, trademark, manufacturer, or otherwise does not necessarily constitute or imply its endorsement, recommendation, or favoring by the United States Government or any agency thereof. The views and opinions of authors expressed herein do not necessarily state or reflect those of the United States Government or any agency thereof. 


\section{DISCLAIMER}

Portions of this document may be illegible in electronic image products. Images are produced from the best available original document. 


\section{$\because \quad i^{\prime} \quad$ NOTICE \\ NOTICE
REPORT ARE LUEGIELE DDOE \\ $\frac{\text { POBTHOHS/OF THIS REPORT ARE ILEGIELE. }}{\text { it has been reproduced from the tost }}$}

avallable copy to permit the broatiest

possible availability.

CONTROL COPY

\section{DISCLAIMER}

This report was prepared as an account of work sponsored by an agency of the United States Government. Neither the United States Government nor any agency thereof, nor any of their employees, makes any warranty, express or implied, or assumes any legal liability or responsibility for the accuracy, completeness, or usefulness of any information, apparatus, product, or process disclosed, or represents that its use would not infringe privately owned rights. Reference herein to any specific commercial product, process, or service by trade name, trademark, manufacturer, or otherwise does not necessarily constitute or imply its endorsement, recommendation, or favoring by the United States Government or any agency thereof. The views and opinions of authors expressed herein do not necessarily atate or reflect those of the United States Government or any agency thereof.

VOLUME I

\section{DE85 004487}

FEASIBILITY STUDY

ETHANOL PRODUCTION

AND

MUSHROOM GROWING

CASCADED USES OF

GEOTHERMAL ENERGY

DOE GRANT DE-FG03-8OSF 11428 
VOLUME I

TABLE OF CONTENTS

SECTION

1

SUMMARY

2

BACKGROUND

2.1 Geothermal Resource

2.2 Geothermal. Food Processors

2.3 Prior Government Support

2.4 Raw Materials Availability

2.5 Technical Process and Risks - Ethanol

2.6 Economics

2.7 Three Phase Program

ETHANOL PRODUCTION FEASIBILITY

4

MUSHROOM PRODUCTION FEASIBILITY

4.1 Overview

$\therefore$.

4.2 Automated Growing and Harvesting

4.3 Direct-Use Application of Geothermal Energy

4.4 Additional Uses

4.5 Design Assessment

4.6 Growing and Harvesting Equipment

4.7 Heat Exchangers

4.8 Construction Management and Quality Control

4.9 Operations

5

RESERVOIR ASSESSMENT

5.1 Overview

5.2 Design of the Well Test

5.3 Instrumentation and Test Procedure

5.4 Analysis of Well Test Data

5.5 Conclusions and Recommendations

6

COMMERCIAL VIABILITY

6.1 Existing Site Sultability

6.2 Resource Base

6.3 Technical Readiness

6.4 Raw Materials and By-Products

6.5 Energy Balances 
TABLE OF CONTENTS (continued)

SECTION

7

REQUIRED WORK TASKS

7.1 General Scope Phase I Tasks

7.2 General Scope Phase II Tasks

7.3 General Scope Phase III Tasks

7.4 Team Responsibilities by Task

8

POTENTIAL CONTRACTORS

8.1 Overall Program Management - Andersen Group, Inc.

8.2 Morrison-Knudsen Company, Inc.

8.3 S E A, Inc.

$8.4 \mathrm{Ag}$ West, Inc.

8.5 Raphael Katzen Associates International, Inc.

8.6 GeothermEx, Inc.

Appendix
A. CALCULATIONS USING THEIS SOLUTION
B. CALCULATIONS USING LINEAR FLOW SOLUTION
C. TABLES AND FIGURES 
VOLUME II

TABLE OF CONTENTS

\section{SECTION}

1

2

3

4

5

6
SUMMARY

FUEL ALCOHOL MARKET ASSESSMENT

2.1 General Demand

2.2 Automotive Fuel Demand

2.3 Geothermal Food Processors' Alcohol Fuel Market

2.4 Conclusions

FEEDSTOCK MARKET ASSESSMENT

3.1 General

3.2 Corn

3.3 Barley

ETHANOL BY-PRODUCT MARKET ASSESSMENT

MUSHROOM MARKET ASSESSMENT

5.1 Population

5.2 Production

5.3 Consumption

5.4 Prices

5.5 Other Producers

5.6 Marketing Approach

5.7 Spent Compost

5.8 Conclusion

OPERATING COST AND CASH FLOW ANALYSIS

6.1 Capital Requirements

6.2 Operating Cost and Cash Flow Analys is

6.3 Income Statements and Cash Flow Analysis

6.4 Risk Assessment

PROJECT MANAGEMENT

7.1 Team Organization and Responsibility

7.2 Management Plan

7.3 Project Control

7.4 Plan of Execution

7.5 Project Phase Control

7.6 Reporting

7.7 Key Decision Points 
TABLE OF CONTENTS (continued)

SECTION

8

SUPPORT SERVICES

8.1 Andersen Group, Inc.

8.2 Morrison-Knudsen Company, Inc.

9

PAST CONTRACT PERFORMANCE 
VOLUME III

TABLE OF CONTENTS

SECTION

1

2

3

4

5

6

7

APPENDIX
SUMMARY

EXISTING SITE CHARACTERISTICS AND SOCIOECONOMIC CONSIDERATIONS

2.1 Location

2.2 Surface Features

2.3 Existing Drainage and Runoff Patterns

2.4 Offsite Facilities

2.5 Atmospheric Conditions

2.6 Hydrology

2.7 Geology and Soils

2.8 Ecology

2.9 Aesthetics

2.10 Socioeconomic

PLANT AND PROCESS DESIGN

3.1 Resource Requirements/Resource Production Ethanol Facility

3.2 Resource Requirements/Resource Production Mushroom Facility

3.3 Plant Site

3.4 Offsite Facilities

3.5 Environmental Controls

ENVIRONMENTAL AND SOCIOECONOMIC CONSEQUENCES OF PROJECT

4.1 Consequences of Construction

4.2 Consequences of Operation

FEEDSTOCK TRANSPORTATION

5.1 Logistics

5.2 Environmental Impact

PRODUCT AND BY-PRODUCT TRANSPORTATION

6.1 Logistics

6.2 Environmental Impact

REGULATORY, COMPLIANCE

7.1 Applicable Regulations

7.2 Best Available Control Technology

7.3 Permitting Schedule

ENV IRONMENTAL IMPACT ASSESSMENT EIA/GE/77-5 


\section{SECTION I}

\section{SUMMARY}

This feasibility study report, consisting of this and two additional volumes, was conducted under DOE Grant DE-FG03-80SF11428 during the period October, 1980 through September, 1981.

The report is concerned with the technical and economic viability of constructing and operating two geothermally cascaded facilities, a bio-mass fuel ethanol production facility and a mushroom growing facility, where Geothermal Food Processors presently operates the world's largest directuse geothermal vegetable dehydration facility.

A review and analysis of the data generated from the various project tasks Indicates that existing, state-of-the-art, ethanol production and mushroom growing technologies can be successfully adapted to include the use of geothermal energy. Additionally, a carefully performed assessment of the geothermal reservoir indicates that this resource is capable of supporting the yearly production of 10 million gallons of fuel ethanol and $1.5 \mathrm{milli}$ pounds of mushrooms, in addition to the demands of the dehydration plant. Further, data indicates that the two facilities can be logistically supported from existing agricultural and commerce sources located within economical distances from the geothermal source.

The Nevada facility of Geothermal food Processors is currently the only United States large scale industrlal direct user of geothermal fluids. The vegetable hydration plant, the 160 acre fee title site, and the geothermal resource, were all developed under Title II Geothermal Energy Research \& Development Act of 1974. The facility has pioneered the technology of down-hole well pumping and direct pressurized usage of geothermal brine 
for industrial application. The original binary working fluid system proved unworkable and has been replaced by the "Magmamax" technology of directly using pressurized brine, without heat transfer scaling. Development and first commerclal use of this process was realized at this facility. The plant currently processes about 30 million pounds of onions and celery during its typical 120 day annual operating season.

The process proposed for ethanol production uses proven conventional technology throughout with the exception of mash cooking and spent grains dehydration. Geothermal fluids at $290^{\circ}$ are not suitable for the conventional Unger/Seagram direct steam injection continuous cooking process. This continuous process, 1 icensed by Midwest Solvents through Raphael Katzen Associates, requires 150 psig steam and elevates the cooking process to $350^{\circ} \mathrm{F}$ (ref. R. Katzen et al $1 \mathrm{G}$ rain Motor Fuel Technical and Economic Assessment Study" HCP/T6639-01). The cooking process which would be recommended for the commerclal plant uses newly developed extrusion cooking equipment developed by Wenger Manufacturing, Sa betha, Kansas.

The preliminary assessment of the environmental impact is that it will be negligible to the open space, low vegetation region of the Nevada desert. No significant fossil fuel combustion is involved. Secondary wastewater treatment and impoundment is anticipated. No known endangered species inhabit the site.

The energy factors on a per gallon basis are relatively high but are mitigated by the geothermal source of heat supply. The net result is identical to that of a fossil fueled ethanol plant in that imported and domestic oll 
are directly displaced. In addition, an energy upgrading from an immobile form to a mobile form is realized.

The process proposed for mushroom production uses technology developed and currently utilized in Holland. The growing medium is carefully prepared over a several day period after which it is pasteurized in order to eliminate foreign spores, nematodes, fly eggs, insects, and other organisms. The compost is then conditioned in the pasteurization chambers such that the ammonia present in the compost is converted to protein - this is the food source for the spawns which will grow and be harvested as mushrooms.

The spawn is spread over and mixed with the compost using semi-automatic machinery designed for that purpose. Later the seeded compost is conveyed to incubation rooms where it remains, at opt imum temperature, for 17 days while it matures into spawn capable of growing its mycelium. After the Incubation period the compost is transported to a growing room where, after preparation, a second incubation period will, promote the actual yegetatlye growth. The mushrooms can then be harvested and made ready for the fresh market, or they can be dehydrated in the same way other vegetables are dehydrated in the existing facllity.

By-products of the ethanol plant are distillers concentrated solubles and dried spent grains each of which are separately marketable. Regional markets will adequately support the concentrated solubles volume. Drying of the spent grains is proposed using a horizontal moving belt dryer similar to the existing equipment used for vegetable dehydration. Steam tube dryers commonly used in the older distilling industries are not considered viable for both technical and economic reasons. 


\section{SECTION 2}

\section{BACKGROUND}

\subsection{GEOTHERMAL RESOURCE}

The Brady's Hot Springs Known Geothermal Resource Area (KGRA) has been successfully developed for commercial production of $300^{\circ} \mathrm{F}$ fluids for industrial use. Two producing wells exist and produce geothermal fluids for the industrial vegetable dehydrator at the site.

The technology has been successfully developed at the site and exceptionally low heat transfer surface scaling rates have been demonstrated.

Additional production wells and spent fluid injection wells can be provided to supply the additional energy required for the two new facilities. Extensive hydrological testing and detalled confirmation of the expanded geothermal production field will be necessary prior to plant construction. 


\subsection{GEOTHERMAL FOOD PROCESSORS}

Geothermal Food Processors, Inc., a wholly owned subsidiary of the Andersen Group, presently operates a vegetable dehydration plant at the Brady Hot Springs KGRA. The plant geothermal fluids flow from one of two wells to provide the heat for the dehydration operation. Spent geothermal fluid is presently wasted to the desert surface wetlands. The plant heating system has successfully operated using the "Magmamax" process of down bore well pumping and fluid pressure release after heat exchange. Dissolved calclum bicarbonate and sllica deposition in the heat exchangers has been effectively el iminated through the use of this process. 


\subsection{PRIOR GOVERNMENT SUPPORT}

The vegetable dehydration facility and geothermal resource were privately financed and guaranteed under the Title II, Geothermal Energy Research and Development Act of 1974. The original plant heat exchange design was a dual fluid system in which geothermal fluids were partially flashed and heat exchanged to a clean water working fluid. This process was unsuccessful for production usage due to rapid heat exchanger fouling and major loss of avallable temperature. The process has been modifled to the direct, pressurized, geothermal fluid heating technique known as "Magmamax." Subsequent operation has been highly successful and full design production capacity of the dehydrating facility has been reached on a commerclal scale for three years.

The plant currently dehydrates about 27 million pounds of vegetable products annually and additional products are under consideration which will extend the facility's operating perlod. 


\subsection{RAW MATERIALS AVAILABILITY}

The earlier feasibility study indicated the feedstock of choice is Western barley originating largely in Northern Nevada and the Southern counties of Idaho. 1979 barley production in Idaho was 47,000,000 bushells. The subject ethanol plant annual requirement is 4.7 million bushells.

Nevada production of usable feedstocks, by itself, is inadequate to meet the plant needs. Only 1.3 million bushels of barley is currently produced in the entire state. However, through longer term contracting the amount of acreage dedicated to plant feedstock production could be significantly increased.

The process is, however, designed to use any combination of the feedstocks; barley, corn, cull potatoes, distressed wheat, milo maize, or molasses.

Straw and poultry manure used for mushroom production, are each readily avallable in the Sacramento valley area of California. 


\subsection{TECHNICAL PROCESS AND RISKS - ETHANOL}

Use of geothermal fluids in the low temperature range $\left(300^{\circ} \mathrm{F}\right)$ has not previously been commercialized for fuel ethanol plants. The heat exchange design, however, is technically feasible and has been experimentally demonstrated under previous D.O.E. work at EGEG/Idaho National Engineering Lab (INEL). The technical process preferred is an adaptation of Raphael Katzen/Midwest Solvents technology for geothermal heating. The process is conventional continuous except for batch fermentation. Atmospheric distillation and azeotropic dehydration are required with low temperature geothermal fluids. Cascade energy use in the ethanol process is not presently planned. Cascade use of spent geothermal fluids for spent grains drying may be technically possible and should be analyzed in further work.

Overall process risks are low. The highest risk is probably that associated with further commercial development of the existing geothermal resource. For this reason the first phase of the proposed work deals with drilling additional wells and testing the fluid injection process. All of the resource confirmation work will be completed prior to plant construction. 


\subsection{ECONOMICS}

A detailed analysis of the plant operating costs and cash flows is presented in Section 6, Volume 11. The capital cost breakdown for the project is also presented in this section.

For both plants, with appropriate cost escalations, the cash flow is positive over a 10 year plant life based on the feedstock and input material prices listed in the financial analysis.

Total project capital, including grain storage at Fernley, is estimated at 32.6 million dollars. The grain storage and rail terminal at fernley is estimated at 3.9 million dollars. Working capital is 3.0 million dollars. 


\subsection{THREE PHASE PROGRAM}

A program is separated into three phases corresponding to key decision points. The overall schedule is shown in Figure 2.1 for these phases.

Phase I would (a) confirm the ability to expand the existing geothermal resource through drilling and testing; (b) initiate the environmental review process including submission of required permit applications; and (c) prepare preliminary engineering and process design freezes and analyze the socioeconomic impact in further detail.

Phase II would entail (a) preparation of the detail construction engineering drawings for the mushroom, ethanol and grain storage plants; (b) preparation and contracting for input materials, feedstock acquisition and spent grains marketing, (c) completion of the environmental report; and (d) procurement of long lead equipment terms.

Phase III would involve (a) the completion of procurement; (b) construction of the mushroom, ethanol and grain storage plants; and (c) preparation of the plants and staff for commerclal operation.

The key decision points and reports are:

1. Project contractual authorization.

2. Confirmation of resource and analysis of viability for further commercialization; decision point for Phase 11, (second part of detailed design go-ahead).

3. Design phase completion, permits obtained and final capital cost verified, Decision point for Phase 111 construction go-ahead. 


$$
\text { FIGU } 2.1
$$

OVERVIEW DECISION SCHEDULE

PHASES $1,11,111$

MONTHS

$\begin{array}{lllllllllllllllllllllllllll}2 & 3 & 4 & 5 & 6 & 8 & 8 & 10 & 11 & 12 & 13 & 14 & 15 & 16 & 17 & 18 & 19 & 20 & 21 & 22 & 23 & 24 & 25 & 26 & 27 & 28 & 29\end{array}$

PHASE I

Resource

Confirmation

and Prelimi-

nary Engineering

i

PHASE II

EHSS, Design, $\varepsilon$

Long Lead

Procurement

PHASE 111

Construction

E Start Up

Design Go

Ptart 


\section{SECTION 3}

\section{ETHANOL PRODUCTION FEASIBILITY}

Ethanol production feasibility is thoroughly developed in the feasibility study submitted in satisfaction of grant no. DE-FGOI-80RA50354. Work tasks performed for that study were funded in part by the grant for which this study is written since the scopes of both grants overlap to a large degree. The result of this situation is that, overall, the two complementary reports achieve a far more credible result than would have been possible under one or the other grant, taken by itself. 
SECTION 4

MUSHROOM PRQDUCTION FEASIBILITY

\subsection{OVERVIEW}

This section of the study will investigate, both in general and specific terms, the technical feasibility of a geothermally heated mushroom production facllity, i.e., to determine whether the plant will operate efficiently, reliably, and at reasonable cost. Preliminary design criterla and documentation have been examined to confirm that capital and operating cost projections are reasonable, that mechanical problems will not unexpectedly restrict or halt production, and that, consequently, expected profit margins can be judged reasonably from a technical point of view.

While mushroom growing in the United States has proven successful, both technically and financially, this study proposes to incorporate two modifications to this basic process which makes the project innovative. These modifications are: (1) Use of a semi-automated Dutch growing and harvesting system, and (2) Provision of plant heating and cooling by a direct-use application of cascaded geothermal energy. Numerous Dutch farms have successfully implemented this capital-intensive growing and harvesting system, while direct-use application of geothermal energy Is found at the food dehydration and ethanol production sites discussed elsewhere in this study. This is in all probability the first mushroom growing facility to incorporate both the automated growing system and the use of geothermal energy.

It is not necessary to evaluate the technical feasibillty of mushroom growing, per se; rather, this study will attempt to assess the operating 
reliability of the automated growing system and the geothermal energy system independently. The independence of these two system elements (the success or fallure of one will have no probable effect on the success or fallure of the other) will provide that a favorable evaluation of each will indicate technical feasibllity for the entire project. 


\subsection{AUTOMATED GROWING AND HARVESTING}

As with many agricultural processes, it is possible for mushroom operations to be profitable over a wide range of farm slzes and growing methods.

Interestingly, both large and small farms utilize traditional growing methods, where all phases of the growing operation occur in the same location, the environment is not strlctly regulated, and a large labor force is required to tend and harvest the crop. In recent years, plants have been constructed with capacities ranging from 1 to 12 million pounds annually utilizing newer, more automated growing methods, whlle maintaining stricter environmental control.

Mechanical growing and harvesting in which each of the five phases of mushroom production either takes place in a different location or utilizes different machinery, or both, has been in successful use in Holland and other European countries for some time, and is now finding acceptance in the United States. With use of the semi-automated system, it is possible for each phase of the operation to occur simultaneously, utflizing 10 to 20 percent of the labor force prevlously required. Little or no time is lost during the transition from one phase to another.

The system requires machines which are particular adaptations of materlals-handling and harvesting equipment. The machinery in no way Involves the application of new or "state-of-the-art" technology. As will be described later, production loss is relatively more insensitive 
to machine malfunction under this system, and even this is minimized through a program of preventive maintenance administered by skilled personnel.

The greatest additional advantage of the system is that it allows much greater control of the environment, thus producing greater yields with better quality and more regularlty. Loss due to disease and other uncontrollable factors is reduced. (Yields in Holland are typically more than twice those in the United States.) Since the system is climate-controlled, it is possible to utillze any reasonable location, providing the design of the structure and surfaces, as well as all infrastructure, is adequate. Thus, whlle there is no appreclably greater risk to the grower from utilizing such a system, it actually affords considerable potential for improved yleld and quality over the traditional method. 


\subsection{DIRECT-USE APPLICATION OF GEOTHERMAL ENERGY}

There is no reason to belleve, provided sound geological analysis

is performed and englneering standards are observed, that ut llization of geothermal energy for heating and cooling in the production facility should In any way incur greater risk to the user than the use of conventional energy sources. The opposite will, in fact, hold true in most cases. Barring major earthquakes in the area, the probability of fallure of the heat exchanger or loss of heat to the subterranian water is much less than that of electric power fallure or temporary shortage of fuel oil supplies. 


\subsection{ADDITIONAL USES}

In the event of a dislocation in the mushroom market, or a policy decision to cease mushroom production for other reasons, the growing facllities as they are discussed here could be adapted with little time and expense for use in alternative agricultural processes. These include, but are not limited to: sprouted grain production, onion storage, worm farming, onion and potato dehydration, and soll aid manufacture.

The production of sprouted grain requires large amounts of water and constant control of temperature and humidity. The mushroom growing facillties would remain essentially intact, even to the point of utilization of the growing shelves. Use of the buildings for storage, as in the case of onions, would permit subdivision and mixed use. Given the ability to regulate temperature and humidity in each of the growing rooms, several different processes could go on simultaneously.

Worm farming could utilize the growing rooms, while the tunnel building would evidently be well suited for production of a soll-ald mixture. Only in the case of potato and onion dehydration would major renovation and retrofit be required of the growing and tunnel bulldings. Essentlally all but the structure and walls would be removed and replaced.

It is outside the scope of this study to perform a market analysis for these products. However, it is our opinion that strong markets exist for sprouted grain, worms, and soll aid. The sprouted grain has use both as cattle feed and in processed food for human consumption. 
Worms, in addition to their obvious use as bait, are a necessary ingredient for sewage treatment, land reclamation, and are also use in pet food. Conversion of compost to soll aid, an organic fertilizer, produces roughly a thirty-fold increase in its value. The need for non-chemical fertllizers is well known, as they produce grains and vegetables which are safer and healthier for humans and animals allke.

Some thought has been given to this question; while there has been no serious exploration of the market potential and production problems associated with each of these activities, it appears that these several alternatives to mushroom farming are feasible. 


\subsection{DESIGN ASSESSMENT}

The material in this section will, to the extent possible, provide a basis with which to evaluate the specific design specifications and plans for the mushroom faclilty, as available. The major areas covered by this assessment are: (1) facility bulldings, including HVAC systems, (2) growing and harvesting equipment, and (3) geothermal wells and cascaded heat exchangers.

In many cases, information is insufficlent at the present time to permit a thorough and conclusive review of the design. The design aspects whlch are discussed in detail here are those which were available at the time the report was prepared.

\subsubsection{Facility Buildings and HVAC Systems}

Design of the growing faclilty, with the exception of the heat

exchangers, will involve the following princlpal areas: site preparation and concrete work; structural design; plumbing and electrical design; and HVAC system design. Engineered Structures, principal subcontractor for the effort, and various subcontractors, have worked with our mushroom growing consultant to generate design concepts for the facility; however, in many cases design efforts have not proceeded beyond these preliminary stages.

The lack of design criterla or contract documents containing final plans and specifications for the buildings' structural, electrical, plumbing and mechanical systems makes it essentlally impossible to Investigate the integrity of the design at this time. While it is assumed that all design standards will conform with industry 
code, there is no way of verifying this with the materlals available for review. As an agricultural facllity, the bulldings are exempt from the state code and thus a bullding permit is not required, eliminatIng the need for state review of desIgn plans and specifications.

What information is avallable will be reviewed in the following discussions of specific design areas. Conclusions and recommendations will be presented at the end of this section.

\subsubsection{Site Excavation, Foundations, and Concrete Design}

Engineered Structures and Morrison - Knudsen would be responsible both as designer and contractor for this aspect of the work. Review of concept plans reveals a virtually level site, with soil conditions and bullding configurations requiring only standard foundation and flooring design of the type presently employed in the dehydration facllity - reinforced for mlid earth tremor protection. Work could proceed in conjunction with the structural design, and should produce no problems in either the design or construction phases of the project.

\subsubsection{Structural Design}

Engineered Structures is not a structural design company, and they have consequently recommended the use of a bullding fabricator employing a "pre-engineered structural bullding system." One fabricator capable of handling a project of this type is Anderson steel Buildings Co., Lockford, Callfornia. They would be provided with basic design criterla, such as loadings, bay size, etc., and in turn would perform detalled engineering for the structure, procure and ship the steel to the site and supervise Its erection. Englneered Structures would review the design and reject materlals of interior quality, as necessary. 


\subsubsection{Electrical System Design}

The power requirements for each of the facllity's bulldings are capable of being developed by Bookman \& Womble, GFP's major electrical contractor for the dehydration facillty; however, the working documents showing the power calculations are not avallable. Schematic diagrams for bullding lighting and outlet distribution have been provided by Engineered Structures, but detalled wirlng plans have not been formulated. Since operating requirements for the electrlcal system are straight forward, It is expected that necessary detalled design will be effected as needed. Design and installation of the electrical system, as with site, foundation, and concrete work, should not pose a problem to Engineered Structures.

\subsubsection{Plumbing System Design}

As with the electrical system, only conceptual and schematic drawings are avallable at this time. It is not therefore possible to comment on the acceptabllity of the plumbing scheme other than to indicate that the basic system, as shown, is theoretically operable.

\subsubsection{Growing Racks}

The growing racks intended to hold the beds of compost and casing while the mushroom crops develop have been designed by our mushroom consultant, based on hls experience in Holland and Moses Lake, Washington. These racks are simple in concept, belng nothing more than welded metal shelf frames -- five levels high and approximately 90 feet long. No construction or operation problems should result from the design of these racks. 


\subsubsection{Heating, Ventllating, and Alr Conditioning (HVAC)}

The Gellert Co., a mechanical equipment supply company in the Boise, Idaho area with some design capability, is capable of handing such a project and is a major supplier of environmental control machinery to agricultural users. Its role in the design of the facility would be to determine mechanical equipment needs for bullding alr control -temperature, humidity, and $\mathrm{CO}_{2}$ levels -- and certain other sensing Instruments, such as ammonia probes for the compost, identify appropriate equipment from manufacturers, and supply cost estimates.

The Gellert Company is funded principally with commissions from the manufacturers it orders from, and would charge only a nominal fee for Its design and documentation; detalled design required for the machinery installation is the responsibility of Engineered Structures. Gellert, however, would provide assistance during equipment installation and start-up.

One aspect of a proposed HVAC design which has potential problems is the proposed use of a micro-processor to control all environmental functlons in the growing tunnel bulldings. The intention would be to use a mini-computer to control five environmental functions in 6 tunnel rooms and 16 growing rooms. This would involve receiving cont inuous telemetry information from these 22 rooms, converting the - analog information to digital form, comparing the sensor readings with pre-established norms, and actuating control solenolds or other devices to adjust environmental conditions. Such a system would have to be designed by an electronic company such as GFP's parent, Andersen Group, Inc. 


\subsubsection{Conclusion}

As mentioned earller in this section, the primary basis for ensuring design quality and economy for such a project has been reliance on contractor and consultant reputation. In the context of small to medium sized agricultural projects, this method of operation is not Inapproprlaté. In most cases, the designs wlll be entirely adequate, and a significant cost savings wlll result from use of a design-build firm. 


\subsection{GROWING AND HARVESTING EQUIPMENT}

Current vlews would require the purchase of the required automated growing equipment from two concerns in Holland:

(1) Thilot Machinefabriek, B. V.

(2) Poels Champignonmachine Technlek, B. V.

The following information on each company and the machines they manufacture has been made avallable to the author by our mushroom consultant.

Thilot Company:

(1) The firm has been in business since 1880 .

(2) The firm has built 40 shelfaflliling machines and 30 winches of the type required by the project.

(3) All parts are standard sizes and the majority of them can be found in the U. $S$.

(4) The life of each machine is 3 to 5 years.

(5) Each machine is warranted for 6 months.

(6) The company would supply assistance during machine installation and start-up. This is included in the purchase price.

(7) Customers in the United States Include Oxford Royal In Kelton, Pa,, and Ostrum Mushroom Co. of Olympla, Washington, which has a complete set of machines currently on order.

Poels Champignonmachine:

(1) The company has been in business for 15 years.

(2) Over 550 sets of their machines have been manufactured; however, none of them have been sold In the United States. 
(3) Machine life is estimated at 3 years.

(4) Each machine carries a one-year warranty.

(5) Each machine uses standard parts, most of which can be found in the United States.

Routine maintenance of the Dutch machinery would be done on-site at Brady's Hot Springs. This maintenance would be the responsibility of the existing dehydration equipment maintenance force. Parts not avallable locally can be obtained from Holland by airfrelght, if necessary.

It is apparent that the required Dutch machinery in no way Involves the use of exotic or unrellable technology. Rather, it adapts standard materlals handling Implements -- conveyors, winches, hopper-loaders, etc. -- to a unique set of conditions and dimensions. The designs are evidently proven and tested, which is Impliclt in the companies' warrantees.

The chlef requirements for maintenance then, wlll be a supply of compatible parts, and a mechanic experienced in heavy farm machinery. It is not apparent at this time whether service contracts with the manufacturers could be obtained. However, even if that were possible, it is more than likely that the retalnage costs of such contracts would render them highly cost-Ineffective.

The plan would be for all designated machinery service personnel to obtain and become famlllar with all service documentation from the manufacturers, and that they question company representatives closely on the subject when those representatives are on-s/te for Installation and start-up. Further, there should always be at least two Individuals avallable who are qualified to service the equipment. 


\subsection{HEAT EXCHANGERS}

The heat exchanger is an assembly of plpes suspended in an enclosed chamber through which hot geothermal brine passes (after exiting the dehydration and/or ethanol facilities). Relatively pure water is pumped from the plant to the heat exchanger through one 3-inch pipe and is passed through the heat exchanger in a series of twenty smaller pipes, providing a maximum amount of conductivity between the geothermal water and the plant heating water.

An analysis of the properties of the final design of the heat exchanger will be conducted by Morrison - Knudsen to determine the water flow necessary to provide the required heat to the bullding. It is assumed that the output of this analysis will provide sufficiently accurate and detalled information to ensure the dellvery of hot water to the plant's HVAC system as required.

Total cost for each of the three required heat exchangers, Including labor, is estimated at $\$ 2,500$, The LOKRING sealing system Mechanical Seals Corp.) would be utllized to attach pipes and manifolds. The manifolds themselves would be welded. The task of constructing the three heat exchangers is straightforward, and should pose no problem to construction schedule or future heating system rellability. 


\subsection{CONSTRUCTION MANAGEMENT AND QUALITY CONTROL}

In broad terms, the work required to construct and outfit the proposed mushroom growing facillty will involve the following tasks:
(a) Site excavation
(b) Foundations and concrete
(c) Structural and walls
(d) Heat exchanger installation
(e) Plumbing
(f) Electrical
(g) HVAC
(h) Growing racks
(i) Equipment procurement

Whlle the overall design is simple in concept, the interrelationships between these varlous work elements will require a fairly high degree of sophistication in the areas of construction management and quality control to ensure that the work is completed on time, that budgets are adhered to, and that the facllity operates within the required specifications.

As general contractor, Morrison - Knudsen would be placed under contract to assume responslbillty for managing all aspects of the construction Job. Its management plan detalls how each subcontractor's work would be coordinated and integrated into the total effort. This plan would include a timetable showing the initiation and completion of each phase of the job -- from materials and equipment procurement through site clean-up. 
In addition, Morrison - Knudsen would be given responsibility for the task of growing equlpment procurement. While this task is more Independent than the others, coordination of on-site activities will benefit if Morrison - Knudsen schedules and monitors the procurement of forelgn and American growing equipment. Even if it is deemed not feasible for Morrison - Knudsen to assume direct responsibllity for this task, it is essential that close coordination of efforts be maintained between Morrison - Knudsen and other members of the project who are designated as responsible for the completlon of other tasks.

\subsubsection{Assessment of Need for Backup Heat and Electrlc Power Systems} Fallure of the environmental control system can result from one of three sources: (1) fallure of individual fan motors or pumps within the HVAC system, (2) loss of temperature to geothermal water pool or fallure of the heat exchanger, or (3) electric power failure. The realiability and service needs for the HVAC system have been discussed earlier in this study and will not be included in the present discussion. As mentioned earlier, the probability of a sudden, rapid change in geothermal water temperature occuring is extremely small. Experlence has shown that changes in water temperature occur gradually, indeed almost imperceptibly, giving ample time for contingency plans to be formulated and implemented.

The possibility of electric power fallure does exist. Weather In the Brady's Hot Springs area can be extreme and power outage due to high-wind conditions are presently experienced at the dehydration facility two or three times each operating season. Whlle from a straight probabilistic point of view there appears to be little need for backup heat or power systems, the sensitivity of compost and the mushroom crop to fluctuations in envíronmental indicatórs 
(temperature, humldity, $\mathrm{CO}_{2}$ content) may indlcate otherwise. According to our mushroom growing consultant, significant deviations from normal conditions would begin to cause crop deterioration within as short a time as four hours.

Estimates of the time required to locate, transport, and install a portable boller range from one to two weeks. A portable electric generator could be located more easily, but this would still take from one to two days. It is emphasized that these time estimates are not based on experience, and the actual time required could deviate significantly from that discussed here.

The minimum loss resulting from a total loss of heat for one week's time is on the order of $\$ 125,000$. Loss of heat for two weeks would necessitate a complete new start-up of plant operations, with a total loss approaching $\$ 500,000$. An electric power outage of only a few hours would cause some crop deterloration and result in loss of revenue, though the amount is difficult to estimate.

Conversely, the installation of a backup boller and electric generator, while certainly not Inexpensive, is affordable. It is est Imated that a boller of approprlate capacity would cost approximateIy $\$ 24,000$, In addition there would be intermittent attention required to maintain the boller in operable condition. An estimate of the cost of a standby diesel-powered generator is approximately $\$ 26,000$. Very little maintenance of this machine would be required.

In conclusion, GFP should give serious attention to the investigation of the need for backup heat and power sources for the facllity. This 
judgement is based on the relative sensitivity of mushroom farming to environmental factors, not on a percelved greater risk of fallure of the geothermal energy supply. It is generally concluded that the use of geothermal energy for plant heating and cooling will pose no greater risk of plant fallure and resultant crop loss than conventional systems. Due to the relatively greater malntenance demands of an oilflred boller, It appears that the use of geothermal energy actually poses less of a risk to such a venture. The need for backup heat and power sources should be assessed, regardless of which system is chosen.

\subsubsection{Assessment of Feasibility and Cost of Retrofit}

It is estimated that the cost of retrofitting the facillty with an oll-fired boller is approximately $\$ 30,000$, installed. This boller would be integrated with the hot water ciruclation system at the same point as the heat exchanger. No further modifications of the HVAC system would be required. In addition, we are confident that no facllity down-time would result from installation of this boller, as connections with the existing system could be accomplished in less than one day. There would be minimal disruption to tunnel and growing room environmental conditions.

Installation of this standard heating plant would incur no additional electric power cost. The relative costs of oil and electricity, plus the relative efficlencies of the condensor-chiller units versus electric cooling equipment are such that it would be less expensive, when considering both capltal and operating costs, to continue to cool the bulldings using the chlller unlts. 
Maintenance costs, however, would increase, and the cost of fuel would then become a significant portion of the total operating budget. It is estimated that the current cost of fuel oll needed to meet energy requirements would be approximately $\$ 260,000$ annually.

Natural gas is not avallable at the site, and though accurate prediction is not possible, it is more than llkely that the cost of fuel oll wlll increase at a relatively faster rate than the price of mushrooms even with an increase in the productivity of the operation. With the assumption that little or no increases in productivity are possible, long-range projections of profitability using conventional fuel would show gradual but consistent declines.

Adequate sources of fuel oil supplies have been identified in the Reno/fernley area and there is little doubt that the annual requirement of 450,000 gallons could be met. There is no guarantee, of course, that this supply is uninterruptable. Uncertainties in the national supply of ofl apply everywhere. Two considerations improve the apparent rellability of fuel oll supply, in the event it is needed. The first of these is that agriculture has top priority for oll deliveries when rationing becomes necessary. The second consideration is that retrofit of the facllity with an oll-fired boller would Include the installation of large storage tanks. These tanks would hold a three to four month supply $(100,000$ gallons) and thus the facllity would be relatively immune to short-term disruption of oll supplies. 


\subsection{OPERATIONS}

The material in this section will address selected toplcs which have been Identified as being relevant to the facllity's operation. These topics include:

Sensitivity of facllity operations to equipment malfunction Facllity and equipment maintenance

Packaging operations

Laboratory operations

Disease control

Observations, conclusions and/or recommendations addressed in this section will be considered further when the overall operating budget Is discussed in the Finance section, presented in the Business Feasibility volume.

\subsubsection{Facillty Operations and Equipment Malfunction}

Review of the preliminary plans formulated by our mushroom growing consultant reveals that the facllity wlll operate in continuous, overlapping cycles, whereby each phase of mushroom growing -- composting, pasteurizing, incubation, growing, and harvestIng -- will be on-going simultaneously. The facillty will cycle such that one pair of growing rooms will be harvested and cleared each week, and another pair will be fllled each week. In this way, the crop in each room wlll be at a different stage of development at any given time.

The sensitivity of facillty operations to equipment malfunction, then, is IImIted to that portion of the facillty which is in need 
of the [faulty] equipment at the time it has malfunctioned. For example, the maximum Impact of the fallure of a harvesting machine over a one-week perlod is to prevent the harvesting of two growing rooms. In the same way, the use of six tunnels simultaneously for pasteurization and Incubation will minimize the Impact of the failure of a tunnel cleanout winch, for example, on the supply of incubated compost to the growing rooms.

It is somewhat of a disadvantage that the proposed facility is configured such that it would be difficult for human labor to substitute for machinery. However, this "opportunity cost" of selecting the automated route is not as large as $1 \mathrm{t} \mathrm{might}$ seem, as the realities of recruiting a relatively large labor force over a short period of time with the necessary skills for mushroom production (however simple they might be) are such that it would prove to be extremely costly. The advantage of an efficlent, relatively independent multistage growing system, then, is only partly offset by the difficulty of substituting labor in the event of an emergency. The sum of these two clearly favors the automated. system.

As described earlier, the performance of the forelgn-made equipment has been verified through sales data and manufacturer warranties. GFP plans to maintain on-site repalr facllitles, and provide fulltime personnel who will engage In a program of preventive maintenance. The risk, therefore, of incurring a machine breakdown of more than one week is considered to be very low (though not, of course, impossible). The maximum production loss resulting from a one-week machine fallure would be 3,000 to 4,000 pounds, less than one-half of one percent 
of projected annual production. This figure compares favorably with that for a conventional facllity, where a one-week labor interruption at a critical harvesting perlod would result in losses approaching 5 percent of annual production

\subsubsection{Facility and Equipment Maintenance}

\subsubsection{Cost}

An examination of the cash-flow tables indicates that approximately $\$ 700$ per month has been budgeted for the Item, "Equipment, Auto, Fuel, and Maintenance." of this $\$ 700$, approximately 80 percent has been allocated for fuel. The remaining $\$ 140$ is intended for parts and other supplies for routine and emergency maintenance of the plant's harvesting and growing equipment, Labor costs of maintenance have been included under General Payroll. It is estimated that one trained maintenance person would spend approximately $40 \%$ of his time on routine maintenance.

It is likely that maintenance costs will increase as the age of the equipment increases. This increase has not been reflected in the cash-flow sheets, where maintenance costs are inflated at the same rate as are the other costs. It should be note, however, these maintenance cost projections are not significant in terms of total operating budget and, therefore, should not be a source of concern when evaluating the overall financlal feasibility of the project.

\subsubsection{Labor}

With the exception of the two watermen, who must possess the ability to assume responsibility and work independently, operation of the facillty would require a semi-skllled work force. Plans would call 
for a large proportion of the workers to be able to substitute in different Jobs as the need arlses, especlally in the early phases of start-up. Training for the operation of most machinery would require only a few hours and consequently only a very few workers will be considered indispensable in the short-run.

Training costs are not included in the operating budget, since it would not be realistic to do so. Initlal training would essentially Involve "learning by doing," and therefore there would be no explicit training time or cost. Later substltution of workers, including watermen, would again necessitate on-the-job training. Little or no principal's time would be allocated purely for training purposes, and consequently there is no need to specifically identify training costs.

It is anticipated that the majority of any technical problems which arise with regard to the growing operation Itself would be dealt with by the personnel at the facllity. Approximately $\$ 1,000$ annually has been budgeted for outside consulting. Consultation with regard to the plant, including the geothermal equlpment, does not appear in the standard operating budget. Such consultation can be considered unusual maintenance, and therefore could be treated as a contingency expense.

\subsubsection{Packaging}

Handling of the fraglle mushroom crop will be kept to an absolute mInimum following harvesting. Cut mushrooms will be led by conveyor from the cutting machine directly to 10 lb, cardboard boxes. It is expected that these boxes will not have tops, and wIll store one on top of the other. Note that operating cost estimates do not allow 
for purchases of boxes with tops, and GFP anticipates that any additional cost necessitated by the purchase of boxes with tops will be passed on to the buyer who requested them.

Boxes would be placed on pallets In the work area of the growing bullding. A fork-lift truck would then carry the pallet directly to the cooler bullding for storage at $34^{\circ} \mathrm{F}$ untll pick-up. GFP would provide the labor to onload buyers' trucks, though this should not produce a need for additional manpower as the majority of orders could be loaded in less than 15 minutes.

It is anticipated that most buyers will provide trucks for pickup which are currently backhauling empty or partially empty. GFP would plan to maintain a refrigerator truck for short-haul deliveries in the area: Operating costs of the truck are included in the cashflow analysis. The cooler bullding will accommodate approximately 4 to 5 days production of the facility. Short term irregularities in buyer schedules or problems with weather would, therefore, have only a minimal Impact on lost sales due to crop perishability.

The packaging and distribution system activity appears to be cost efficient. Problems could arise, however, with the task of hand-picking non-acceptable "B" mushrooms from the conveyor before they are deposited in the packaging box, and hand-weighing of the box after it is full. Care wlll be required to ensure that "B" grade mushrooms are not gettlng through and that the packing process is not slowed unnecessarlly. It should also be cautioned that not all buyers will accept mixed $10 \mathrm{Ib}$, assortments in open boxes, and some additional thought must be given to the procedures and costs assoclated with designing and Implementing a more flexible packing operation. 


\subsubsection{Laboratory Operat lons}

GFP would plan to set-up and equip an on-site laboratory for use in product quality testing and possibly for other, yet unspecified, research and development efforts. It is estimated that the total cost for equipment and construction of the lab will be between, $\$ 7,000$ and $\$ 10,000$.

It is understood that commerclal labs are avallable to perform the tests required for mushroom disease and quallty control. The tests are relatively inexpensive, and it would be some three years before the laboratory investment was returned. The only real problem with the use of a commercial lab would be the travel distance -- approximately 47 miles each way.

\subsubsection{Disease Control}

The control of disease is critical to the production of healthy, abundant mushroom crops. Disease has been known to totally cripple a mushroom growing operation. While most problems with disease do not become severe, it is quite possible for disease to cause crop losses of 20 to 30 percent.

A paper on the control of diseases in mushrooms from Penn State University lists 23 different diseases whose effects range in severity from mere discoloration to total crop loss. The overwhelming majority of these diseases are spread by el ther airborne or waterborne means. Several others can be spread through contaminated soll, by insects, or on the hands of mushroom pickers. Careless removal of spent compost can also provide a means by which succeeding crops can be infected by existing pathogens. 
The proposed closed growing system should prove extremely beneficial in the control of mushroom disease. The sealed environment of each individual growing room will be breached only at limited intervals until harvesting. This should effectiveIy reduce the danger of contamination by alrborne and waterborne diseases. Infection by insect-borne disease should also be reduced for the same reasons.

The highly automated nature of the proposed harvesting process should eliminate most danger of spreading contagion through the hands of mushroom pickers. A procedure for insuring worker cleanliness should therefore reduce the threat of human-borne disease to insignificant levels.

Effective management of the proposed growing operation in conjunction with the closed growing room system and automated harvesting, should reduce crop loss from disease to minimal levels. Problems with disease found in conventional mushroom farms would, in large measure, not occur at the GFP facility, and therefore it appears that estimated losses from disease would not exceed 10 percent annually.

It is cautioned, however, that this estimate is not based on an in-depth inquiry Into the subject, but rather a revlew of general conditions and causes. Therefore, the figure quoted should be viewed as an order-of-magnitude estimate, and not as a firm statement of expected loss. 


\section{SECTION 5}

\section{RESERVOIR ASSESSMENT}

\subsection{OVERVIEW}

Extensive testing of the geothermal reservolr in the area of the GFP plant site was performed beginning mid-November, 1980 through midMarch, 1981. The entire test Involved the use of seven existing wells:

$$
\begin{aligned}
& \text { Brady No. } 3 \\
& \text { Brady No. } 8 \\
& \text { Grace No. } 1 \\
& \text { SP No. } 1 \\
& \text { EE No. } 1 \\
& \text { Brady No. } 1 \\
& \text { Brady No. } 4
\end{aligned}
$$

The Brady No. 8 well had been utllized for GFP's yegetable dehydration needs during the six month perlod preceding the test, during which It had been continuously flowed at a rate of 450 to 500 gallons per minute $(\mathrm{gpm})$. The decision was made to monitor the levels in all of the other wells prior to flowing the second well, Grace No. 1, in order to establish the dynamic equillbrium water levels in all of the wells attributable to the flow of Brady No. 8 alone. Beginning November 19, 1980, the water levels in the wells were measured several $t$ imes each day. On December 2, the Grace No. I pump was turned on. Initial flow was about $840 \mathrm{gpm}$ and this slowly increased to 1,000 gpm by December 14, 1980. The pump produced at this rate unt Il January $5,1981$. On that date a leak was discovered in the flowmeter on the well and no further accurate measurement of flow rate was possible. However, 
It is belleved that Grace No. I did flow at about 1,000 gpm during the remainder of the flow test. During the test the pumping of Brady

No. 8 continued uninterrupted, the flow rate declining from 480 to 430 gpm during the flow test period. Both wells were shut in on January 28, 1981. Water levels in all identified wells and temperatures of the produced water from Grace No, 1 and Brady No. 8 were monitored during the entire flow period. Following the flow test, the recovery of water levels in the five observation wells was monitored until March 17, 1981. 


\subsection{DESIGN OF THE WELL TEST}

The design of any well test is constralned by the nature of the given reservolr, status of field development, and nature and completeness of pre-existing data. The constraints at the GFP site Included the following:

1. There are numerous wells in the area. Some were drilled as long ago as the 1960's, and data on some are unavallable or scanty because of a history of proprietary development by different operators.

2. Wells drilled by the predecessors of GFP apparently were not fullytested and some factual details about individual wells (depth, temperature, casing design, etc.) were not avallable or were ambiguous. Most avallable data have been summarlzed by Rudisill (1977) and Rudisill and Dykstra (1979).

3. Several of the oldest wells in the area are now abandoned or Inaccessible. Others are in poor condition. By fleld inspection GeothermEx personnel found five deep wells other than Brady No. 8 and Grace No. 1 usable for an Interference test.

4. Flow rate measurement of the Brady No. 8 well had not been maintained during the period June, 1979 to November, 1980.

5. No rellable record of static water levels in all wells prior to June, 1979 is avallable.

6. Changes in the water levels in all wells in response to flowing and shutting In of Brady No. 8 during the perlod June, 1979 to November, 1980 had not been measured. 
7. Because of the mechanical design of Brady No. 8 and Grace No. 1 wells, there was no practical way to measure the water levels in these two wells while the production pumps were mounted on them.

8. Brady No. 8 could not be shut-in before testing Grace No. 1 because, as of November, 1980, the food dehydration plant was in full operation, hence Grace No. I had to be flowed while Brady No. 8 was also flowing.

9. There had initlally existed some confusion about the nomenclature of some of the wells. GeothermEx personnel Inspected all well sltes in the field and identified them. To avold confusion some wells were given new names for the purpose of this test (Table 1 ). The distances between the key wells were recorded by a tape measure and compared with the existing maps and well records to arrive at the well location map shown in Figure 1. A survey of the relative surface elevation of each well lhead has not been made.

10. In view of the complex geology and geometry of the reservoir, the test results were considered difficult to interpret.

11. A production test of Brady No. 8 had been made previously (Rudisill, 1977); there had also been a test to determine the sultability of well EE No. I for re-injection (Rudisill and Dykstra, 1978).

12. Brady No. 5 suffered a blow-out In June, 1979 and reportedly blew uncontrolled at least unt 11 October, 1979 when it slowly died because of scale deposition. Some data on this blow-out, which caused significant drawdown in the other wells, are avallable In a report by the U.S.G.S. (1979). 
13. No systematic geological, geophysical or geochemical studies on this reservoir exist to facilitate the design and interpretation of well tests.

Within these conditions and constraints it was possible to design a well test program that was operationally feasible and capable of yielding usable reservoir information. Some $1 / \mathrm{m} /$ tat ions substantially increased the amount of effort required to analyze the test data. These limitstrons also precluded the use of certain standard analytical techniques and reduced the amount of information that potentially could have been derived from the test program.

$5-4$ 


\subsection{INSTRUMENTATION AND TEST PROCEDURE}

\subsubsection{Instrumentation of Observation Wells}

Two methods of measuring drawdown or recovery were employed, namely, continuous recording at wells $B$ and EE No. 1 , and electrical sounding of the remaining wells.

The continuous recording instruments were Leupold and Stevens Type $F$ drum chart recorders, coupled with Johnson-Keck DSD-76A digital water level sensing devices. The DSD-76A employs a single-conductor cable with a probe which searches for the water surface under the control of an electronic servomechanism. Electrical continuity is made through the well casing. The device's sensitivity to waters of differing salinity (i.e. conductivity) is adjustable. The cable to the probe passes from its motor-driven reel to and around a pulley which drives

- a mechanical depth gauge (readings in feet and tenths), around the recorder pulley of the Leupold and Stevens instrument, then down the well casing. Access into very small diameter holes is possible because the Johnson-Keck probe is only $1 / 2^{\prime \prime}$ in diameter. This system is also more sensitive to small changes in water level than is a Leupold and Stevens recorder equipped only with a float.

It was not possible to use this instrumentation on continuously bolling wells. An initial Installation on well $A$ had to be abandoned because the servomechanism searched continuously for the bolling water level over a range of $6^{\prime \prime}$ to $12^{\prime \prime}$. The risk of fallure of the motor or gears seemed too great to leave the instrument in the well. Well C also bolls continuously, or flashes with the slightest disturbance, and no such installation was at tempted. 
Well B was successfully Instrumented by sllpping over the probe an 18' length of copper tubing, open at the bottom. This shlelded the tip of the probe from the agitation of the adjacent water surface. At the time the instrument was installed, this well was at the flash point, but not boiling. Contact of the probe assembly with the water surface produced audible bolling which died away after a few minutes, but only when the copper shield was in place. Otherwise, the up-anddown hunting movement of the probe would induce the bolling to continue. Subsequently during the test, the well would sometimes boll spontaneously, causing the probe to go up and down continuously over a range of about I' to $12^{\prime \prime}$ as long as the bolling continued. During one 18-day period of the drawdown test, the well bolled for six to eleven hours each day starting at about the same time (a tidal or barometric effect?) and spontaneously settled down during the intervening perlods. The probe hunted continuously during the bolling perlods, but showed a continuous, steady drawdown whenever the well was qulet. Under these taxing conditions the DSD-76A tool performed well and without interruption save for replacement of the batteries at Interyals of about 3 weeks, and replacement of the probe about half-way through the drawdown test. This became necessary when the original probe apparently became too resistive to function properly because of the formation of sulfides on Its brass surface.

The second well instrumented was EE No. 1, which was not boiling at any time and hence presented no difficulties.

The Leupold and Stevens Type F water level recorder on each well was equipped with an 8-day clock. The recorder on Well B had a $1: 10$ guage scale (.1' equals 1 '); on Well EE No. 1 a $1: 5$ guage scale (.2' equals 1 '). 
Drawdown records on the instrumented wells were maintained both with the Leupold and Stevens recorder charts and through recording at selected time intervals the depth indicated by the digital read-out on the DSD-76A tool, which provided reference points for the depth changes detailed by the charts. The digital depths measured were relied upon more heavily than the charts in reservoir analysis, because the continuous records generally presented more detail than was necessary, and because the periodic readings were sent daily by telephone. The continuous records nevertheless provided information concerning well behavior which would not have been made clear through the use of discrete data alone. During a part of the recovery test the read-out in the DSD-76A tool on well EE No. I falled intermittently, and the recovery curve was subsequently drawn using the continuously recorded charts and occasional electrical soundings. The resulting curve (plate 1) is smoother than curves drawn using periodic measurements, because short-term minor fluctuations were averaged.

Drawdowns in wells $A, C$ and SP No. 1 were measured using a portable well-sounding device manufactured by Powers Company (Fresno, CA), which indicates by needle deflection when bare wires at the end of its two-conductor cable have contacted the water surface. Depths are read from cable markings at five foot intervals. Occasional apparently erroneous readings were attributable in most cases to arithmetic errors made by field personnel in interpolating between the five-foot markers. Readings with the sounder were highly repeatable; accuracy was probably also high, but may have varled slightly with personnel. 
A Soil Test DR-760A water level sounder was also available for measurements. This instrument is analagous in design and function to the Powers sounder, but as the field personnel found it less convenient to use this tool it was employed only during the baseline measurements taken prior to the drawdown test.

The frequency of depth recording at both the sounded and instrumented wells was varied depending on the stage of each test. Initial baseline measurements were started about twelve days before the drawdown test, and made one to four times a day. During the first two days of the drawdown test, depths were recorded at time intervals starting at 20 minutes and increasing to one hour. Subsequently all depths were recorded at four hour intervals. Recovery test depths were recorded every four hours during the first two days, generally every eight hours between the third and fourteenth days, and once a day thereafter.

In addition to the above, periodic soundings were made in two wells at the periphery of the thermal area. One is an unused hot well which is adjacent to the dehydration facility near the highway. The other is a cold well across the highway and southwest of the power substation. Neither well showed any response during the first several weeks of the test and measurements were abandoned; the well at the plant contained much oil which fouled the sounding cable. Small-diameter air lines should be installed in both wells the next time pumps are withdrawn and reinstalled during maintenance, so that depth to water can be measured with a pressure device. 


\subsubsection{Instrumentation of Production Wells}

Drawdown measurements in wells Brady No. 8 and Grace No. 1 were not possible. Neither well had been previously instrumented for drawdown measurement. Rudisill (1977) reported that attempts to insert a sounding cable into Brady No. 8 were unsuccessful so no new attempt was made. Grace No. I has an access tube below the pump motor which is slanted at about thirty degrees (the access on Brady No. 8 is at right angles), but as in Brady No. 8 the clearance between well casing and pump assembly was found to be too small to admit successfully even a sounding cable. Small-diameter air lines should be installed in both wells the next time pumps are withdrawn and reinstalled during maintenance, so that depth to water can be measured with a pressure device.

Rudisill (1977) reported unsuccessful attempts to sound Brady No. 8 with an Echometer, whlch measures the return time of a soundwave. This is not surprising, given the relatively low depth to water even during production, and the restriction of passages down hole by the pump assembly.

Temperature at the wellhead of Grace No. I was measured using a 100$350^{\circ} \mathrm{F}$ dial thermometer installed in the flowllne. Temperature of the Brady No. 8 flow stream was measured at the plant inlet, also with a dial thermometer installed in the flowline. Plant personnel report that past measurements have shown that the drop in temperature between the well head and plant inlet is at most $2^{\circ} \mathrm{F}$ on the coldest winter days. All flow from Brady No. 8 enters the plant; none is diverted. At the time of this test, the pump on Grace No. I had been newly installed, and its flowline discharged into a pit excavated adjacent to the well head. 
The flow rate from Brady No. 8 was measured with a Barton meter installed at the dryer brine discharge. The meter was calibrated from 0 to $1,000 \mathrm{gpm}$, and the smallest division on the chart was $2 \%$ of full scale, which corresponded to $20 \mathrm{gpm}$ at $450 \mathrm{gpm}$. The flow meter was not online until December 5, three days following the start of the drawdown test.

The flow rate from Grace No. I was measured in the discharge line with an annular flowmeter which had a scale reading 300 to $1,000 \mathrm{gpm}$ in divisions of $10 \mathrm{gpm}$. Installation and callbration were complete at the beginning of the test. The measured flow rate climbed steadily during the test and exceeded 1,000 gpm after January 1. On January 6 a leak was discovered in the meter Ilnes and the use of the flow meter was discontinued.

Outlet pressures at a gauge installed upstream of the throttling valve were recorded on a daily basis at each well. The gauge on Grace No. I read 0-200 psi in 2 psi divisions. That on Brady No. 8 read 0-400 psi in 10 psi divisions. Amperage drawn by each pump was recorded daily, from meter scales with $\mathbf{5}$ amp divisions.

\subsubsection{Test Procedure and Personnel}

Instrumentation was installed by GeothermEx and Morrison - Knudsen personnel. GeothermEx personnel spent several days at the slte prior to the drawdown test, installing equipment, demonstrating to supervisory personnel the use and maintenance of the instruments, establishing procedures to be followed during the test, and making baseline measurements. Subsequently, all drawdown records were made and recorded by GFP personnel, with 24-hour-a-day coverage during all of the drawdown test 
and much of the recovery test. The frequency of the various measurements has been reported above. Drawdown in all wells was reported daily, except on weekends, by telephone to GeothermEx's California offices. Temperature, flow rate, pressure and amperage were also reported by telephone. The telephone reports were followed routinely by photocopies of all original field records sent by mail.

At GeothermEx, all data were tabulated and plotted two to three times each week. Drawdown measurements in feet and inches were recalculated as feet and tenths. Where depth measurements made with more than one device were compared and found to differ, as when soundings were used to check the continuous recorders, the reasons for discrepancy were identified, corrections were estimated and applied. These corrections rarely exceeded a few inches and were not significant relative to the water level changes. Routine checks were also made for probable arithmetic or typographic errors in recording, and for questionable data found to be assoclated with records of known or suspected instrument malfunction. These were eliminated.

The total test period lasted about 118 days, including the time spent in making baseline measurements of water levels prlor to the drawdown test. During this time, over 3,000 drawdown measurements were made or recorded. For brevity and simpllclty, a complete listing of these has not been reproduced in this report. Instead, the test data are summarized in a detalled plot of water level, temperature and flow rate versus time, presented as plate 1. 


\subsection{ANALYSIS OF WELL TEST DATA.}

Plate 1 presents the results of the well test conducted at Brady's Hot springs from November 19, 1980 to March 17, 1981. This plate shows the water levels measured in Wells A, B. C, EE No. 1 and SP No. 1 , flow rate from Brady No. 8 and temperatures of the water produced from Brady No. $8(B-8)$ and Grace No. $I(G-1)$ during this period, and the flow rate from G-1 during December 2, 1980 to January 5, 1981. The data show considerable "noise," from various natural causes, the rest being random error in measurement. The accuracy of measurement is on the order of \pm 1 inch of water level for cooler wells and \pm 3 to 6 inches for violently boiling wells (wells A and C). The data were smoothed by visually fitting a smooth curve through the data for analysis reported in this section. This smoothing was satisfactory for the drawdown (flow) part of the test, but the recovery part of the test data could not be easily smoothed.

\subsubsection{Conceptual Basis}

A well interference test usually consists of flowing a well at a fixed rate and observing the change in water level (drawdown) in nearby wells. When the well is shut in, the subsequent recovery of water levels in nearby wells can be monitored. Flgure 2 is a conceptual representation of the various types of reservoir conditions affecting drawdown and recovery testing.

If a reservoir is extremely large in extent compared to the drilled portion it is referred to as an "Infinite system." Figure 2, top, shows the schematic shapes of water levels in such a reservoir. 
The water levels in both the production and observation wells will continue to drop with time as the production well is flowed. Numbers $1,2,3$ in figure 2 indicate the water levels at three different times in the reservoir, 1 denoting the earliest and 3 denoting the latest time. The system never reaches a "steady state" and the water level will continue to drop indefinitely. However, the rate of drop of water level will decline with time. The rate of decline of the level will vary from point to point in the reservoir. This reservoir condition is described as the "transient" state. Theoretically, the change of water level with time in such a system can be calculated. It is shown in figure 3 as a log-log plot of "dimensionless" pressure drop (PD) versus "dimensionless"' time, divided by the square of the "dimensionless" distance of the observation point from the well $\left(t_{D} / r_{D}{ }^{2}\right)$. The symbols are defined in the Nomenclature section. This curve is the Theis curve.

It can be shown that if the actual drawdown observed at an observation well $(\Delta h)$ is plotted versus the time from the start of flow $(t)$ on log-log paper, the resulting plot wlll have the same shape as the Theis curve. However, the plotted data will usually not cover the entire range of the Theis curve shape. The usual practice is to plot observed drawdown versus time on transparent log-log paper to the same scale as the Theis curve and then to overlay the observed data plot on the Theis curve. The transparent plot is then moved up or down, left or right until the observed data plot matches with at least a portion of the Theis curve. During this matching the co-ordinate axes of the Theis curve and the observed data plot must be parallel. 
If such a match is found, the reservoir is behaving as an infinite system for that length of flow period which matches the The is curve. It means that no reservoir boundary has been found during that period of flow. However, it is still possible that the reservolr is not infinite, and that if the flow is continued long enough the data will deviate from the Theis curve, thus indicating a boundary. Once a match between the Theis curve and all or a part of the plotted data are found, one can do a mathematical analysis of the data based on a "match point," i.e., a point on the Theis curve that underlies any specific point on the actual plot. Such mathematical analysis ylelds estimates of the reservoir transmissivity (defined here as $\mathrm{kh} / \mu$ ) and storativity $(\phi c h)$. Transmissivity indicates the ease with which fluids can flow in the reservoir; the higher the value of transmissivity, the greater is the productive capacity of the reservoir. The higher the value of storativity, the higher the fluid reserve per unit acreage. In geothermal reservoirs, kh can range from less than 10,000 to more than a million $\left(10^{6}\right)$ millidarcy feet. Storativity can vary widely (from $10^{-4}$ to $10^{-1} \mathrm{ft} / \mathrm{psi}$.

The middle sketch in figure 2 shows the case of a reservolr with lateral boundaries ("bounded system"). The water level in a bounded system will drop exactly as in the Infinite system until the cone of depression of water level reaches the boundary. This occurs between times 1 and 2 in figure 2. Once the cone has reached the boundary, the rate of decline of water level with time will be constant at all points in the reservoir. This condition is the "pseudo-steady" state. The rate of decline of water level with time during the pseudo-steady 
state can be used to calculate the total fluid reserves in the reservoir. It is obvious that in a truly infinite system, the reserves are infinite. However, often the infinite-acting, or "transient" behavior in the early part of a well test is followed by a pseudosteady state behavior indicating boundaries.

The lowermost sketch in figure 2 shows the case of a "recharged" system. Sometimes a reservoir experiences natural recharge of water by infiltration of precipitation and subsurface flow to the reservoir boundaries, or through a fault conduit, as production starts, If the system is fully rechargable, every gallon of water produced is replaced by natural water influx. In this case the reservolr shows a "steady state," l.e., the water level at any point in the reservoir remains unchanged with time. However, a completely recharged system is rare. Usually a reservoir experiences a partial recharge. In such a case a true "steady state" is never reached. The water level drops with time in this case; however the rate of decline of water level is less than In a corresponding bounded system and the rate of decline of water level will be less as one nears the recharge source. In some cases, the rate of recharge is dependent on the reservolr pressure. As the reservolr pressure declines, the recharge rate increases in such a case. Uitimately, the rate of recharge may exactly balance the rate of production. If that happens, the water level will stop declining, and a steady state will have been reached. As in the case of the bounded system, a recharged system will also go through an initial transient state before the effect of recharge is felt. 
The produced water will eventually decline in temperature if the recharge is due to cold water from the reservoir boundaries. The produced water may actually increase or at least remain constant in temperature if the recharge is due to hot fluids rising from depth through a fault. It is a case of artificial recharge when produced water is injected into the reservoir after use. Injection helps maintain or at least reduce the decline rate of the water level. Injection also helps scavenge heat from the rock matrix and thereby increases the recoverable reserves. Additionally, injection is the best means of disposal of waste water and prevention of ground subsidence due to reservoir voidage.

\subsubsection{Results of Analys is}

The analysis of the test data in this case is complicated by the fact that two wells, not one, have been producing and for different lengths of time. Assuming that $B-8$ had produced long enough to have established a pseudo-steady state, for each observation well the trend of water level decline with time from November 19 to December 2 was extrapolated into the future. Then the difference between this extrapolated water level and the actual observed water level after G-1 started production was plotted versus production time (since December 2) on a log-log plot for each well. Mathematically, this is a method of "de-superposition" of the Influence of Brady No. 8's production from the combined effect of the production of Brady No. 8 and Grace No. 1. The resulting plots were matched to the Thels curve. Figures 4 through 8 show these plots. The data on the match points (arrows) are shown on the plots. Table 2 shows the reservoir parameters calculated from these match points; the theory and assumptions are presented in Appendix A. 
The Thels curve depicts radial flow, i.e., the water flows to the well from all directions. However, in Brady's Hot Springs, it is known that the Brady fault is the main flow conduit from which hot water rises from depth and then spreads out laterally in several layers (figure 9). Hence, a "linear flow" solution (figure 10 and Appendix B) was also applied to the observed data to see if linear flow can provide a closer data match, at least for wells $B$ and $C$ which are known to be very close to the fault. It should be pointed out that this is only an approximation, because the solution assumes a planar, rather than a line, source. Figure 4 shows that the data of EE-1 more closely matches the Theis solution, indicating a radial flow. This is to be expected if it is communicating with $\mathrm{G}-1$ through a reservoir layer and not along the fault. Figure 5 shows that well A seems to match the linear flow solution early-on, then matches the Theis solution. Although no solution exists in the technical literature where a linear flow of this type is followed by radial flow, such a situation is conceivable. The explanation could be that $A$ is near the southern end of the fault and hence the influence of the fault diminishes after a while, following which radial flow exists (figure 5). Figures 11 and 12 show the match of linear flow solution to the data from B and C. After analyzing the data for wells $B$ and $C$, it was felt that the extrapolation of the pre-December 2 water level decline (Extrapolation 1) for these two wells was too steep. Hence a less steep extrapolation (Extrapolation II) was made for each of these two wells and the data reanalyzed (figures 13 and 14). 
Table 2 shows the results of analysis based on the Theis curve only. Table 3 shows the results based on linear flow only, while Appendix $A$ and Appendix $B$ shows the variables for the Theis solution and linear flow solution, respectively. It appears that the wells EE-1, A and SP-1 can be analyzed by the Theis curve and that wells $B$ and $C$ may be analyzed better by linear flow solution. On that basis it appears that wells EE-1, A and SP-1 show infinite-acting behavior, while $B$ and $C$ seem to indicate some recharge, possibly from the Brady fault. It is apparent that $k$ values of the wells are of the same order of magnitude, while ch values are not. This is possibly due to reservoir anisotropy and/or complexity of the reservoir geometry. One must be cautioned that the numbers in tables 2 and 3 are not meant to be accurate estimates but gross approximations of a complex reality. Several attempts to match the observed results by conventional computer matching techniques failed because of the inherent simplistic assumptions in such computer models compared to the reality at Brady's Hot Springs.

\subsubsection{Estimation of Reservoir Capabillty}

The results of well tests indlcate a complex, fault-recharged system with fairly high transmissivity and storativity. There appears to be some indication of recharge from the Brady fault in wells $B$ and $C$. It should be noted that during the flow test the fluid temperature in G-1 gradually increased. This could be due to the heating of the well bore but it is possible that heating of the water may have been due partly to a recharge by hotter fluid from this Brady fault. No wells indicated a boundary during the well test; this could indicate a large reservoir. Thus it is reasonable to describe the Brady's Hot 
Springs resource as a large reservoir fed by hot fluid moving up from depth along a fault. The temperature of water from B-8 is lower than that from $G-1$, because water cools down during its lateral movement from Brady's fault to B-8, which is away from the fault.

The following two questions regarding reservoir capabillty need to be answered:

(1) Is the volume of water stored in the reservoir sufficient to produce $2,400 \mathrm{gpm}$ for at least 15 years?

(2) What will be the drawdown in the reservoir after 15 years of production at $2,400 \mathrm{gpm} ?$

At $2,400 \mathrm{gpm}$, in 15 years about 19 billion gallons of water will be consumed. The stored volume of hot water must be larger than 19 billion gallons to justify the development discussed in this feasibility study. If the waste water from the dehydration, ethanol and mushroom facilities is injected into the reservoir, most of the stored hot water can be recovered. However, if water injection is not practised, a large part of the stored water is not recoverable because of pressure declines. There is no accurate way to calculate the stored water volume in this reservoir. However, crude approximations can be made. Assuming the storativity $(\phi \mathrm{ch})$ values for wells $A, E E-1$ and SP-1 to be representative (table 2), one can calculate the reserves per unit lease acreage. Assuming an effective compressibility of $10 \times 10^{-6} \mathrm{volume} / \mathrm{volume} / \mathrm{ps} i$, and an average $\phi$ ch of 0.05 $\mathrm{ft} / \mathrm{ps} i$ for these wells, the amount of water in place per square mile is 1,000 billion gallons, which is far larger than 19 billion gallons 
needed. Alternatively, $\phi$ hb values for wells $B$ and $C$ (table 3 ) average, around $2 \times 10^{8} \mathrm{ft}^{2}$. Assuming a one-mile long fault zone, the calculated hot water in-place is about 7,400 billion gallons. Thus, the amount of hot water in place in this reservoir is sufficient to supply the proposed need from a fraction of a square mile lease acreage provided waste fluid is injected into the reservoir.

The second question will now be considered. There are several ways to answer this question:

(1) Before flowing G-1, the water levels in wells were declining at the rate of 0.5 to 1.5 feet per month, depending on the well. There was no recognizable decline in SP-1. Assuming an average decline of 1 foot per month, in 15 years a total decline of 180 feet will result from a production rate of $500 \mathrm{gpm}$. If a production rate of $2,400 \mathrm{gpm}$ is used, the total decline in water level in 15 years may amount to as much as 684 feet, which may be too large to allow commerclal pumping of any well. However, this is the most pessimistic extrapolation. The actual declines in water level will be far less because of the following reasons.

1. This extrapolation assumes a pseudo-steady state, which may not be true. If $B-8$ had stlll been undergoing transient flow before G-1 was flowed, the predicted decline would have been much smaller. The minimum decline in 15 years in that case would be about 210 feet (calculated from Thels Solution and $k h$ in table 2).

i1. It is most likely that, as pressure declines, recharge from Brady's fault will be more significant and may help arrest 
water level decline. That is, there may be a slower rate of decline.

ili. Injection of spent water in the reservoir can arrest the water level decline very effectively. If $100 \%$ of the produced water is injected, the water level decline rate will be negligible, the only decline being due to smaller specific volume of cold, injected water compared to hot, original water.

(2) Another way to look at the pressure decline is to notice that the wells were showing a water-level decline rate of about 0.1 feet per day at the end of the drawdown test at a total production rate of $1,500 \mathrm{gpm}(1,000+$ for $\mathrm{G}-1,430$ for $\mathrm{B}-8)$ (January 28 ). If this decline rate continues, assuming a pseudo-steady state has been reached, in 15 years a production rate of $1,500 \mathrm{gpm}$ will cause a water level decline of 547 feet. For a $2,400 \mathrm{gpm}$ rate, the total decline in water level will be on the order of 875 feet, which is similar to the number calculated before. For the reasons outlined previously, the actual decline in water level will be far smaller.

(3) Table 4 and plate 2 show the water levels measured in various wells at various times. It is apparent that as of March 17, 1981, the water level has recovered to within 14 to 17 feet of the level before Brady No. 8 started producing in 1979. Further recovery after March 17 was not recorded. Since production started from Brady No. 8, a total of some 367 million gallons have been produced from this well and G-1. Also an estimated 300 million 
gallons have been lost through blow out of well B-5 from JuneOctober 1979. The estimate of loss by blow out was arrived at by noting that the maximum drawdown in wells during the blow out was about 3.5 times the incremental drawdown obtained in the observation wells by production of $G-1$ for two months. Thus, a total of 667 million gallons have been produced from the reser. voir for a drawdown of less than 17 feet. Thus, a maximum drawdown of 484 feet is possible for 19 billion gallons of production.

Again, as pointed out earlier, the actual decline in water level will be far smaller. However, the large potential drawdowns estimated by the various approximation techniques do point out the overwhelming necessity of injection. The production from the reservoir should be increased by drilling wells that can produce directly from the Brady fault. Injection wells should be drilled away from the producing wells and completed at proper depths. The siting of production and injection wells should be guided by a thorough geoscientific study. If production and injection wells are sited and completed judiciously, no premature pressure decline or cooling of the reservoir should be expected when using a planned rate of $2,400 \mathrm{gpm}$ production for 15 years. 


\subsection{CONCLUSIONS AND RECOMMENDATIONS}

1. The Grace No. 1 well can deliver 1,000 gallons per minute with a reasonably moderate drawdown. We have not experlenced any cavitation and the water level was dropping at a modest rate at the end of a two-month drawdown test.

2. The temperature of water produced from Grace No. 1 during the two months of drawdown testing increased gradually from $302^{\circ}$ to $307^{\circ} \mathrm{F}$; the temperature of water produced by Brady No. 8 has remained constant around $270^{\circ} \mathrm{F}$ since 1979.

3. A combined production rate of about 1,500 gallons per minute from Grace No. 1 and Brady No. 8 wells over a two-month period has not shown any drastic decline in the reservolr water level, and the recovery of water level has been reasonably rapid.

4. The drawdown and buildup behavior of the wells indicate a substantial reservoir, adequate to produce a minimum of 2,400 gallons per minute for an expected plant life of 15 years, provided that:
(a) the production wells are suitably located and judiciously completed based on a thorough geoscientific study.
(b) the waste fluid is injected into the reservoir through care- fully located and completed injection wells.

5. No premature pressure decline or cooling of the reservolr fluid should be expected for a 2,400 gallons per minute total production rate distributed between several wells sited judiciously. 


\section{NOMENCLATURE}

$b=$ Width of fracture, $\mathrm{cm}$

$B=$ Formation volume factor of water, dimensionless

$c, c_{t}=$ Effective compressibility of rock-fluid system, $\mathrm{ps}^{-1}$

$h=$ Net reservoir thickness, $\mathrm{ft}$

$\Delta h=$ Drawdown, ft

$k$ - Absolute permeability, milldarcy

$p=$ Pressure, psia

$\mathrm{p}_{1}=$ Initial reservoir pressure, psla

$P_{D}=$ Dimensionless reservolr pressure

$\Delta p=$ Pressure drop, psi

$\left(P_{D}\right)_{M}=$ Dimensionless pressure at match point, Theis Solution

$\left(P_{D} / x_{D}\right)_{M}=$ Dimensionless variable at match point. Linear Flow Solution

$q=$ Flow rate, stock tank barrels/day

$r=$ Radial distance, ft

$r_{w}=$ Wellbore radius, $f t$

$r_{D}=$ Dimensionless radius

$t=$ Time, hours

$t_{D}=$ Dimensionless time

$\left(t_{D} / r_{D}{ }^{2}\right)_{M}=$ Dimensionless varlable at match point, Theis Solution

$\left(t_{D} / X_{D}{ }^{2}\right) M=$ Dimensionless varlable at match point, Linear Flow Solution

$x=$ Linear distance, $c m$

$x_{D}=$ Dimensionless radial distance

$\mu=$ Water viscosity, centipoise

$\phi=$ Poroslty, dimensionless 


\section{SECTION 6}

COMMERCIAL VIABILITY

\subsection{EXISTING SITE SUITABILITY}

The existing plant site consists of 160 acres of fee title desert land along Interstate 80 , approximately 19 miles east of Fernley, Nevada. The site is currently leased (fifty years) to Geothermal Food Processors by Mrs. Lucy Brady.

The existing site, shown in the aerlal photo has been developed successfully as a vegetable dehydrating facility using geothermal fluids as the heating media under previous geothermal technical assistance including the Geothermal Loan Guarantee Program. The factors which make the site highly desirable for further development as a fuel ethanol and mushroom plant are as follows:

- Existing, commercially proven geothermal resource.

- Proven process for brine management without heat transfer scaling.

- Existing plant administration and labor force.

- Remote desert location with minimum environmental impact.

- Favorable socloeconomic impact to the towns of Fernley and fallon, Nevada. 


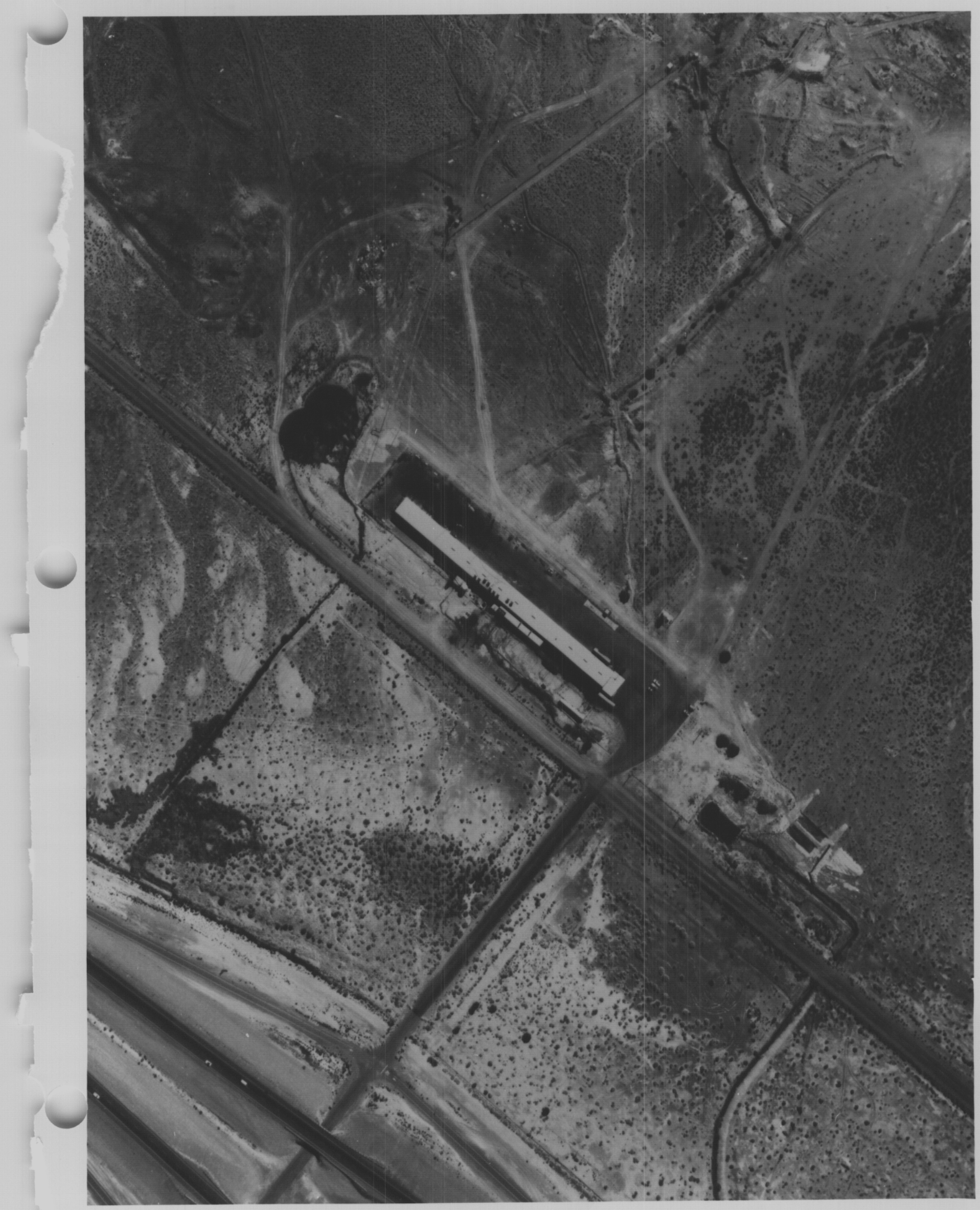




\subsection{RESOURCE BASE}

The existing geothermal resource appears adequate, based on the findings set down at section 5 of this volume to support the required 2400 gpm fluid demand of an ethanol plant and mushroom production facility. Fluid temperatures for existing wells run $270^{\circ} \mathrm{F}$ to $305^{\circ} \mathrm{F}$. Other wells on the leasehold suggest available temperature of $400^{\circ} \mathrm{F} \mathrm{de}-$ pending on location and depth. Two production wells are now fully proven using the latest downhole pumping technology. Only one well is currently used (at $500 \mathrm{gpm}$ ) to serve the existing vegetable dehydration facility. Three additional production wells would be required in order to meet the needs of ethanol and mushroom production. In addition, at least one new deep well is required for spent fluid injection for aquifer recharging.

The ethanol process selected is specifically designed for the low temperature fluids. Direct pressurized brine heating is to be used without flashing and with no pressure reduction untll after the heat exchangers. This technology, known as the "Magmamax" process, is currently used successfully at the existing vegetable dehydration plant.

Feedstock for the ethanol plant will consist primarily of western barley although It should be noted that Nebraska and midwest \#2 feed corn are also economically viable, even after considering transportation costs. The design of the plant will permit use of several feedstocks such as corn, cull potatoes from Nevada, and grain sorghum (milo maize). To accomodate these multiple feedstocks, the cooking 
and mashing unit operation selected is a continuous, enzyme/acid hydrolysis, extrusion process commercially available from Wenger Manufacturing Company.

The process selected is "conventional" in the distilling industry and all operations except mashing are currently in use by Midwest Solvents/RKAll and others. All operations are continuous except batch fermentation. Distillation is conventional and atmospheric. Ethanol dehydration is via azeotropic distillation using benzene or cyclohexane. Distillation bottoms are centrifuged and the thin liquor evaporated to distillers concentrated solubles in a conventional three effect, forced circulation evaporator. Spent grain insolubles are dried without solubles addition on a horizontal belt dehydrator simflar to the equipment now in use for vegetable dehydration. The dehydrator is heated with geothermal brines similar to that now being accomplished in the existing equipment.

Labor resources in the towns of Fallon and Fernley are adequate to supply the plant needs. Special training programs are anticipated for operator and laboratory skills. The existing vegetable plant administration, operation, and maintenance labor force will form the basis for ethanol plant operation. Approximately 60 hourly people will be employed at the ethanol plant for the three shift coverage, operating 330 days per year. An additional 18 people will be employed at the grain storage facility in Fernley, Nevada. 


\subsection{TECHNICAL READINESS}

The ethanol production process is conventional continuous with batch cyclic fermentation. All of the unit operations utilize existing technology already proven in the distilling industry. Each of the unit operations have been commerclalized on, a scale as large or larger than required here except for extrusion mashing and horizontal belt drying of spent grains. These two unit operations, however, do not involve new technology. The extrusion mash cooking process of Wenger Manufacturing, (Figure 6-2) has been used successfully in small scale fuel ethanol plants and has given higher than conventional ethanol yields. Horizontal belt drying technology has been commercialized in the required scale in the dehydration operation at the existing plant. However, the application of the horizontal belt dehydrator has not been used commercially for spent grains dehydration. The dehydrator manufacturers (Proctor and Swartz, et al.) are prepared to test and guarantee the equipment for this application. The dehydration technical risk is diminished by not applying the tacky, viscous, concentrated solubles to the dried product. Concentrated solubles would be separately prepared and sold in a liquid form.

The application of geothermal fluids for direct process heating also is technically ready on a commerclal basis. The INEL Raft River work has successfully demonstrated the application of direct use brine for distillation; the downhole pumping and "Magmamax" process has clearly demonstrated the direct application of geothermal fluids for heating applications at the Brady Hot Springs vegetable dehydrating plant.

The technology fór low temperature, atmospheric column distillation has been in commercial use for about 50 years. Similarly, the azeotropic 
distillation using benzene as the dehydration/azeotrop breaker involves proven technology. Because of the current concern over the health hazard with benzene, cyclohexane would be modeled and tested in the azeotropic distillation design.

Two process licenses are required. The "Magmamax" process is currently under U. S. patent application No. 15175 and requires a license to most users. However, Magma Energy has licensed the use of the process to GFP on a royalty free basis.

Distillation technology and design would be licensed from Raphael Katzen Associates International Inc. of Cincinnatti, Ohio. Dr. Katzen's firm would provide detail design and start-up of the patented sieve tray distillation equipment including azeotropic dehydration. Negotiation of license fees would occur during Phase II of the project. 


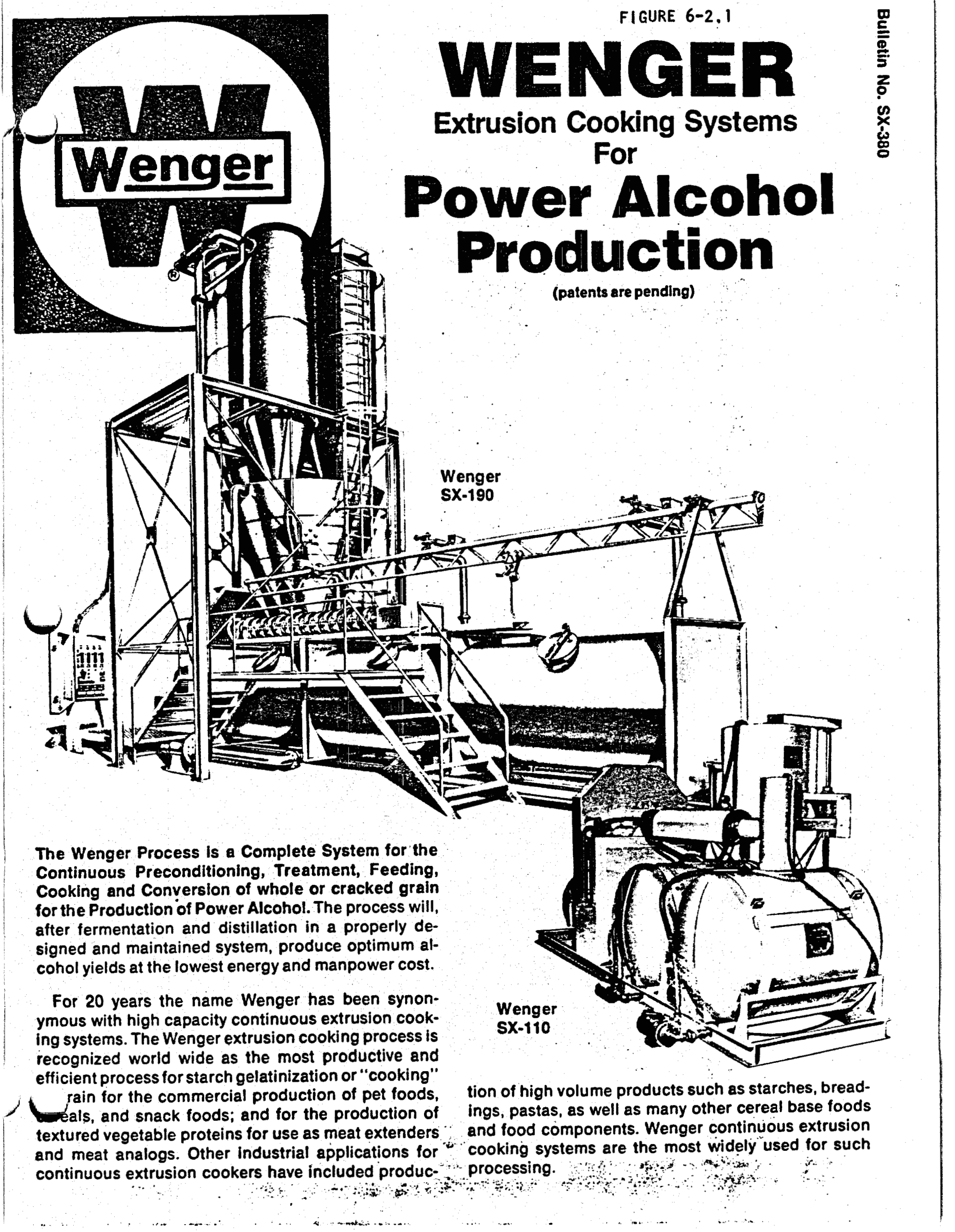


In addition to the $S X-190$ and $S X-110$, Wenger, has developed both larger and smaller ex-

jion cooking systems, designed expressly

the production of power and beverage alcohol. Two industrial model Wenger extruders are available with cooking capacities resulting in yields of 500 to $1000 \mathrm{~g} / \mathrm{h}$ of ethanol.

The Wenger Process is a Complete System for the Continuous Preconditioning, Treatment, Feeding, Cooking and Conversion of Whole or Cracked Cereal Grain for the Production of Power Alcohol.

The Wenger Process makes it practical to use either whole or cracked grain. This results in a) minimum energy being consumed in any preprocessing of the grain, and b) in greatly simplified and more thorough solids removal and recovery from the wet mash.

The Wenger Process alsolends itself well to the utilization of dry milled corn, which permits the removal of the protein before the corn is cooked for ethanol production.

he Wenger Process makes it possible to main. rain (particularly in a continuous fermentation system) the entire alcohol system anaerobic free of any contamination which may retard alcohol yields.

The Wenger Process provides the capability for cooking to established standards and predetermined parameters, thereby assuring con. sistency and quality control of the entire mashing cycle. Alcohol yields become more predictable and more readily optimized.

The Wenger Process makes it possible to produce more alcohol with less manpower, less floor space, less energy consumption, and at less cost.

Future considerations in the cooking, mashing, fermentation, and distillation cycles may include adapting innovative and novel improvements to the existing grain alcohol process. For example, Wenger is experimenting with other types of enzymatic systems, distillation processes, and ancillary equipment used for separation or filtration which may further

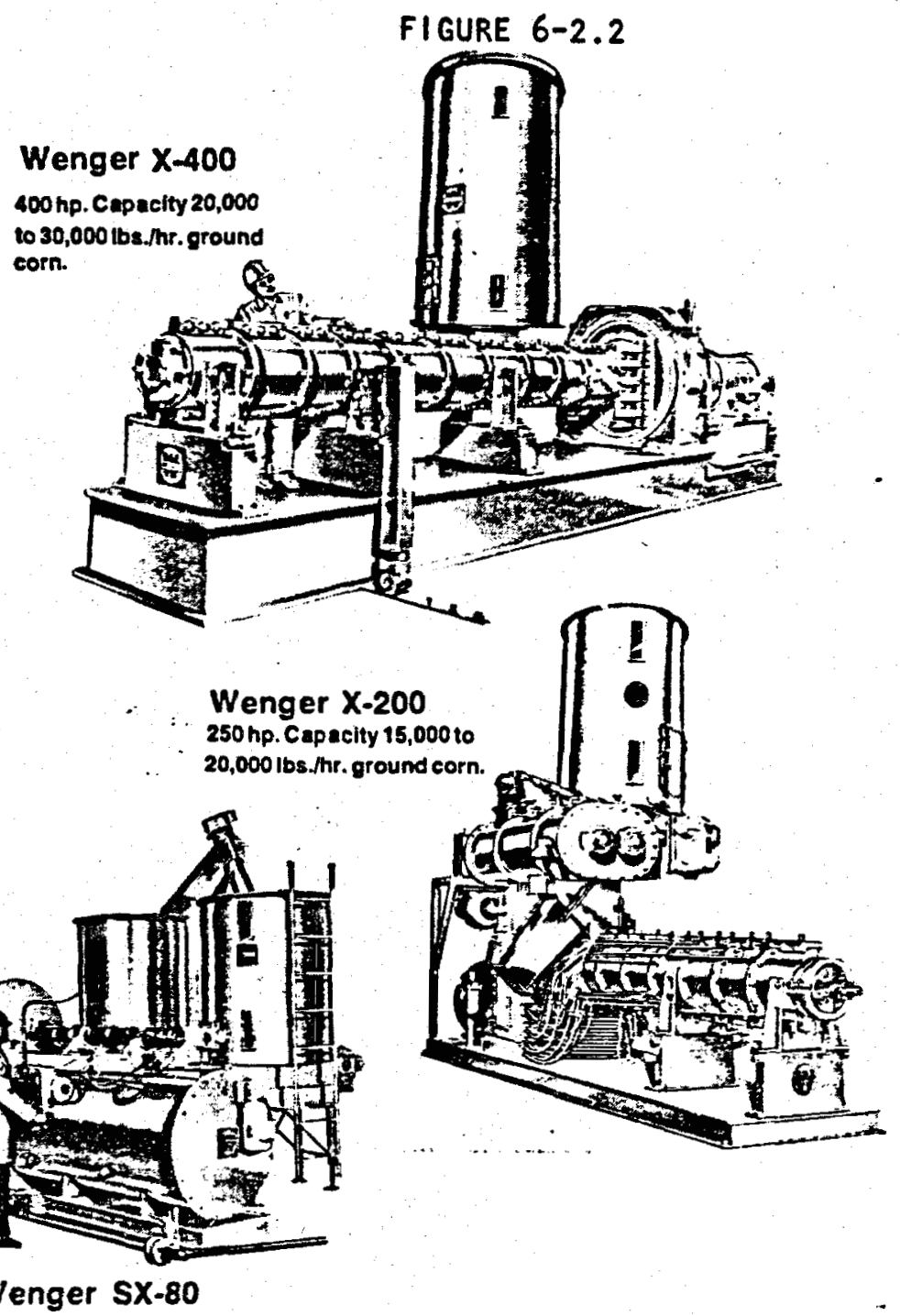

A complete "R\&D" extrusion cooking system, the Wenger SX-80, has been designed for "laboratory" applications. With a cooking capacity of approximately 400 pounds of grain per hour, this unit will complement very well a fermentation/distillation plant with final alcohol yields of 20 gallons per hour. The SX-80 is of stainless steel construction, is fully instrumented, and has been designed to handle a broad range of organic matter. It is a superb research tool for the $R$ \& $D$ group interested in exploring the advantages, versatility, and efficiencies of continuous extrusion cooking for optimizing alcohol yields from a diverse selection of raw materials.

enhance the process and methods employed today.

It has long been Wenger's policy to actively pursue research programs leading to process and product improvements. Towards thls end, Wenger reserves the right to change machine specifications without advance notice.

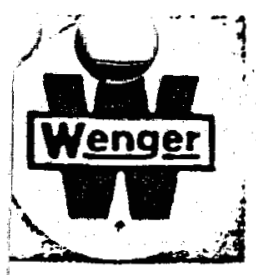

Wenger Manufacturing Plant and General Offices, Sabetha, Kansas 66534, tel. 913/284-2133

Wenger International, Inc. Export Division, One Crown Center, Suite 510, 2400 Pershing Road, Kansas City, Missouri 64108, tel. 816/221-5084, Cable WENGERKCS, telex-42387

Wenger Internatlonal Subsidiary Office, Franklin Rooseveltplaats N. 12, Antwerpen, Belgium; tel (31) 327005, telex 31413 
Cooking of the grain is just one of several preparatory steps in the production of ethyl alcohol. Traditionally, as much as one-half of the total BTU energy requirement (excluding energy for solids separation and by-products drying) is consumed in the "cooking" or mashing cycle. It is this cooking cycle, therefore, that afforded the greatest opportunity for improvement in methodology and reduction in energy consumption and cost. Having specialized in the design and construction of thermally efficient continuous cooking systems for over 20 years, it was in this, the most energy intensive phase of alcohol production, that Wenger decided to concentrate its attention.

The Wenger extrusion cooking systems described here have been expressly engineered to continuously cook and convert grain for the production of alcohol in the most energy efficient manner possible. This Wenger process, when coupled with a properly designed and maintained fermentation and distillation system, will effect a consistent and predictable cook and the starch/sugar conversion to produce optimum alcohol yields at the lowest energy and manpower cost.

Energy costs for cooking and conversion of the grain by the Wenger process (for which patents are now pending) are approximately 2.2 cents per gallon (based on electrical costs of $2.6 c / k w-h r$ ). Total Input energy requirement for a Wenger cooking cycle is as much as $50 \%$ below the BTU requirement for traditional steam let cooking and 60 to $70 \%$ below the energy requitement for conventional extrusion cookers.

The efficiency of any cooking, mashing, and fermentation system is ultimately determined by the ethanol yield, measured in proof gallons per bushel (a term used to denote gallons of 100 proof alcohol yield from one bushel of grain). Laboratory yields have regularly ranged as high as 5.50 proof gallons per bushel on samples of extrusion cooked grain. Typical In-plant commercial processes generally yield 5.2 5.3 proof gallons per bushel $(2.6$ - 2.65 gallons of 200 proof alcohol). 


\subsection{RAW MATERIALS AND BY-PRODUCTS}

For economic reasons, the ethanol process is designed to operate with a variety of feedstocks. The prime feedstock is western barley originating In the growing regions of Idaho, Montana, Nevada and Arizona. Minimum frelght costs are incurred from Southern Idaho and Nevada sources. Idaho ranks fifth in the U.S. with $47,287,800$ bushels (1979) of barley currently being produced in the state. The annual plant requirement will be 4.7 million bushels, constituting only $16 \%$ of the Southern Idaho eastern district production of $30,000,000$ bushels. USDA setaside acreage is about one third million acres. The potential from this set-aside tillable land alone ranges from 18 to $72 \mathrm{million}$ gallons of annual ethanol production.

Nevada's emerging agricultural industry is centered around Winnemucca, Fallon and Fernley. Potatoes, barley, and alfalfa hay are currently produced. Nevada barley production in 1979 was 1.3 million bushels with a potential in existing cultivated land to produce an additional 1.5 million bushels or a total $60 \%$ of the 10 MM GPY ethanol plant needs.

Initial contacts with major grain cooperatives, buyers and elevators have been made. Ample supplies of barley exist throughout Southern Idaho to support this relatively small feedstock requirement. Several cooperatives have expressed a desire to enter into supply agreements when such a project would develop to the design/construction stage.

Transportation of feedstock to the facllity would occur both by truck and rall. Existing main rall service (Southern Paclfic Rallroad) is located approximately 15 miles from the plant site. Our best 
est Imates indicate that a new rail spur from this main line to the plant is prohibitively expensive. As a result, a rall servicing and (25 day) grain storage facility would be planned for an off-plant site in Fernley, Nevada, approximately 19 miles to the west of the existing processing plant on Interstate 80 . Both land and rail sidings exist near Fernley to accomodate an off-site rail/storage facility. Three possible sites are available with rail sidings; each are available by lease from the Southern Pacific Railroad (SPRR). Preliminary discussions with SPRR real estate and Industrial development divisions have been had regarding leasing this land. Cost estimates for the lease and capital for the off-site rall/storage facility are included in the project cost and scope of development work.

Two by-products are produced from ethanol production; concentrated distillers solubles and dried spent grains without solubles. Both products are presently marketed to the western animal feeding industry. Prellminary contacts with P.M.S. Corporation and Pacific Molasses Indicate a capability and desire to absorb all of the by-products into the existing western feed markets. The net market impact to the animal feeding Industry is relatively small since the barley feedstock is now primarily being used for animal feeds and the spent grains and distillers solubles are returned to the same feed markets.

No provisions would be made at this time to collect, compress, and market carbon dioxide. All fermentation carbon dioxide will be vented to the atmosphere.

Total plant wastewater volume is minimized by extensive reuse of condensates and distillation solubles backset. Total wastewater volume is 
$100 \mathrm{gpm}$ average at 1000 B.O.D. Wastewater is screened and then treated for $95 \%$ B.0.D. removal in the cold climate oxidation trench system. Final effluents from both the ethanol plant and mushroom growing facility and the vegetable dehydration plant are to be impounded in a four acre transpiration pond.

Plant fresh water will be obtained from a new well approximately one mile north of the plant site. All fresh water is treated to remove heavy metals and hydrogen sulfide in order to avoid saccharification and fermentation enzyme activity interference.

A summary of input/output material balance information is shown in Tables 6-1 (a) and (b).

$6-8$ 
TABLE 6-1 (a)

MATERIAL QUANTITIES - ETHANOL

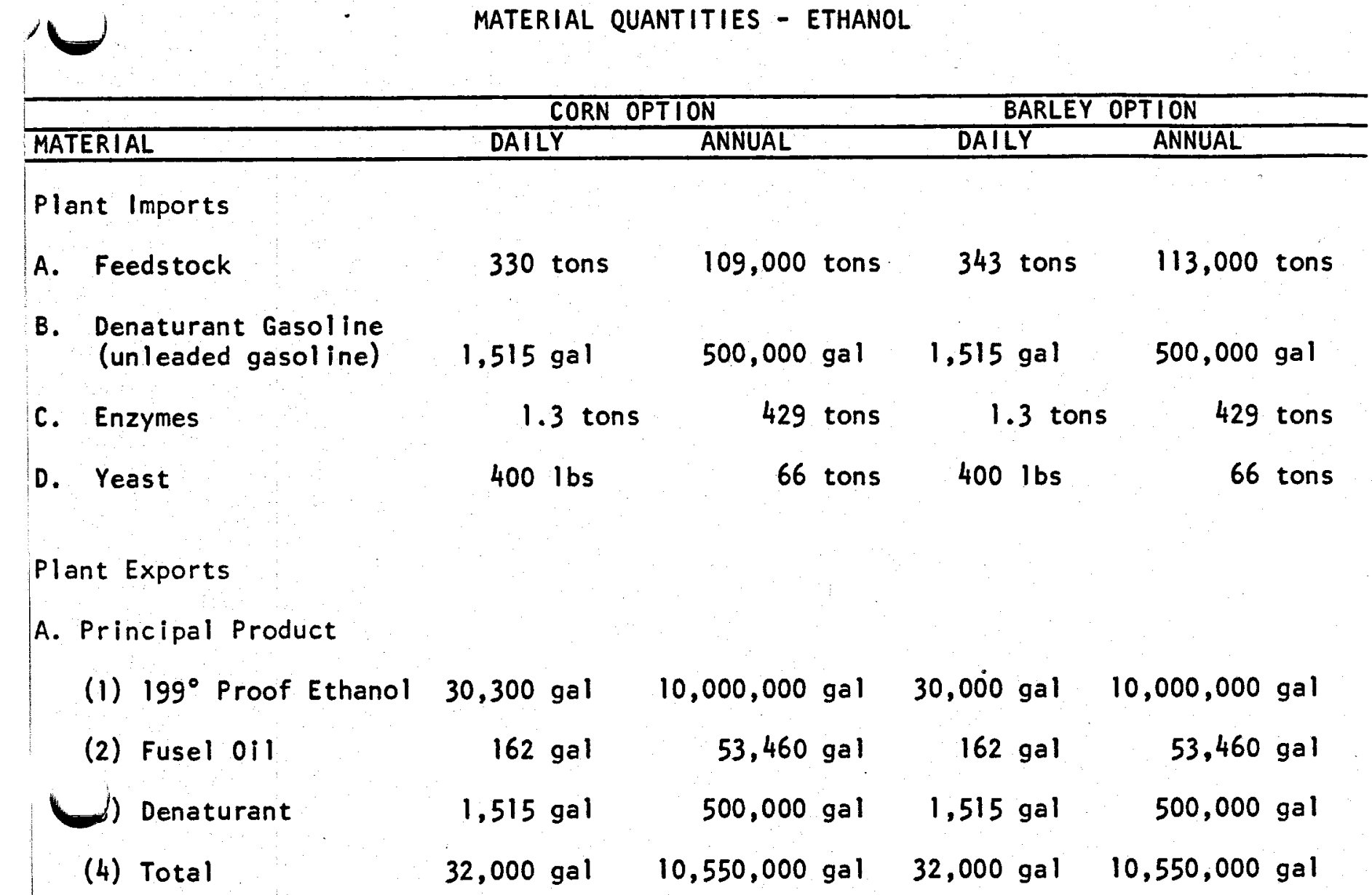

B. By-Products

(1) Concentrated Solubles ( $35 \%$ Solids) 116 tons 38,142 tons 148 tons 49,000 tons

(2) Stillage Cake, Wet* (35\% Solids)

145 tons $\quad 47,850$ tons $\quad 186$ tons $\quad 61,400$ tons

(3) Chaff (Blend with Cake) 3.3 tons

1,089 tons $\quad 3.4$ tons 1,122 tons

*Alternately

Dried Distillers Grains Without Solubles $10 \%$ Moisture

60 tons

19,697 tons

76 tons

25,000 tons

C. Light Ends

1.1 tons

363 tons

1.1 tons

363 tons 
TABLE 6-1 (b)

MATERIAL QUANTITIES - MUSHROOMS

MATERIAL

1. Plant Imports
A. Straw
B. Poultry Manure
c. Peatmoss
D. Gypsum
E. Spawn
F. Boxes

2. Plant Exports

A. Principal Product Mushrooms

$8,007.8$ lbs

By-product - Compost
DAILY (Avg.)

ANNUAL

$\begin{array}{lr}11.2 \text { tons } & 4,100 \text { tons } \\ 11.2 \text { tons } & 4,100 \text { tons } \\ 22.8 \text { bales } & 8,320 \text { bales } \\ 2.2 \text { tons } & 811 \text { tons } \\ 166.7 \text { liters } & 60,8401 \text { iters } \\ 821.9 \text { each } & 300,000 \text { each }\end{array}$

22.8 tons

$2,948,400$ Ibs

8,320 tons 


\subsection{ENERGY BALANCES}

In this section, the heat loads and associated geothermal flows for each of the proposed facilities are presented. In determining the total geothermal flow and cascading possibilities, it is first necessary to identify all the process heat requirements. Table 6-2 lists the major process heat requirements discussed earlier in this report. These values have not been optimized or confirmed and should be considered preliminary.

TABLE 6-2

MAJOR PROCESS HEAT REQUIREMENTS

\begin{tabular}{|c|c|c|c|c|}
\hline Facility & $\begin{array}{l}\text { Heăt Load } \\
\left(10^{6} \text { Btu/hr) }\right.\end{array}$ & $\begin{array}{c}\text { Geothermal } \\
\text { Flow } \\
\text { (gpm) } \\
\end{array}$ & $\begin{array}{c}\text { Inlet } \\
\text { Temperature } \\
\text { Requi rement } \\
\left(O_{\mathrm{F})}\right. \\
\end{array}$ & $\begin{array}{c}\text { Existing } \\
\text { Temperature } \\
\left(O_{F}\right) \\
\end{array}$ \\
\hline $\begin{array}{l}\text { Mushroom farm } \\
\text { Space heating } \\
\text { Space cooling }\end{array}$ & 5.2 & $\begin{array}{l}300 \\
150\end{array}$ & $\begin{array}{l}230 \\
290\end{array}$ & $\begin{array}{l}170 \\
170\end{array}$ \\
\hline $\begin{array}{l}\text { Mushroom Processing } \\
\text { Process heat } \\
\text { Process heat } \\
\text { (alternate) }\end{array}$ & $\begin{array}{l}36.0 \\
36.0\end{array}$ & $\begin{array}{l}600 \\
1200\end{array}$ & $\begin{array}{l}290 \\
230\end{array}$ & $\begin{array}{l}170 \\
170\end{array}$ \\
\hline $\begin{array}{l}\text { Ethanol plant } \\
\text { Saccharification } \\
\text { Steam } \\
\text { Hot water } \\
\text { Distillation } \\
\text { Concentration } \\
\text { Drying }\end{array}$ & $\begin{array}{r}3.1 \\
1.0 \\
33.9 \\
24.0 \\
12.0\end{array}$ & $\begin{array}{r}150 * \\
30 \\
1130 \\
800 \\
400\end{array}$ & $\begin{array}{l}290 \\
290 \\
290 \\
290 \\
230\end{array}$ & $\begin{array}{l}250 \\
230 \\
230 \\
230 \\
170\end{array}$ \\
\hline
\end{tabular}

* Required to produce the necessary amount of $378^{\circ} \mathrm{F}$ steam.

With the heat loads identified, it is possible to determine the total geothermal flow requlrements and the potential areas for cascading the geothermal fluid. Figures $6-3$ and $6-4$ present two potential flow 


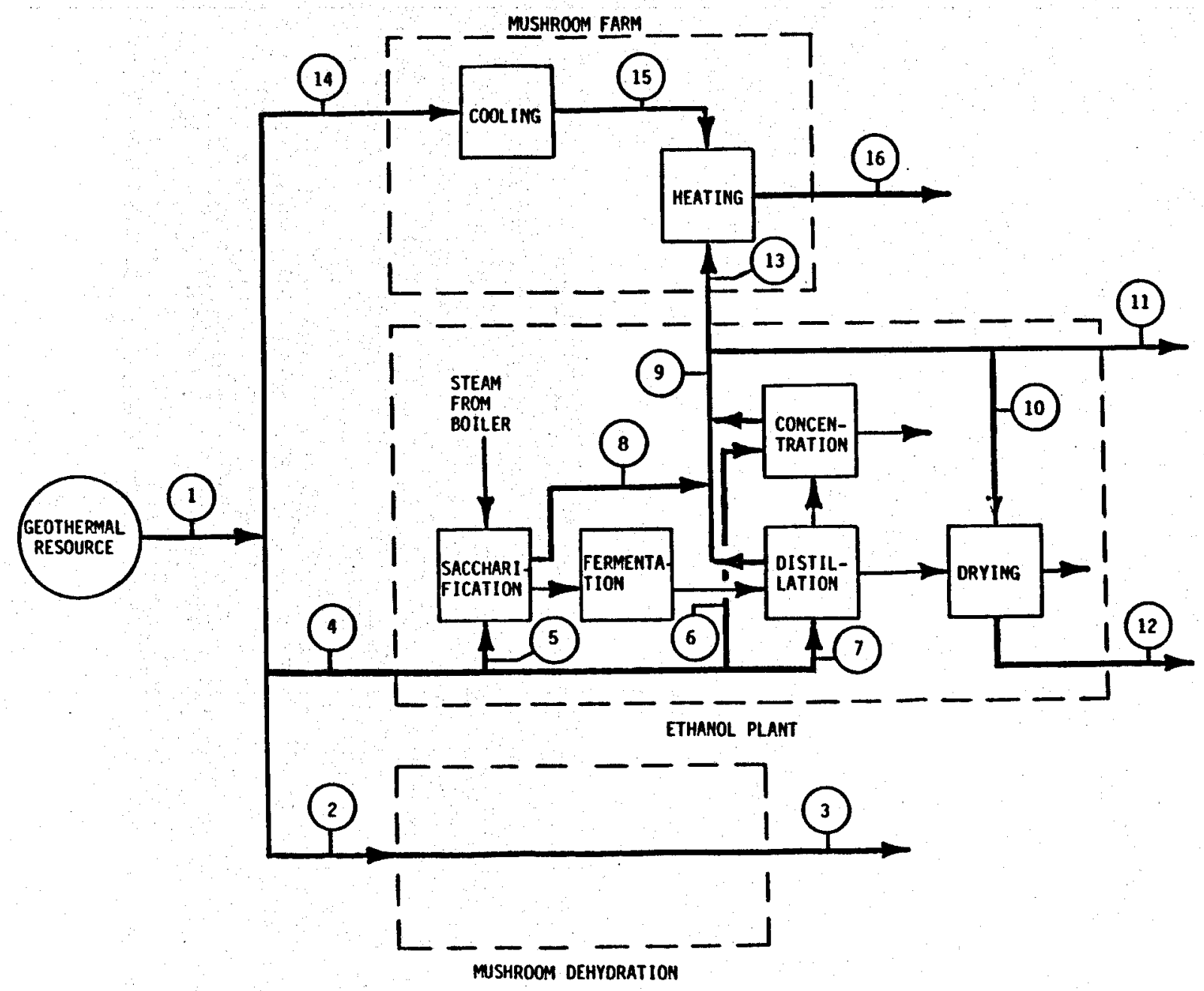

\begin{tabular}{c|c|c|}
\hline STREAM & $\begin{array}{c}\text { FLOW } \\
\text { (gPP) }\end{array}$ & $\begin{array}{c}\text { TEMP } \\
\text { OF }\end{array}$ \\
\hline 1 & 2710 & 290 \\
\hline 2 & 600 & 290 \\
\hline 3 & 600 & 170 \\
\hline 4 & 1960 & 290 \\
\hline 5 & 30 & 290 \\
\hline 6 & 800 & 290 \\
\hline 7 & 1130 & 290 \\
\hline 8 & 30 & 230 \\
\hline 9 & 1960 & 230 \\
\hline 10 & 400 & 230 \\
\hline 11 & 1260 & 230 \\
\hline 12 & 400 & 170 \\
\hline 13 & 300 & 230 \\
\hline 14 & 150 & 290 \\
\hline 15 & 150 & 250 \\
\hline 16 & 450 & 230 \\
\hline
\end{tabular}

Figure 6-3 Geothermal Flow Scheme for the Three Proposed Facilities 


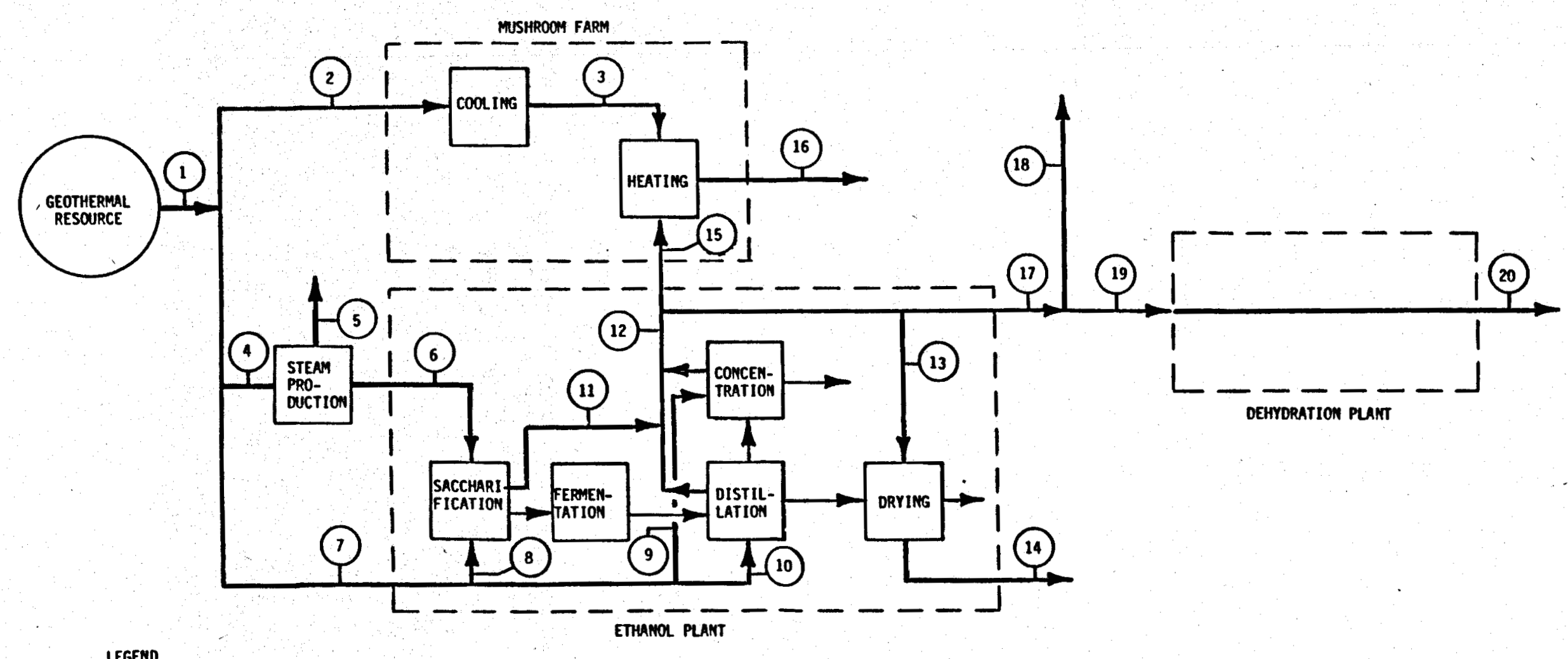

LEGEND

\begin{tabular}{l|c|c|c|c|c|c|c|c|c|c|c|c|c|c|c|c|c|c|c|c} 
STREAM & 1 & 2 & 3 & 4 & 5 & 6 & 7 & 8 & 9 & 10 & 11 & 12 & 13 & 14 & 15 & 16 & 17 & 18 & 19 & 20 \\
\hline $\begin{array}{l}\text { Geotherman } \\
\text { flow (gpm) }\end{array}$ & 2260 & 150 & 150 & 150 & 145 & 5 & 1960 & 30 & 800 & 1130 & 30 & 1960 & 400 & 400 & 300 & 450 & 1260 & 60 & 1200 & 1200 \\
\hline $\begin{array}{l}\text { Tempera ture } \\
\text { FF }\end{array}$ & 290 & 290 & 250 & 290 & 250 & 350 & 290 & 290 & 290 & 290 & 230 & 230 & 230 & 170 & 230 & 200 & 230 & 230 & 230 & 170 \\
\hline
\end{tabular}


schemes. Figure $6-3$ is a conservative case in which little of the cascading potential is utilized. The total geothermal flow requirement is $2700 \mathrm{gpm}$ with a heat load of $114 \times 10^{6} \mathrm{Btu} / \mathrm{hr}$. This 2700 gpm flow would be supplied from three wells based on flow rate capable from the existing wells at the site. Additionally, a boller must be used to provide high pressure steam needed in the ethanol facility. Figure 6-4 illustrates a scheme for utilizing the geothermal flow more efficiently. In this case, the total required geothermal flow rate is reduced to $2250 \mathrm{gpm}$ and the need for an auxiliary boiler has been eliminated. For this second case, $150 \mathrm{gpm}$ of $290^{\circ} \mathrm{F}$ geothermal fluid is used to replace the boller. This is accomplished by flashing the $290^{\circ} \mathrm{F}$ fluid to $250^{\circ} \mathrm{F}$ steam, which is then compressed to produce $378^{\circ} \mathrm{F}$ steam.

It is advantageous to minimize the amount of geothermal fluid extracted from the ground for several important reasons. There is significantly less capital cost involved by reducing the number of wells and the associated piping. The long-term operating costs would also be reduced. Secondly, there is less chance of adversely affecting the resource.

An economic comparison of the two alternatives has not been completed. A comparison of the two alternatives and the base case would have to include both the initlal capital costs and the operating expenses. For the compressor case, the cost of compressor and annual electricity expenses must be weighed against the cost of the boller, annual propane cost, and the additional production well. Only after this comparison is completed can the optimum design be chosen. 


\section{SECTION 7}

REQUIRED WORK TASKS

\subsection{GENERAL SCOPE PHASE I TASKS}

The scope of the required work is to carry the project through construction and start-up in three phases or task groups. Task group 1 is primarily to further develop and confirm added commerclal production of the fluids from the existing geothermal resource. Additional production wells and injection wells are to be drilled and tested; soil tests are to be completed for foundation design; and, the preliminary EHSS review initiated.

The tasks of Phase 1 are as follows:

$1-1.0$ Develop a complete geothermal resource/aquifer model and supervise drilling and fluid injection testing program for new wells

$1-2.0$ Drill (3) new production wells

$1-3.0$ Drill (2) new injection wells

$1-4.0$ Design and install downhope pumps, brine piping, and install substation 1250 kva transformer and electrical connections to pumps

1 - 5.0 Design, fabricate, and install well production test/log equipment and assist testing

1 - 6.0 Prepare preliminary environmental review

1 - 7.0 Prepare socioeconomical review

1 - 8.0 Submit permit applications for air, wastewater, fluid injectlon and plant fuel storage

$1-9.0$ Design wastewater treatment system

1 - 10.0 Phase 1 site equipment

1 - 11.0 Solls testing (Fernley and Brady Hot Springs) 
1 - 12.0 Drill and test domestic water well

1 - 13.0 Project engineering manager - Morrison - Knudsen

1 - 14.0 Project engineering manager - Engineered Structures

1 - 15.0 Program manager - Andersen Group

1 - 16.0 Process finalization

$1-17.0$ Process review and consulting

1 - 18.0 Grain storage facility preliminary site planning and design 


\subsection{GENERAL SCOPE OF PHASE II TASKS}

The scope of Phase 11 tasks is to prepare detalled engineering, construction drawings, secure private capital, develop feedstock commodity contracts, and develop by product, mushroom and ethanol contracts.

Phase 11 tasks for direct work are as follows:

II - 1.0 Develop project management plan

$11-2.0 \quad$ Ethanol plant process englneering and instrumentation design

$11-3.0$ Plant site plan design

II - 4.0 Plant roads, grounds, and foundations design

$11-5.0$ Plant building and structures design

II - 6.0 Plant electrical engineering design

II-7.0 Plant equipment mechanical design

$11-8.0$ Plant process piping design

11-9.0 Plant fire protection system design

$11-10.0$ Plant underground plping design

11 - 11.0 Plant brine piping design

$11-12.0$ Plant wastewater system design

$11-13.0$ Plant cooling tower and process water design

$11-14.0$ Plant potable water system design

$11-15.0$ Plant plumbing, storm sewer, and sanitary sewer design

$11-16.0$ Plant scheduling

11 - 17.0 Plant cost estimating and procurement of long lead items

$11-18.0$ Plant bullding permits

$11-19.0$ Slesmic analysis of structure for zone 4

$11-20.0$ Financial and capital planning

11 - 21.0 Feedstock contracts 
$11-22.0$ Ethanol and by-product marketing

$11-23.0$ Mushroom and by product marketing

$11-24.0$ Grain storage site plan

11 - 25.0. Grain storage roads, grounds, and foundations design

11-26.0 Grain storage buildings and structures design

11-27.0 Grain storage plant equipment mechanical design

$11-28.0$ Grain storage fire protection design

$11-29.0$ Grain storage underground piping design

$11-30.0$ Grain storage plant sewer and water system design

$11-31.0$ Grain storage scheduling

$11-32.0$ Grain storage cost estimating and procurement of long lead items

II - 33.0 Grain storage building permits

$11-34.0$ Grain storage siesmic analysis

11-35.0 Grain storage site lease - S.P.R.R.

11 - 36.0 Grain storage rail siding design

$11-37.0$ Project engineering management

11 - 38.0 Overall program management - Andersen Group

11 - 39.0 Environmental report, ethanol, mushroom and grain storage plants

$11-40.0$ site land survey, ethanol, mushroom and grain storage plants

11 - 41.0 Prepare specifications and contractor bid package for ethanol plant

11 - 42.0 Prepare specifications and contractor bid package for grain storage plant

11- 43.0 Prepare specifications and contractor bid package for mushroom plant

11- 44.0 Distillation system process design

$11-45.0$ Distillation system structural and seismic design 
11- 46.0 Distillation system equipment specifications

$11-47.0$ Distillation system piping design

$11-48.0$ Distillation system plping design

$11-49.0$ Process PEID review and checking

$11-50.0$ Feedstock and agricultural consulting 


\subsection{SCOPE OF PHASE 111 TASKS}

Phase 111 tasks initiate and complete plant construction. Also included is plant start-up and training.

$111-1.0$ Plant construction planning and mobilization

$111-2.0 \quad$ Plant site grading and excavation

1II - 3.0 Plant underground piping and electrical

$111-4.0$ Plant equipment purchasing

III - 5.0 Plant electrical utility supply connection

111 - 6.0 Plant foundation placements

$111-7.0$ Plant process structural erection

$111-8.0$ Plant bullding erection

111 - 9.0 Plant equipment installation

iil - 10.0 Plant piping installation, brine, process, and fire protection

111 - 11.0 Plant electrical Installation

III - 12.0 Plant site paving

$111-13.0$ Plant wastewater treatment

111 - 14.0 Plant final checkout

111 - 15.0 Plant start-up and training

111 - 16.0 Plant clean-up and demobilization

111 - 17.0 Grain storage fachlity construction planning and mobillization

111 - 18.0 Grain storage facllity site grading and rall spur

111 - 19.0 Grain storage faclllty underground sewer and water

III - 20.0 Grain storage facillty electrical utility supply

$111-21.0$ Grain storage facility foundation placements

$111-22.0$ Grain storage facllity bullding and storage silo erection

111 - 23.0 Grain storage facillty equipment Installation 
III - 24,0 Grain storage facillty fire and utility plping

III - 25.0 Grain storage facility electrical installation

III - 26.0 Grain storage facillty site paving

$111-27.0$ Grain storage facility final checkout

111 - 28.0 Grain storage facility start-up and training

$111-29.0$ Grain storage facillty clean-up and demobilization

111 - 30.0 Construction procurement grain storage facillty

111 - 31.0 Construction scheduling ethanol plant, mushroom plant, and grain storage facility

$111-32.0$ Construction procurement ethanol plant

$111-33.0$ Construction procurement mushroom plant

111 - 34.0 Program management

111 - 35.0 Project management

111 - 36.0 Construction management

$111-37.0$ Business/accounting management

111 - 38,0 Process start-up consulting, training, and assistance

111 - 39.0 Human resources planning

$111-40.0$ Geophysical evaluation of production geothermal system performance

$111-41.0$ start-up and operator training 


\subsection{TEAM RESPONSIBILITIES, BY TASK}

The following lists the team responsibilities for the task groups:

\subsubsection{Andersen Group/Geothermal Food Processors}

$$
\begin{aligned}
& 100 \%-1-14.0 \text { Program management, resource development } \\
& 100 \%-11-20.0 \text { Financial and capital planning } \\
& 100 \%-11-21.0 \text { Feedstock contracts } \\
& 70 \%-11-22.0 \text { Ethanol and by-product marketing } \\
& 70 \%-11-23.0 \text { Mushroom and by-product marketing } \\
& 100 \%-11-36.0 \text { Program management, design phase } \\
& 100 \%-111-34.0 \text { Program management, construction phase }
\end{aligned}
$$

\subsubsection{Morrison-Knudsen, Inc.}

$$
\begin{aligned}
& 50 \%-1-4.0 \text { Design and install downhole well pumps, fluid piping } \\
& \text { and electrical } \\
& 90 \%-1-5.0 \text { Design, fabricate, and install well production } \\
& \text { test/log equipment and ass ist testing } \\
& 100 \%-1-7.0 \text { Socioeconomical review } \\
& 100 \%-1-8.0 \text { Preliminary permlt applications } \\
& 10 \%-1-12.0 \text { Drill and test domestic well } \\
& 100 \% \text { - } 1 \text { - } 13.0 \text { Phase } 1 \text { project engineering } \\
& 100 \%-1-15.0 \text { Process finalization } \\
& 100 \%-11-1.0 \text { Through } 11-19 \text { Inclusive detalled design } \\
& 100 \%-11-17.0 \text { Cost estimating and long lead procurement } \\
& 75 \% \text { - } 11-24.0 \text { Grain storage roads, grounds, and foundations } \\
& 100 \% \text { - } 11-33.0 \text { Grain storage siesmic analysis } \\
& 100 \% \text { - } 11-36.0 \text { Project managément } \\
& 100 \%-11-40.0 \text { Specifications and bid package preparation } \\
& 100 \%-111-1.0 \text { Through } 111-16 \text {, inclusive; plant construction }
\end{aligned}
$$




$100 \%-111-34.0$ Project management Phase 111
$100 \%-111-31.0$ Master scheduling
$100 \%-111-32.0$ Construction procurement ethanol plant
$100 \%-111-33.0$ Construction procurement mushroom plant
$100 \%-111-35.0$ Construction management
$100 \%-111-37.0$ Business/accounting management, Phase 111
$100 \%-111-40.0$ Human resources planning

7.4.3 Ag-West, Inc.

$100 \%-1-17.0$ Grain storage facility preliminary site planning
and design
$100 \%-11-23.0$ Through $11-33.0$ plus $11-34.0$, are $11-35.0$
grain storage plant detailed design

7.4 .4 S.E.A., Inc.

$100 \%-1-6.0$ Preliminary environmental review
$100 \%-1-9.0$ Design wastewater treatment system
$100 \%-11.0$ Solls testing ethanol and grain storage plants
$100 \%-11-38.0$ Final environmental report ethanol and grain
$10 \%-11-39.0$ Ltorage plants

7.4.5 Raphael Katzen Assoclates, Inc.

$100 \%-1-16.0$ Process review and consulting $100 \%-11-43.0$ Through $11-46.0$ Distillation detalled design
and siesmic analysis zone A. (Foundations by $M-K)$. 


$$
\begin{aligned}
& 100 \%-11-47.0 \text { Process PEID review and checking } \\
& 100 \%-111-\quad \text { Process start-up training, consulting, and assistance }
\end{aligned}
$$

\subsubsection{Geothermal Food Processors, Inc.}

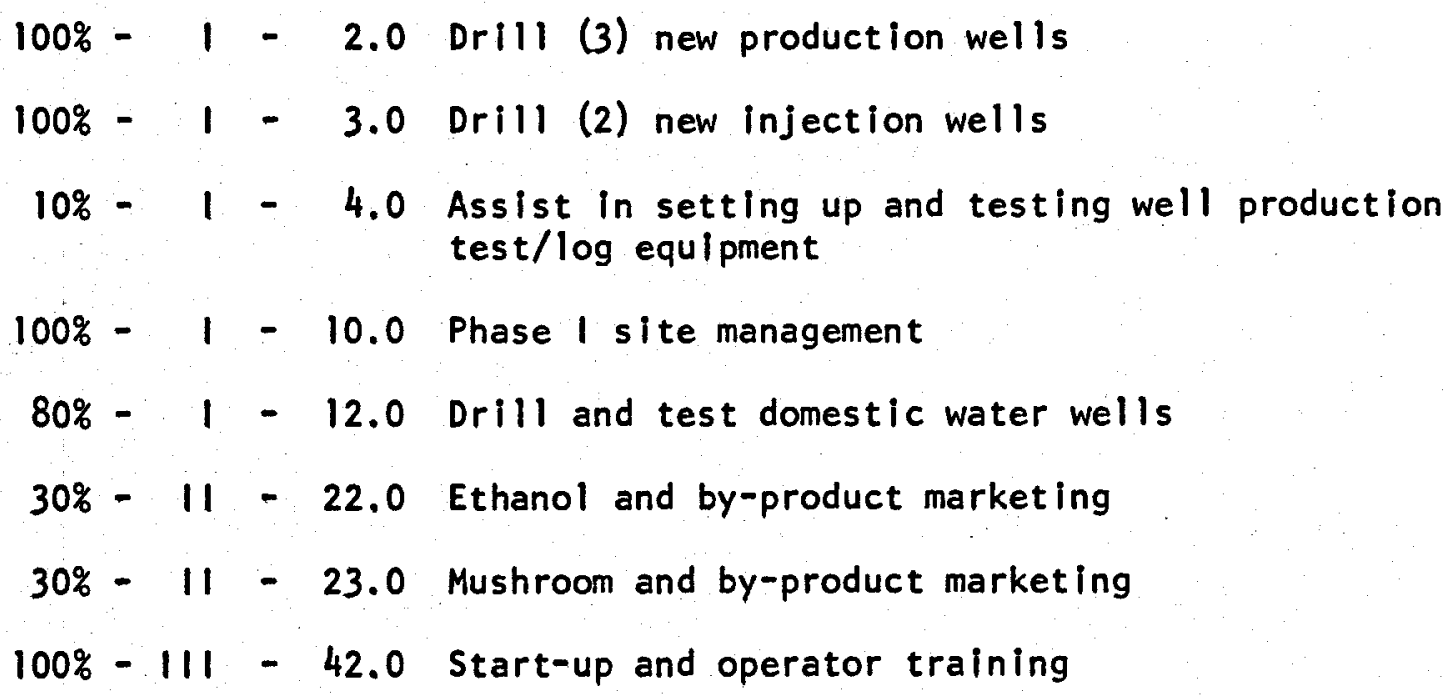

\subsubsection{GeothermEx}

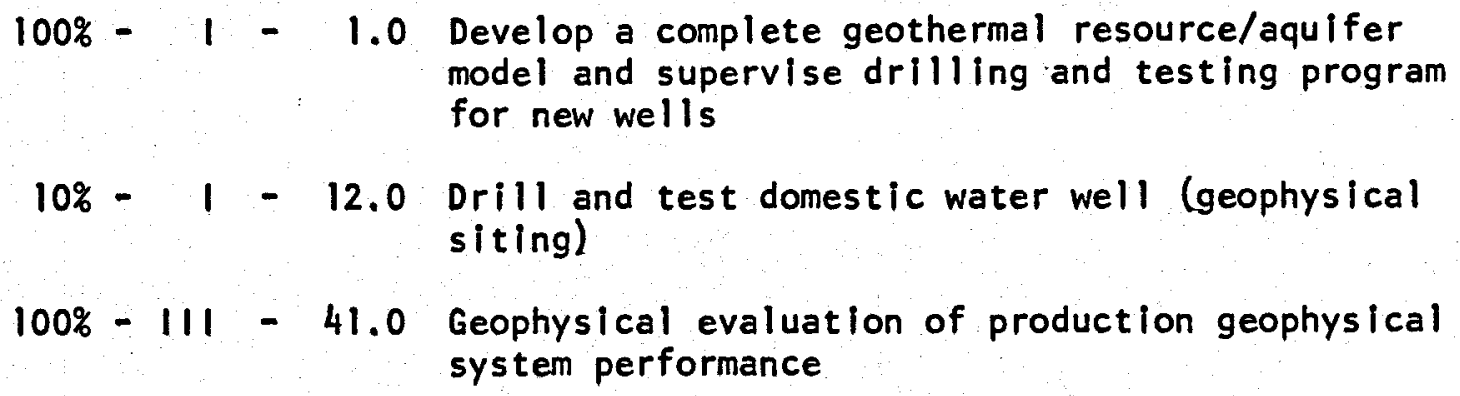

$100 \%$ - $111-41.0$ Geophysical evaluation of production geophysical system performance. 


\section{SECTION 8}

\section{POTENTIAL CONTRACTORS}

\subsection{OVERALL PROGRAM MANAGEMENT-ANDERSEN GROUP, INC.}

Andersen Group, Inc. is a medium size multi-faceted company engaged, through its several subsidiaries, in providing electronics products and services to its customers - with the exception of subsidiary Geothermal Food Processors which, as the company name implies, is in the food processing business.

\section{$\because \cdots$}

The company was founded in Hartford, Connecticut in 1950 as Andersen Laboratories, Inc., and at that time, was engaged solely in the manufacture of quartz delay lines (electronic components) for the military electronics industry.

Over the years the company has grown and branched out in several directions, both by internal growth into non-traditional areas prompted by the Company's diverse technical innovations, and through the acquisition of product lines or companies in complementary areas. The company is presently comprised of the following subsidiaries:

\section{Andersen Laboratorles, Inc.}

This company continues to explore the traditional Andersen product areas centered around the most sophistlcated delay line and electronic support systems technology available. The subs/diary, which is largely engineering oriented, has been, and continues to be at the leading edge of the state of the art in this technical area.

Microtime, Inc.

This subsidiary manufactures (capital) electronic equipment for the video industry and was originally an outgrowth of the delay line subsidiary 
in the early 1970 's. Mlcrotime, enjoys a reputation for being an aggressive innovator in the television industry, having introduced the first commercially viable time base corrector in 1973 with annual model enhancements developed in each of the successive years.

Cardlac Datacorp, Inc.

Cardiac Datacorp provides pacemaker follow-up services to hospitals, physicians and patients, and is currently the largest such service organization in the country. It presently services over 15,000 patients.

Waters Equipment, Inc.

Waters Equipment designs and builds water quality monitoring systems for the electrical power generating industry. Although Waters has perceived a shift in the trend toward nuclear power generation, demands for its equipment have continued their upward movement.

\section{Signal Technology, Limited}

Signal Technology is a company jointly held by Andersen Laboratories, Inc., and the Plessey Company, a multi-national conglomerate headquartered In the U.K. This subsidiary, located in Swindon, England, designs and markets surface acoustic wave delay lines and filters to the European electronics market.

\section{Geothermal Food Processors}

This company is engaged in utilizing Geothermal Resources for varying industrlal applications. Presently the company is the largest U.S. direct user of geothermal energy and is currently actively considering new applications in the area of ethanol production and mushroom cultivation. 
The parent, Andersen Group, Inc., provides the overall management direction and policy making in addition to providing to the subsidiaries such services as (a) finance and accounting, (b) legal, (c) quality assurance, (d) data processing, (e) procurement, (f) public relations, (g) personnel and (h) normal housekeeping functions. 


\subsection{MORRISON-KNUDSEN, INC.}

Morrison-Knudsen Company engages in construction, engineering, design, procurement and project management services on a worldwide basis, primarily on projects in the industrial, heavy and marine, building, power and mining fields.

The Company also operates mines under long-term contracts, develops commercial real estate, remanufactures railroad locomotives and produces a patented door for rallroad ballast cars, assembles and markets electrical generating units for standby power, fabricates steel at a plant in Brazil, holds equity interest in a major Montana coal mine, and co-owns one of the largest shipbuilding firms on the West Coast (National Steel and Shipbuilding Company).

Morrison-Knudsen was founded at Boise, Idaho in 1912 as a builder of the West's early-day dams, canals, railroads and highways. Today, the company is structured into six world-wide market-oriented groups offering full-service capabilities.

The six groups are:

Industrial Group - Staffed with a total complement of more than 1100 engineering, construction and administrative personnel, this group offers the full range of services required for the development of grass-roots mineral processing plants. The group is comprised primarily of the Boise-based Morrison-Knudsen Industrial Division and The H. K. Ferguson Company, a wholly owned Morrison-Knudsen subsidiary with headquarters at Cleveland, Ohio, and other major offices at Akron, Ohio, Houston, Texas, and San Francisco, California. 
Mining Group - A Boise-based group whose 320-man staff includes personnel with wide experience in mine planning, geological and geotechnical applications, engineering, design, construction and operations.

Heavy and Marine Group - Consolidates heavy civil, marine, mechanical, pipeline and underground expertise into a single entity offering a wide range of services in the areas of water resources, transportation, electrical and material transmission systems, marine facilities and government projects other than bulldings. A major source of expertise within this group is International Engineering Company, Inc., a subsidiary of Morrison-Knudsen which has been responsible for more than 350 major engineering projects in 48 countries. The project inventory of "IECO" comprises tallings disposal systems, transportation systems, dams, power plants, transmission lines, irrigation systems, marine facilities, townsites and urban development programs.

Power Group - Offers engineering and construction services for utilities seeking fossil, nuclear refueling, research and development, pollution abatement and environmental control.

Bulldings Group - Comprises long-established capabilities in the areas of commercial, institutional and government buildings and large-scale housing projects.

Manufacturing Speclalties Group - Consolidates responsibility for marketed products of Morrison-Knudsen, most of which are specialty products related directly or indirectly to the company's basic engineering, construction and resources development operations and most of which are designed and built to client specifications. The products include 
locomotive remanufacturing, intermediate and large-scale portable electric operating sets, and fabrication and development of proprietary products for the railroad industry.

Services offered by the six groups are outlined in the following paragraphs. Subsequent sections contain listings of project experience, corporate brochures and other data Illustrating overall capabilities and qualifications of M-K's worldwide team of companies.

Capabilities - Morrison-Knudsen's expertise covers the full spectrum of services, from environmental studies to complete "turnkey" (design/ engineer/procure/construct) projects, both domestically and internationally. Related services include feasibility studies, construction management, operation and support, planning and design/engineering services.

Planning Services - services desired prior to or during engineering and construction - also are among Morrison-Knudsen's capabilities. Morrison-Knudsen provides complete planning services to assist clients in the decision-making process, initial project development, and/or project initiation.

Planning Services include:

- Master planning

- Feasibllity studies

- Environmental studies

- Risk and sensitivity analyses

- Cost and benefit studies

- Development of financing

- Computerized cash flow analys is 
Design/Engineering Services are available from Morrison-Knudsen in all markets served by the organization. Clients are assured of the proper expertise, experlence and competency in virtually every major engineering discipline.

Design/engineering services are available for:

- Industrial plants and processes

- Marine work

- Pipelines

- All facets of heavy civil, mechanical and electrical construction

- Building and housing development

- Mining and mineral resource development

- Power plant facilities

- Manufactured specialty Items

Construction Services - Morrison-Knudsen's construction experience encompasses virtually all types of structures and facllities throughout the world, including civil, industrial and mechanical, as well as training of operations personnel, plant start-up and operation. Additionally, Morrison-Knudsen's services in this field include development, adaptation and fabrication of equipment for specialized applications.

Construction Services are:

- Construction management

- Project management

- Construction

- Turnkey 
Operations - As part of the overall construction effort, technical assistance in planning initlal start-up of a project also is available from Morrison-Knudsen - as long as needed. Morrison-Knudsen works hand-in-hand with clients in planning and preparing operating procedures, recommending adjustments and modifications, and aiding with performance testing. Training of operating and maintenance people is another $M-K$ specialty, or $M-K$ can provide operational services.

Support Services - Morrison-Knudsen has available all the necessary support services to ease difficult project situations and simplify. everyday project concerns. A full range of support services related to construction/engineering is yet another Morrison-Knudsen speciality:

- Project support - estimating, expediting, accounting and payroll

- Procurement of equipment, materials and personnel

- Logistics

- Operations and maintenance - mining, rallroads, and power systems

The Morrison-Knudsen organization is a team of professionals who have performed in every state of th U.S. and in 73 other countries. Experienced and familiar with working conditions from the frigid Arctic to the teeming jungles of Africa and Latin Amerlca - Morrison-Knudsen can design, engineer; procure, construct and manage complex projects anywhere In the world - on schedule and with in budget. 


\subsection{SEA, INC.}

S E A, Inc. was established in 1957 as Sprout Engineers and has since grown to be a multi-disciplinary engineering and planning firm. S E A is a wholly-owned Nevada corporation and operates out of three offices, with its home office in Sparks, Nevada and the other branch offices located in Las Vagas, Nevada and Seattle, Washington. With a professional and support staff of approximately 130 employees, S E A has grown to a present national ranking by the Engineering News Record, of 222 nd among the top 500 architectural/engineering firms in the country. This ranking is quite an accomplishment for a Nevada-based firm and SE A feels it is a clear indication of client satisfaction over the many years we have served Nevadans.

The S E A Board of Directors are working professionals. The engineers on the executive board all hold professional engineering registrations in not only the State of Nevada but also in Callfornia, Arizona, Oregon, Washington, Idaho, Wyoming, and 111 inois.

The S E A Planning group was established at the Sparks, Nevada office in 1970 to compliment the engineering group in providing comprehensive professional services to meet both public and private sector needs. The planning function of SE A has since grown to include a planning division in the Seattle, Washington office. The planning staff in both the Nevada and the Washington offices have very diverse capabilities. Their capabilities range from urban and rural land use planning, transportation planning and economic development planning to landscape archltecture, environmental law, environmental impact report preparation and urban design. Prior to joining SE A, many of the staff had diverse backgrounds, having worked in planning on a varlety of govern- 
mental levels (i.e., State, regional and local) and in other private positions.

S E A, Inc, would assemble a team for this project made up of experienced staff members of its Reno/Sparks office. The following pages describe each individual who would have a major assignment in the proposed studies (soils engineering, waste water treațment, EIS). A brief description of each individual will outline his/her role in work phase of the study and will explain the experience that makes him/her qualified to perform the assignments.

Mr. Martin R. Inouye, Princiapl Planner, would serve as the Project Manager for the proposed studies and would be responsible for the overall management and coordination. He would also serve as the primary liaison with the Morrison-Knudsen Company staff on all three studies.

Mr. Richard Arden, P.E., President of SE A, Inc., would oversee the status and review procedures for the three studies.

Mr. Noel Bonderson, Senior Planner, would act as the EIS project manager, and would have responsibility for overall report preparation and coordination. He would be supported by seven planning staff members. Specifically, he will be responsible for the physical and natural sclence sections.

Ms. Claire Young, Senior Planner, would conduct public service analysis, in addition to overall review of socioeconomic sections; Mr. John Guerin, Staff Planner, would have the responsibility for air 
quality and noise analysis. Mr. Franklin Alverson, P.E. would conduct the traffic analysis and Mr. Joe Murin, P.E. the analysis of impact on any power transmission corridors. Ms. Marta Self, Mr. Joseph Mott, and Mr. Dale Doerr would assist in the preparation of other sections of the report as needed.

Mr. Larry Johnson, Senior Engineering Geologist, would be responsible for the solls engineering analysis. He would be supported by two staff geologists, as indicated on the Work Task Diagram.

Mr. Dal Hunter and Mr. Richard Fink, both staff engineering geologists, would provide data in the solls, topography, seismic, and geologic review of the project, as well as general report preparation.

Mr. George Sevcsik, P.E., Civil Engineer, would be responsible for the wastewater disposal alternative development.

Mr. Watson Ellis, P.E., Civil Engineer, would be responsible for water supply and water quality analysis. He would be supported by Mr. David Peterson, hydrologist, in the preparation of the water/wastewater report. 


\subsection{AG WEST, INC.}

Ag West, Inc. was founded in 1971 In Davis, Callfornia, as an agricultural business and financial management consulting firm. In its early days, Ag West, Inc. primarily served large corporate farms, banks, insurance companies and non-resident land owners with the dayto-day management of agricultural lands.

Early in 1976, Ag West, Inc, was purchased by the present owner and the firm expanded it sprofessional services to include agricultural engineering, farmstead planning, irrigation/drainage system design and turnkey land development. Ag West's services were also expanded to provide internatlonal agri-buslness management, working in Spain, Libya and Egypt.

In October, 1978, the firm moved to Sacramento, California, and further diversified its professional services. Ag West, Inc. currently offers management and engineering services in the highly specialized areas of surface-mined land reclamation, remote-sensing (land satellite) photo interpretation of agricultural land use, silvicultural engineering, reforestration systems, and agricultural/feedstock feasibility assessment for fuel ethanol plants. Also, Ag West, Inc. is currently establishing Ag West Industries as a research and development engineering and special application machinery manufacturing division. Thus we will provide our client complete solutions for their problems, from concept design to mechanized system.

Ag West, Inc. provides professional service to clients throughout California Including San Diego, Orange, Los Angeles, and Ventura 
Counties. Our seryice also extends to current clients in Washington, Oregon, Idaho, Utah, Spain and the Middle East.

Ag West, Inc.'s Consulting and Service Capabilities are in three major divisions:

1. Agricultural Business Management
(a) Farm management
(b) Agricultural land reclamation and development
(c) Agricultural economic analysis
(d) Irrigation/drainage engineering
(e) Soll and water analysis
(f) Landsat (Satellite) photo evaluation of agricultural land
(g) Agricultural commodities consulting

11. Agricultural and Forestry/Silvicultural Engineering and Equipment Manufacturing
(a) Research and development of agricultural and forestry machinery
(b) Design of conifer seedling nursery
(c) Research and development of greenhouse material handling system
(d) Engineering and design of conifer seed extractory facilities
(e) Design and sale of grain handling storage facilities

111. Industrial and Food Processing Engineering
(a) Facility engineering for wineries
(b) Engineering and construction management for a tomato paste cannery
(c) Participation in design of fuel grade ethanol plants 
8.5 RAPHAEL KATZEN ASSOCIATES INTERNATIONAL, INC. (RKAII)

Raphael Katzen Associates International, Inc. (RKAII) has been engaged in design, startup and improvement of fermentation and synthetic alcohol plants for 26 years. Prior to that, some of thelr principals were involved in production and engineering of plants for methanol and ethanol for 16 years, a total of 42 years of alcohol production technology. The DOE report for grain alcohol fuel, prepared by RKAII, established the technical and economic acceptance for production of motor fuel grade alcohol from graln using the most advanced and proven technology avallable at that time. Since 1978, they have been very active in evaluating newer technology and incorporating this into the design of economical and energy efficient process designs.

RKAII is one of the most experienced companies in the area of alcohol technology in the world today. Countries such as Brazil, Cuba, Poland and many others, have used or are in the process of using RKAll technology. Dr. Katzen was Instrumental In assisting Cuba with a Gasohol (15\% MFG alcohol) program from 1950 to 1960. RKAll technology was used in the areas of molasses pretreatment, fermentation and distlllation. 


\subsection{GEOTHERMEX, INC.}

GeothermEx, Inc., a small business concern, is a group of earth scientists and engineers providing service and expertise in geothermal exploration and development, in the United States and elsewhere. Since being founded in 1973, GeothermEx has grown to include nearly a dozen senior professional staff members, plus an equal number of junior technical staff, assoclated specialists and non-professional staff. Its clients include electric utilities, major and independent oll companies, small and major landowners, agencles of federal, state and local government, foreign governments, research institutes, engineerIng companies, and major energy consumers looking for al ternative sources.

GeothermEx is able to offer the full spectrum of services from preliminary prospect reconnaissance through the testing of geothermal wells and reservoir analysis. It is able to work constructively with regulatory agencies, environmental groups, drilling contractors, and design and construction engineers.

Its work includes:

- Identification of prospective geothermal areas

- reconnaissance prospect evaluation

- geologic mapping and photogeology

- geochemical field surveys

- hydrologic studies and well inventories

- temperature gradient and heat flow surveys

- gravimetry

- Interpretation of geoelectrical data 
- seismicity and microseismicity studies

- management of exploration

- planning and supervision of drilling

- well logging and log interpretation

- well testing and reservoir analysis

- development planning

- reservoir geochemistry 


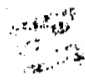

APPENDIX A

CALCULATIONS USING THEIS SOLUTION 
Assumptions for Theis Solution:

(1) Horizontal, radial flow

(2) Negligible gravity effects

(3) Homogeneous and isotropic porous medium

(4) Single fluid phase of small and constant compressibility

(5) Darcy's law applies

(6) $\mu, c, k$ and $\phi$ are independent of pressure

(7) Constant flow rate from a line source

(B) Infinite radial system

Theis Solution:

(Earlougher, 1977)

$$
\begin{aligned}
& P_{D}\left(r_{D}, t_{D}\right)=-1 / 2 E 1\left(-r_{D}{ }^{2} / 4 t_{D}\right) \\
& \text { (solution graphically shown in figure } 3 \text { ) }
\end{aligned}
$$

Where $D_{D}=\frac{k h\left(D_{i}-p(t, r)\right)}{141.2 q B_{\mu}} \quad$ (assuming no skin effect)

$$
\begin{aligned}
& r_{D}=r / r_{w} \\
& t_{D}=0.0002637 \mathrm{kt} / \phi \mu c_{t} r_{w}^{2} \\
& E j=\text { Exponential integral, defined as } \\
& E i(-x)=-\int_{x}^{\infty}\left(e^{-u} / u\right) d u
\end{aligned}
$$


Calculation of Parameters:

From match points, transmissivity $(\mathrm{kh} / \mu)$ and storativity ( $\phi \mathrm{ch})$ are calculated as follows:

$$
\begin{aligned}
\log \left(D_{D}\right)_{M} & =\log (k h / 141.2 q B M)+\log (\Delta P)_{M} \\
\text { and } & \log \left(t_{D}\right)=\log \left(0.0002637 k / \phi \mu c r_{W}{ }^{2}\right)+\log t_{M^{\prime}}
\end{aligned}
$$

Where $\left(P_{D}\right)_{M}$ and $\left(t_{D}\right)_{M}$ are the dimensioniess pressure and time, respectively, of the match points and $(\Delta P)_{M}$ and $t_{M}$ are the corresponding real pressure drop and time, respectively.

The following average values of the various parameters were assumed for the Brady's Hot Springs area:
Reservoir temperature $=325^{\circ} \mathrm{F}$
Flow rate (Grace 1 only) $=1,000$ gallons per minute
Viscosity of water $=0.17$ centipoise
Average pressure gradient of water column $=0.4 \mathrm{psi} / \mathrm{ft}$
Formation volume factor $=1.08$
Distances between wells - figure 1 
APPENDIX B

CALCULATIONS USING LINEAR FLOW SOLUTION 
CALCULATIONS USING LINEAR FLOW SOLUTION

Assumptions for Linear Solution:

(1) Horizontal, linear flow

(2) Negligible gravity effects

(3) Homogeneous and isotropic porous medium

(4) Single fluid phase of small and constant compressibility

(5) Darcy's law applies

(6) $\mu, c, k$ and $\phi$ are independent of pressure

(7) Constant flow rate from a planar source

(8) Infinite linear system

Linear Flow Solution:

(Miller, 1962)

$$
\begin{gathered}
\frac{P_{D}}{x_{D}}=2 \sqrt{\frac{t_{D}}{\pi x_{D}^{2}} \exp \left(-\frac{x_{D}^{2}}{4 t_{D}}\right)-\operatorname{erfc}\left(\frac{x_{D}}{2 t_{D} 1 / 2}\right)} \\
\text { for } x_{D}>0
\end{gathered}
$$

(Solution graphically shown in figure 10)

Where $p_{D}=\frac{k h}{q \mu}\left(p_{i}-p(x, t)\right)$

$$
\begin{aligned}
x_{D} & =x / b \\
t_{D} & =k t / \phi \mu c_{t} b^{2} \\
\operatorname{erfc}(x) & =1-\operatorname{erf}(x), \text { where erf }(x) \text { is the Error Function, } \\
& \text { defined as: } \\
& \operatorname{erf}(x)=\frac{2}{\pi / 2} \int_{0}^{x} e^{-x^{2}} d x
\end{aligned}
$$

All units in the above expressions are Darcy units. 


\section{Calculation of Parameters:}

From match points, khb and $\phi$ chb can be calculated as follows:

$$
\begin{aligned}
& \log \left(p_{D} / x_{D}\right)_{M}=\log (k h b / q \mu x)+\log (\Delta p)_{M} \\
& \text { and } \log \left(t_{D}\right)_{M}=\log \left(k / \phi \mu c_{t} b^{2}\right)+\log t_{M^{\prime}}
\end{aligned}
$$

Where $\left(P_{D} / X_{D}\right)_{M}$ and $\left(t_{D}\right)_{M}$ are the dimensionless variables and the $(\Delta P)_{M}$ and $t_{M}$ are the corresponding real variables for the match point.

The average values of the various parameters were assumed to be the same as shown in Appendix A. Values of $x$ were obtained from figure 1. An approximate value of $10 \times 10^{-6}$ volume/volume/psi was assumed for $c_{t}$ to calculate $\$$ hb. 


\section{APPENDIX C}

TABLES AND FIGURES 
Table 1. Nomenclature of Wells

\begin{tabular}{lll}
$\begin{array}{c}\text { Hell Name } \\
\text { in this Study }\end{array}$ & $\begin{array}{c}\text { Hell Name } \\
\text { in USGS } \\
(1979) \text { Report }\end{array}$ & $\begin{array}{c}\text { Well Name } \\
\text { in Rudisill } \\
(1977) \text { Report }\end{array}$ \\
\hline EE-1 (Earth Energy 1) & Same & same \\
A & Brady-1 & Brady-1 \\
B & Brady-3 & Brady-3 \\
C & Brady-4 & Brady-5 \\
SP-1 & same & Same \\
B-8 (Brady 8) & same & Same \\
G-1 (Grace-1) & --- & - \\
B-5 & Brady-5 & Brady-4
\end{tabular}

Table 2. Results of Analysis Using Theis Curve

Well

kh (md. ft)

Qch (ft/psi)

EE-1

253,100

0.102

A

268,900

0.045

B (Extrapolation I)

266,700

1.31

B (Extrapolation II) 311,100

1.08

C (Extrapolation I) $\quad 268,900$

10.7

C (Extrapolation II)

Theis curve match not possible

$S P-1$

626,633

0.052 
Table 3. Analysis Results Using Linear Flow Solution.

\begin{tabular}{lcc} 
Well & khb $\left(\mathrm{md} . \mathrm{ft}^{2}\right)^{*}$ & $\phi h b\left(\mathrm{ft}^{2}\right)^{*}$ \\
\hline EE-1 & $4.2 \times 10^{9}$ & $2.5 \times 10^{7}$ \\
A & $49 \times 10^{9}$ & $3.0 \times 10^{5}$ \\
B (Extrapolation I) & $1 \times 10^{9}$ & $1.58 \times 10^{8}$ \\
B (Extrapolation II) & Linear Flow Match Poor \\
C (Extrapolation I) & $0.39 \times 10^{9}$ & $2.8 \times 10^{8}$ \\
C (Extrapolation II) & $0.56 \times 10^{9}$ & $\cdots$ \\
SP-1 & Linear Flow Match Not Possible
\end{tabular}

* "b" is the width of the fracture. 
Table 4. Baseline and Drawdown Records for Nells at Brady's Hot Springs Thermal Area, 1977-1980

\begin{tabular}{|c|c|c|c|c|c|c|c|}
\hline & & & .5 & & & & \\
\hline$(B-1)$ & $(B-3)$ & $(B-4)$ & EE-1 & $5 P-1$ & $B-8$ & Notes & Reference \\
\hline
\end{tabular}

1. Pre-test baseline level, Nov. 1977 pump test

2. Level after 22-day pump test of B-B (Nov. 1977)

3. Pre-test baseline level. Feb. 1978 injection test

\begin{tabular}{|c|c|c|c|c|c|c|c|}
\hline 25.5 & 27.4 & - & 9.7 & - & - & 1 & A \\
\hline 30.0 & 20.5 & - & - & - & - & - & $A$ \\
\hline 24.7 & 17.4 & - & $\begin{array}{l}\text { see } \\
\text { note }\end{array}$ & - & - & 2,3 & B \\
\hline 72.5 & 59.0 & - & 47.5 & - & - & 4 & C. D \\
\hline 45.0 & 32.5 & 24.5 & 19.5 & 43.5 & - & 5 & $E$ \\
\hline 60.6 & 44.0 & 45.5 & 33.6 & 46.3 & - & & \\
\hline 42.4 & 31.9 & 21.6 & 15.9 & 44.8 & - & 6 & \\
\hline
\end{tabular}

7. Nater level, Mar. 17, 1981

- Lowest level reached during blow out of B-S June-Det. 1979

5. Pre-tes: baseline level, Nov. 22-DeC. 1, 1980

6. Lowest level reached during drawdown test, Dec. 1980-Jan. 1981

\section{References}

A. Rudise11, 1977

B. Rudisell and Dykstro, 1978

C. U. S. Geological Survey, 1979

D. Geothermal Food Products plant file data. Brady's

E. This : study

\section{Notes}

1. Reference points not specified. Baselines for $A$ and $B$ are averages of measurements made over several-days perlod. Range for $A$ was 25.0 to $26.6 \mathrm{ft}$, B was steady at $17.5 \mathrm{ft}$. Baseline for EE-1 estimated from post-test recovery level.

2. Reference points not speciffed. Baselines for $A$ and $B$ are averages of measurements made over several-days period. Range for $A$ was 24.5-25.2 ft, for B was 17.2-17.8 ft. EE-1 was flowing on 2/7/78 prior to test; killed with 1,000 gal cold water $2 / 7 / 78$; stood at $4.5 \mathrm{ft}$ "from valve top" on $2 / 8 / 7 B$; injection test into $E E-1$ was $2 / 9$; on $2 / 12$ level stood at $5.1 \mathrm{ft}$ "from top of $B P$ valve 2 ft below top of pipe."

3. Probable water levels before GFP plant started.

4. Reference points not spectfied.

5. Averages of numerous measurements during pertod, rounded to nearest $.5 \mathrm{ft}$.

6. Field recording ceased after March 17, 1981. 


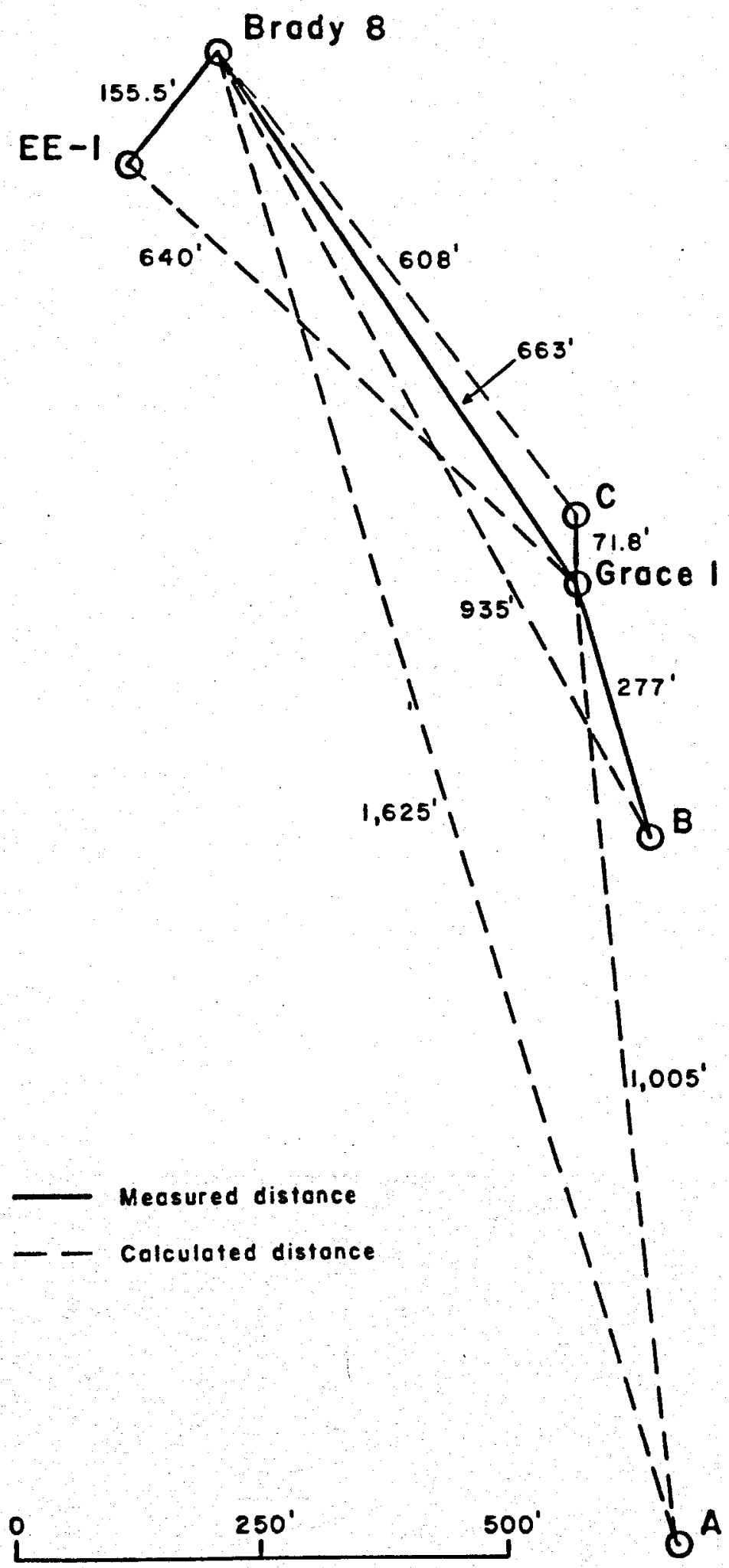




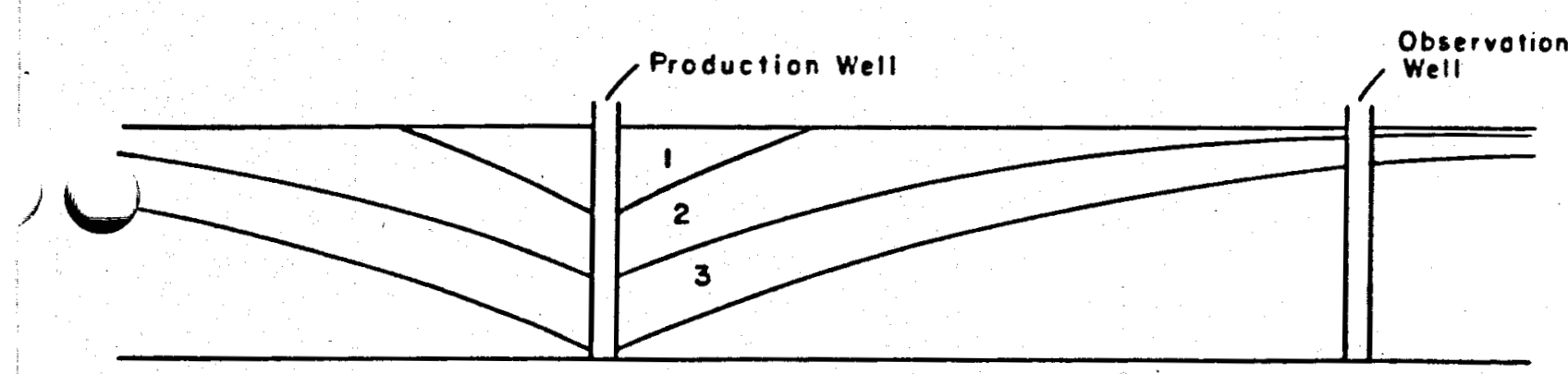

INFINITE SYSTEM

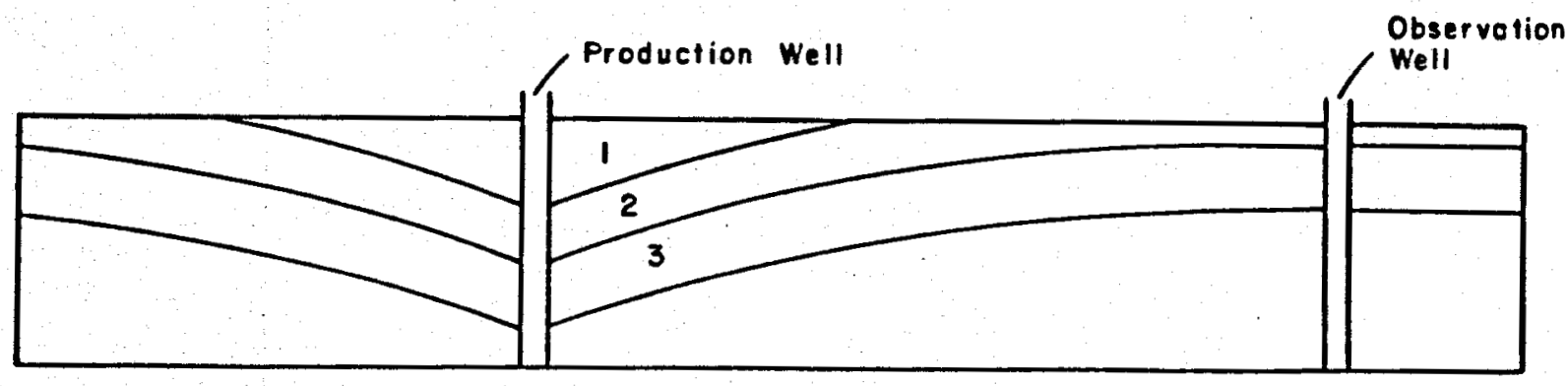

BOUNDED SYSTEM

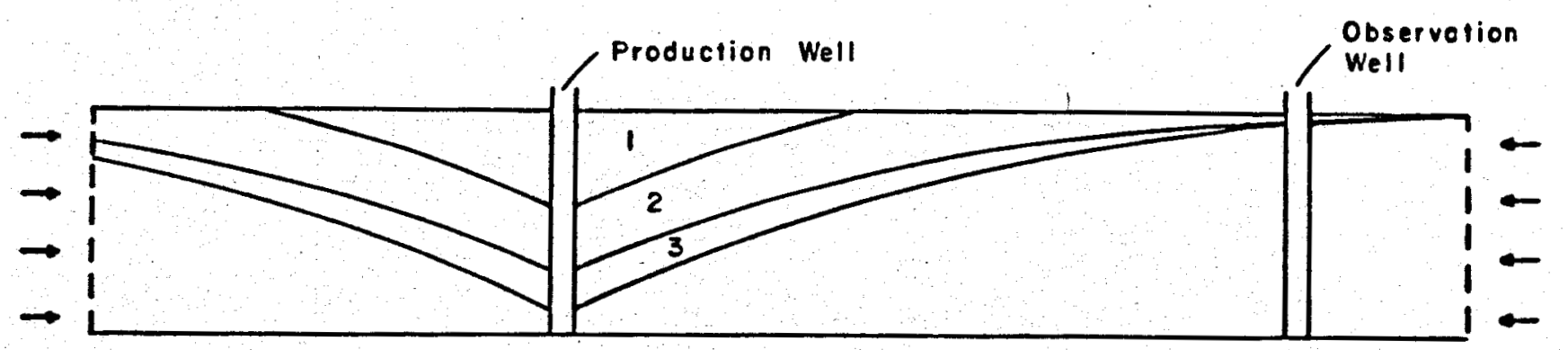

RECHARGED SYSTEM

FIGURE 2. Schematic of reservoir outer boundary conditions. 


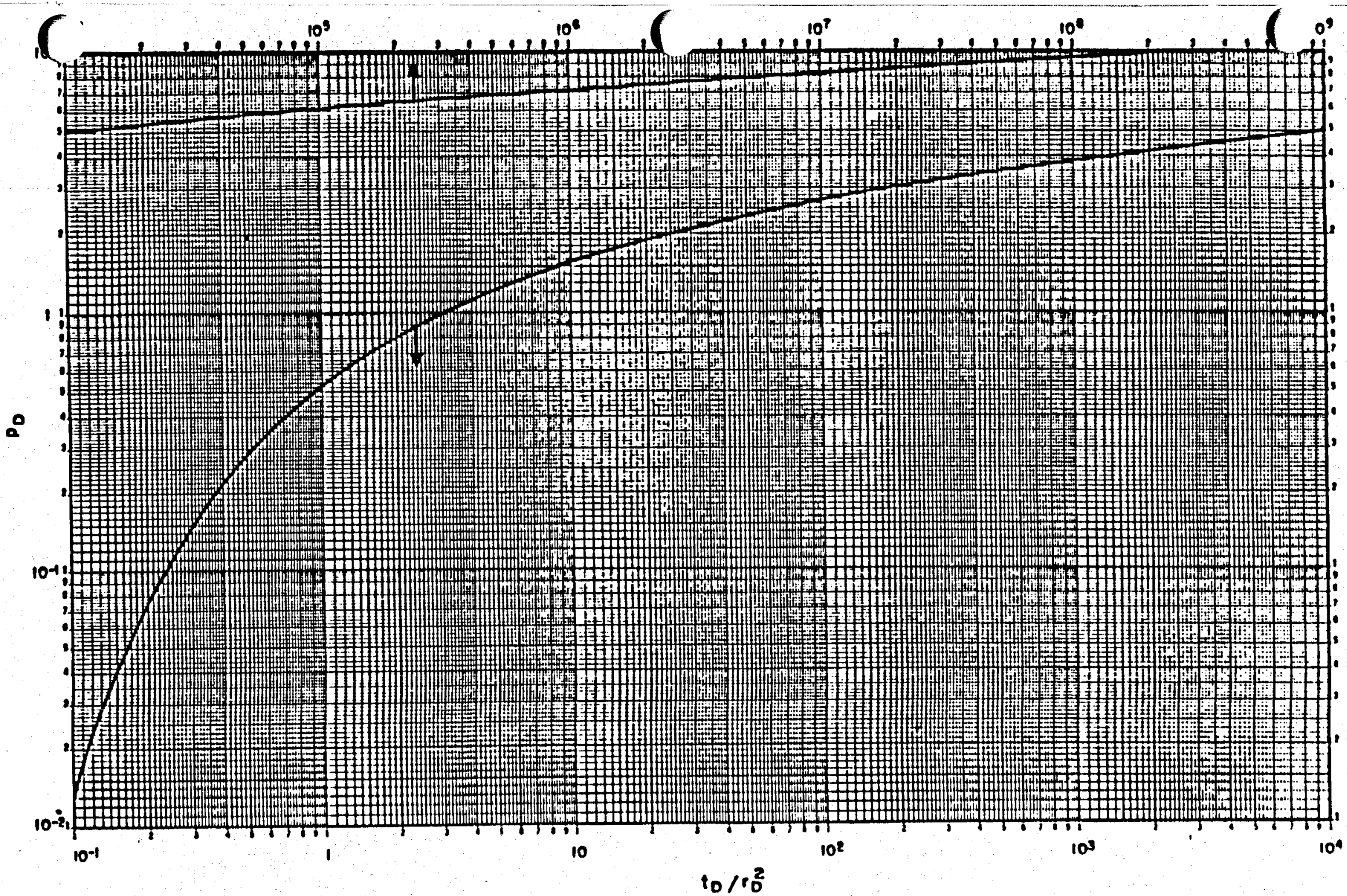

FIGURE 3. Dimensionless pressure for a single well in an infinite system, no wellbore storage, no skin. Exponential-integral solution. (From Soc. Pet. Eng., Monograph Volume 5, 1977.) 


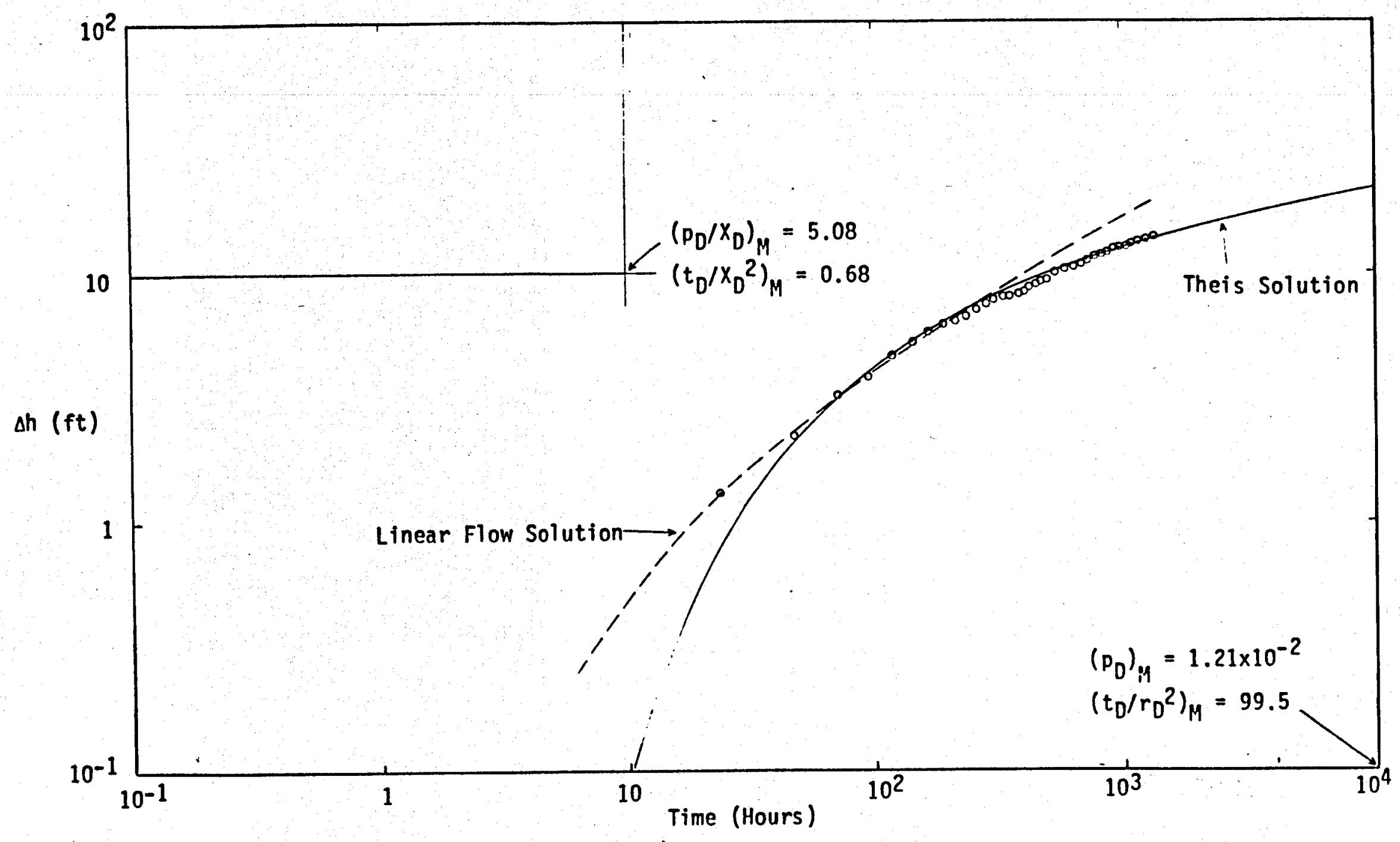

FIGURE 4. Log-Log Plot of Interference Data--Well EE-1. 


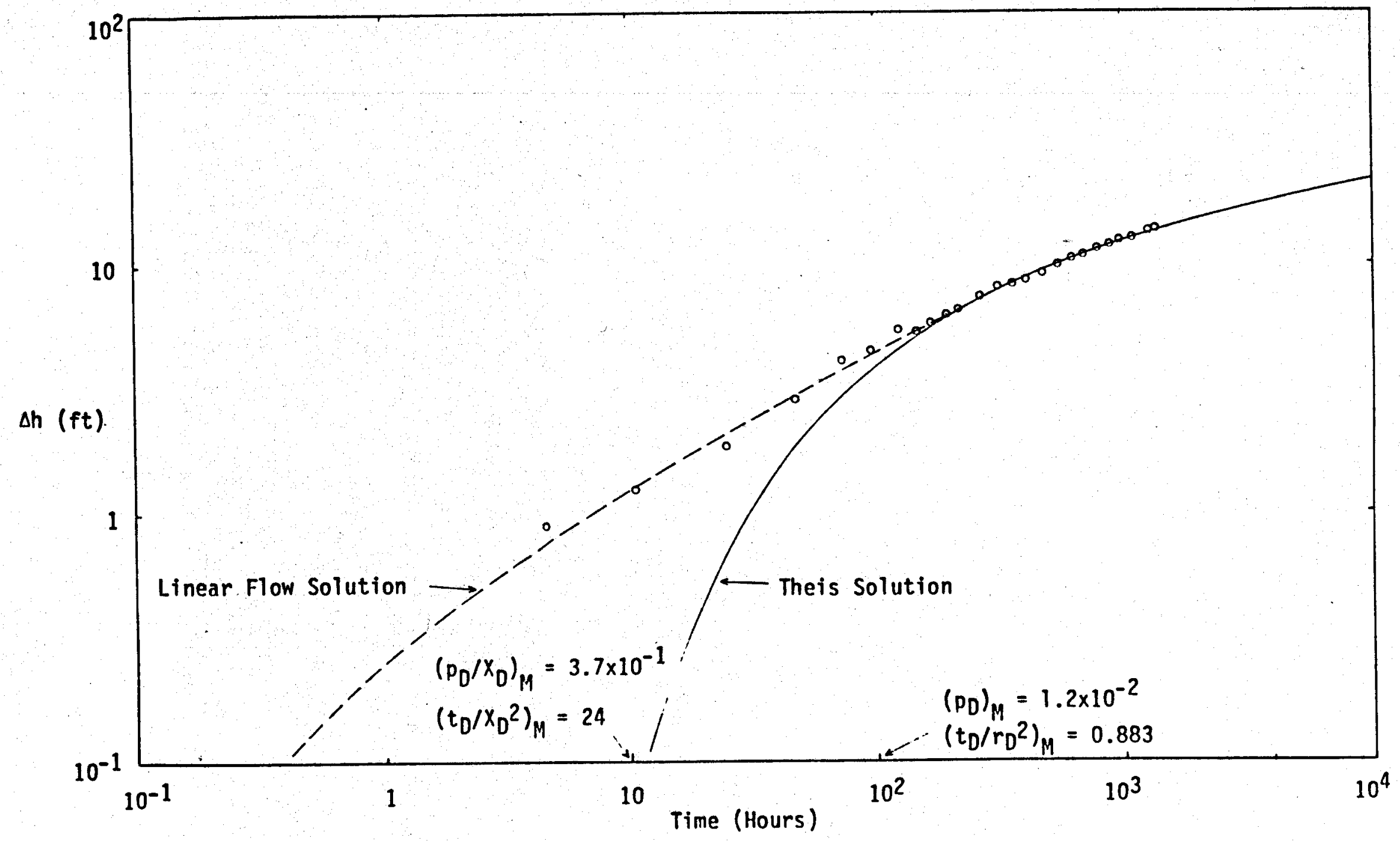

FIGURE 5. Log-Log Plot of Interference Data--Well A. 


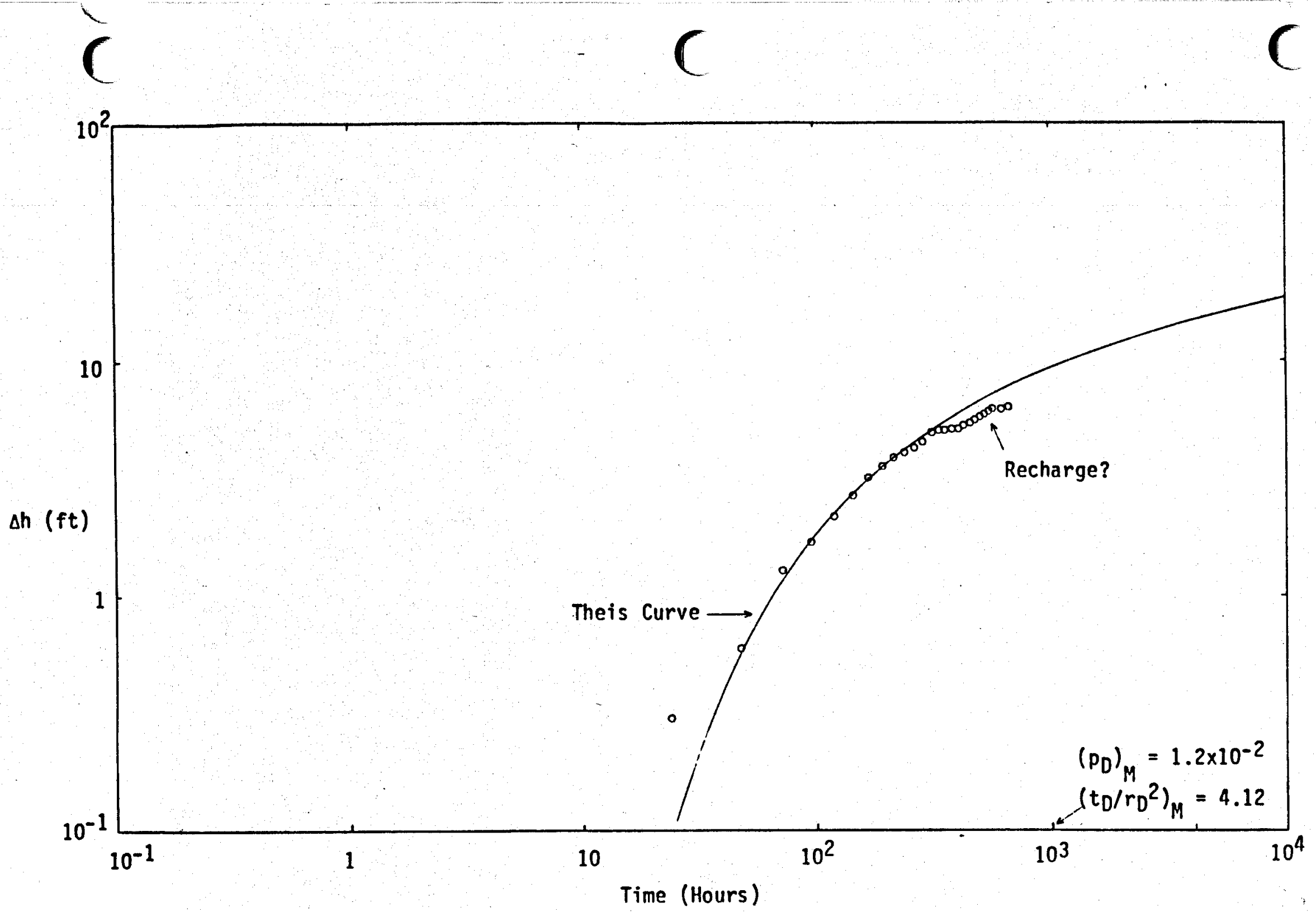

Figure 6. Log-log plot of interference data--Well B (Theis Curve Match, Extrapolation I) 


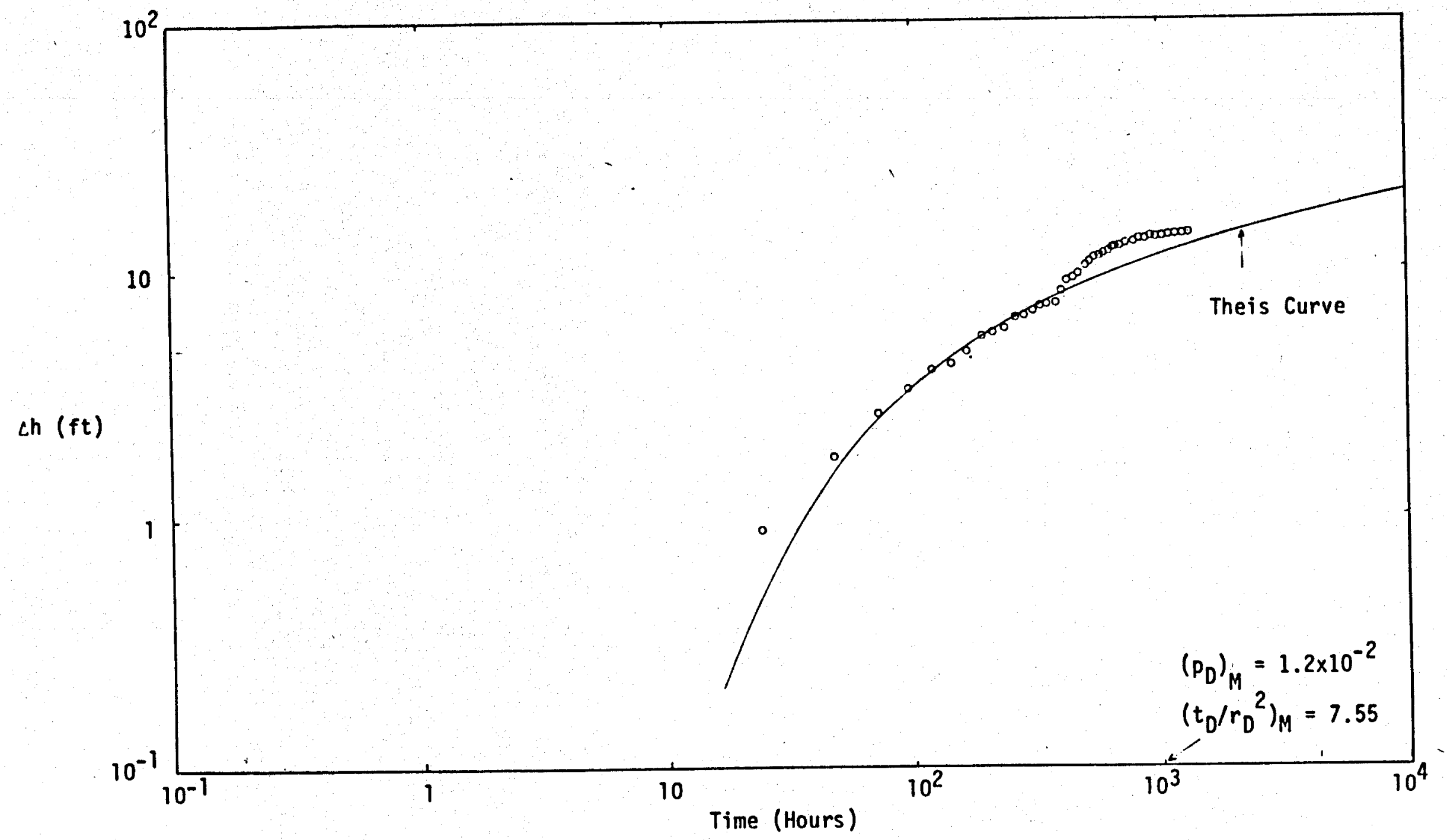

Figure 7. Log-log plot of interference data--Weli C (Theis Curve Match, Extrapolation I) 


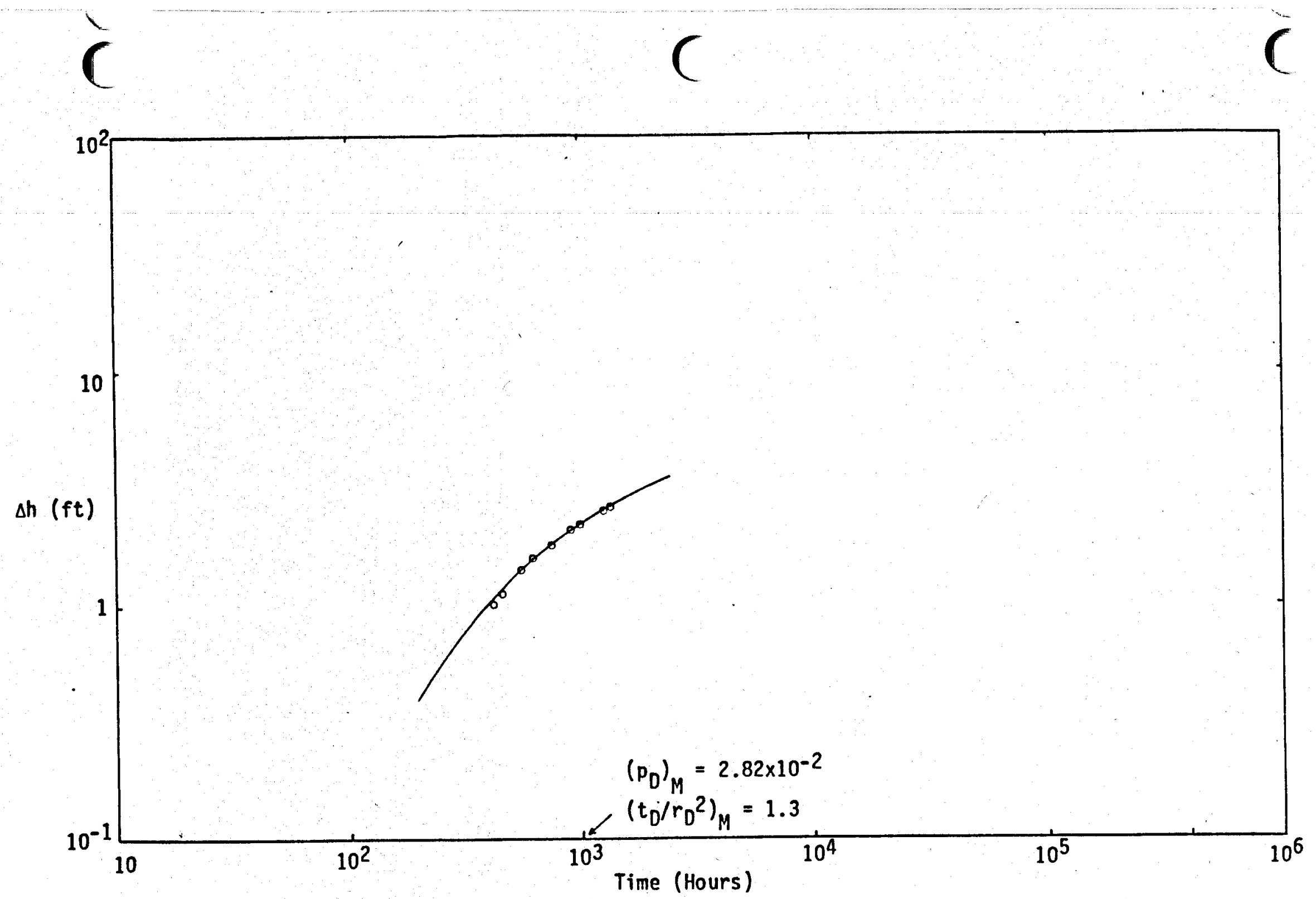

FIGURE 8. Log-log Plot of Interference Data--Well SP-1. 


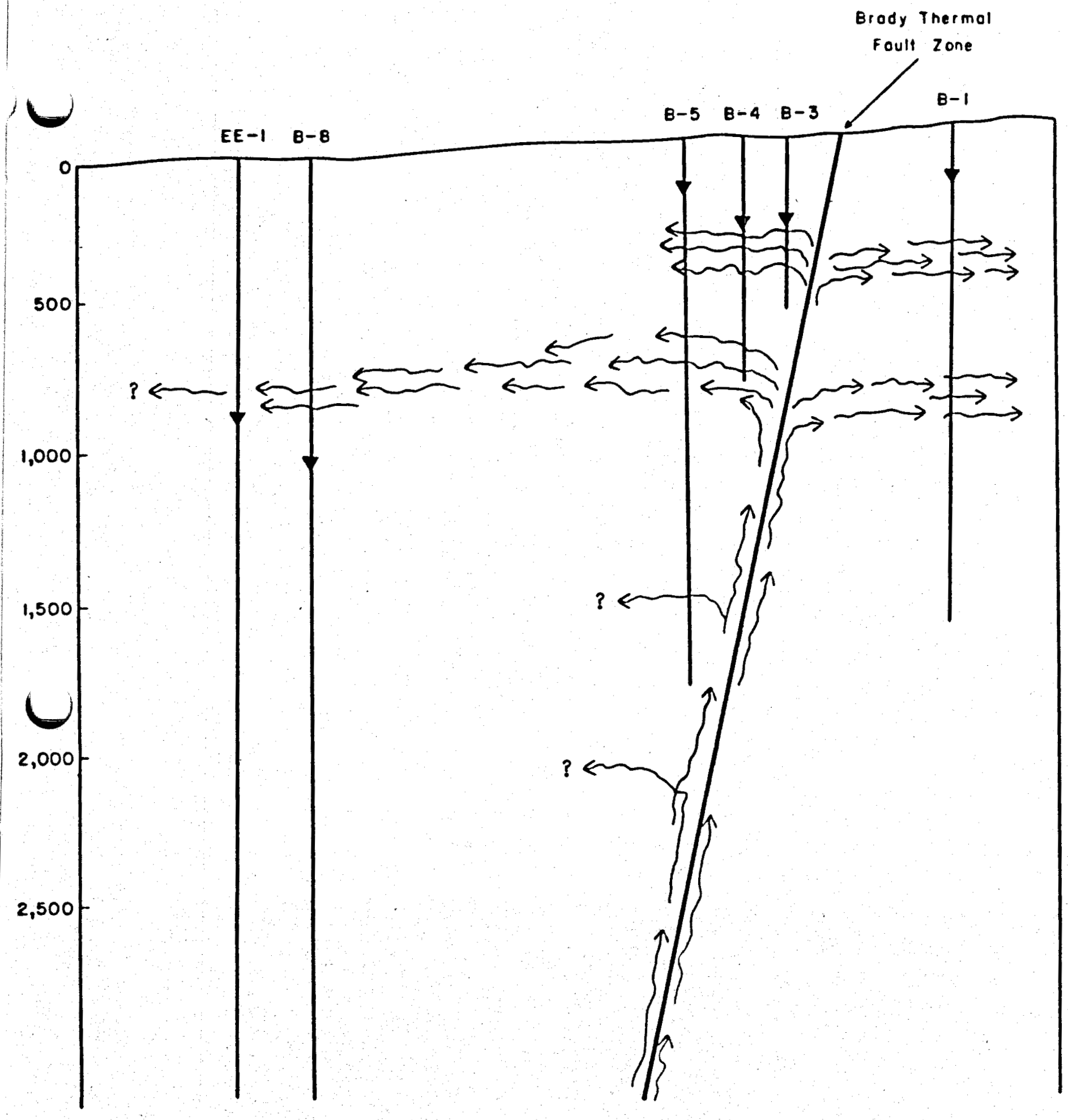

FIGURE 9. A schemotic cross-section of the Brody's Hot Springs areo. 


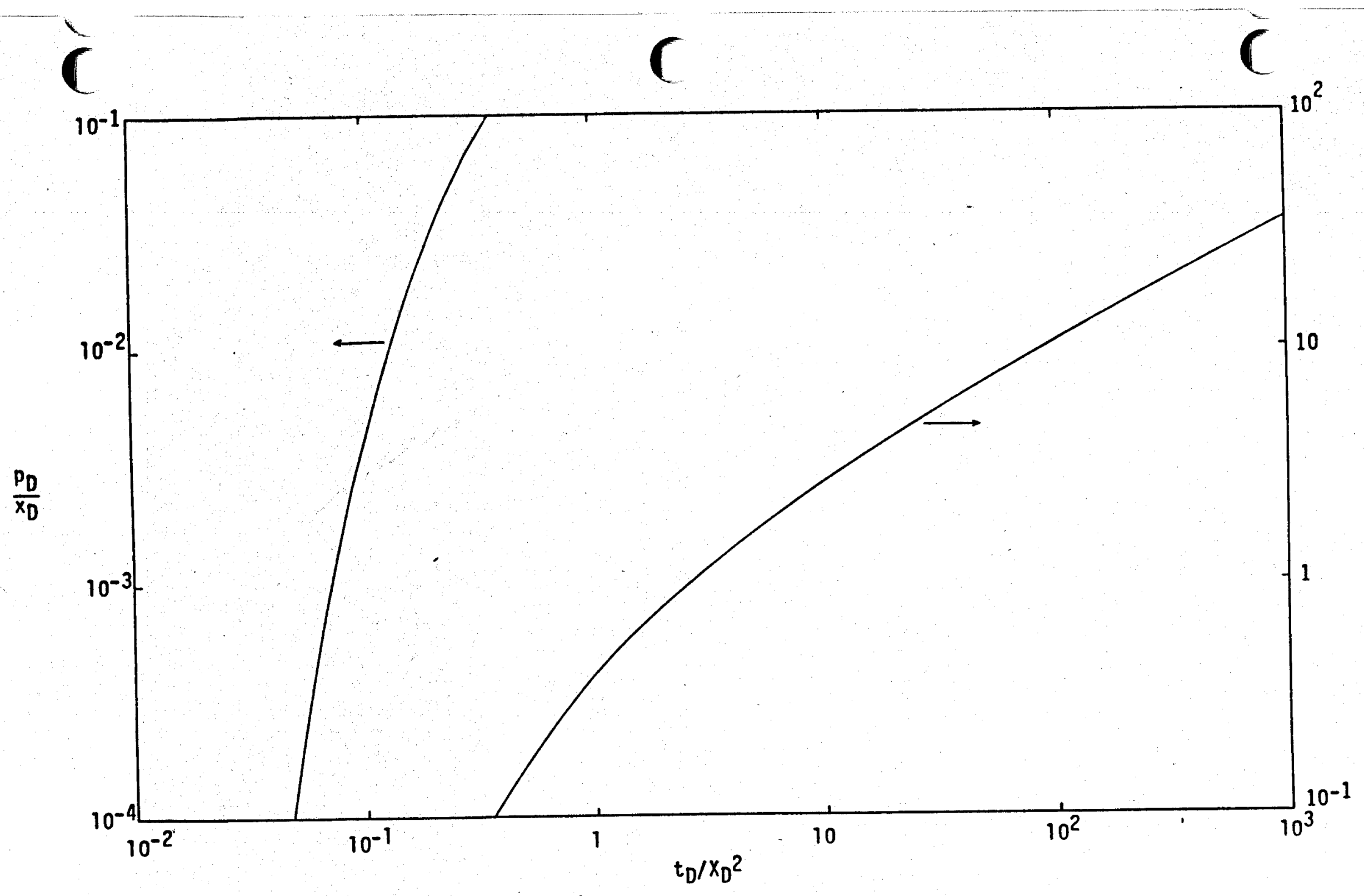

FIGURE 10. Dimensionless Plot of Linear Flow Solution. 


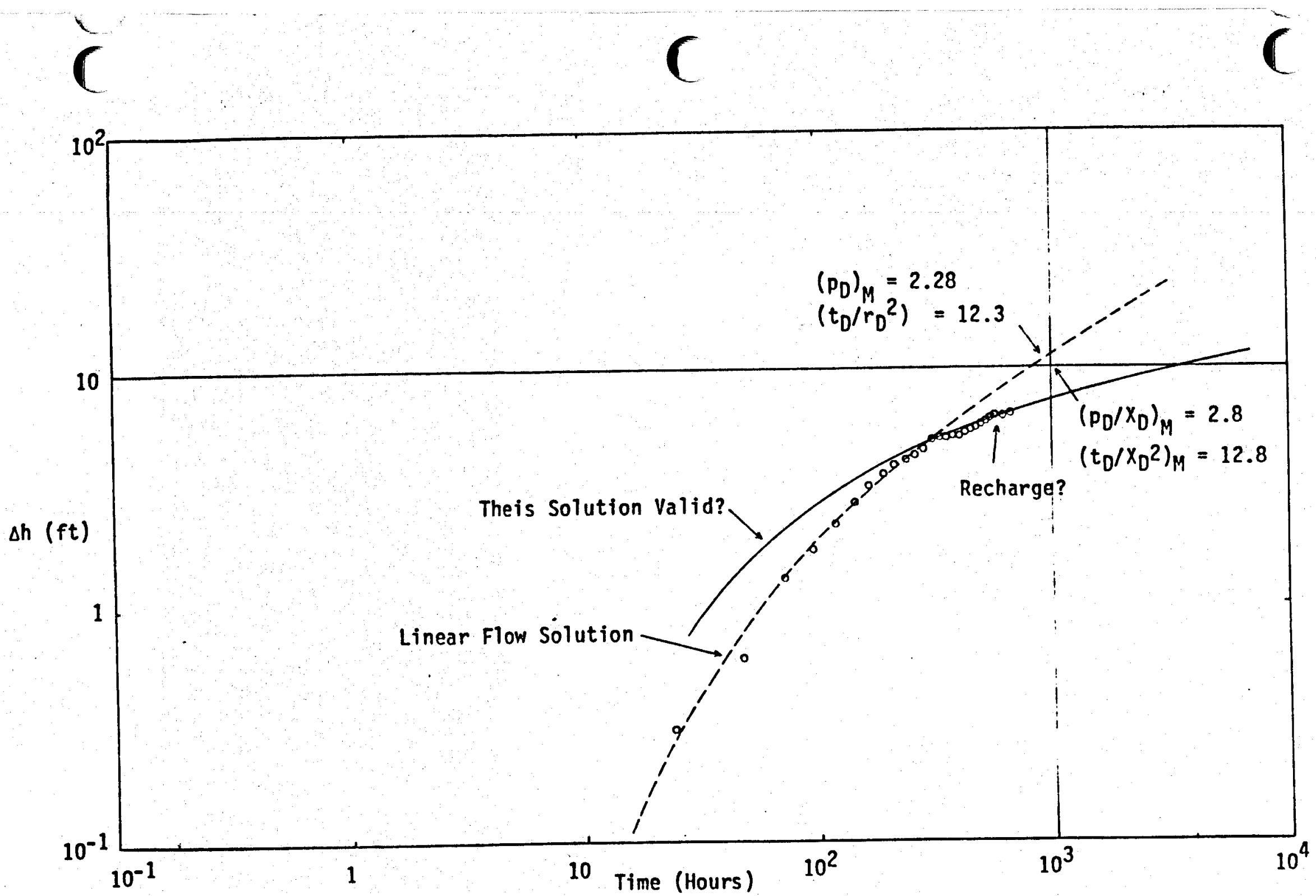

Figure 11. Log-log olot of interference data--Hell B (Linear Flow Solution Match, Extrapolation I ) 


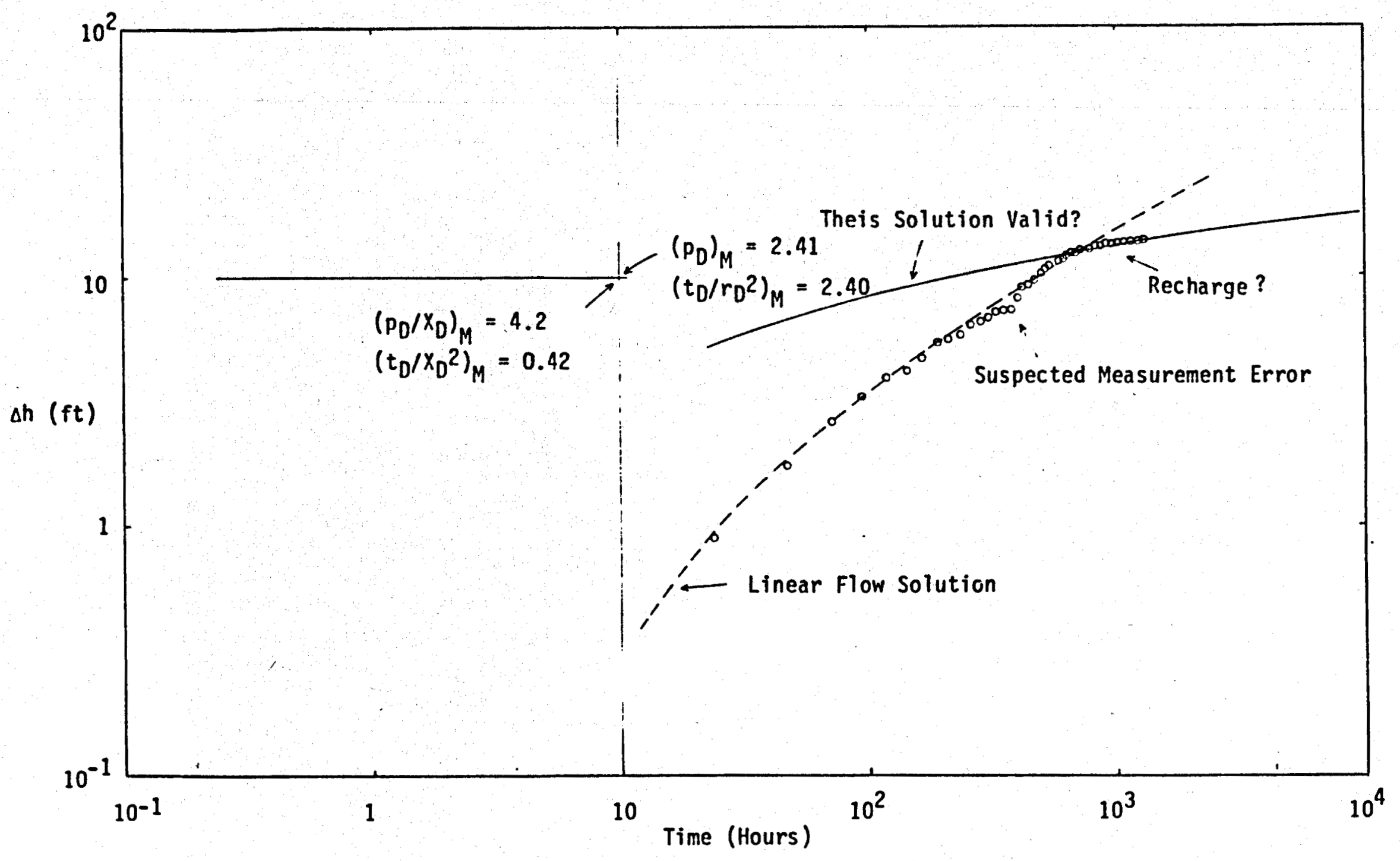

Figure 12. Log-log plot of interference data--Well C (Linear Flow Solution Match, Extrapolation I) 


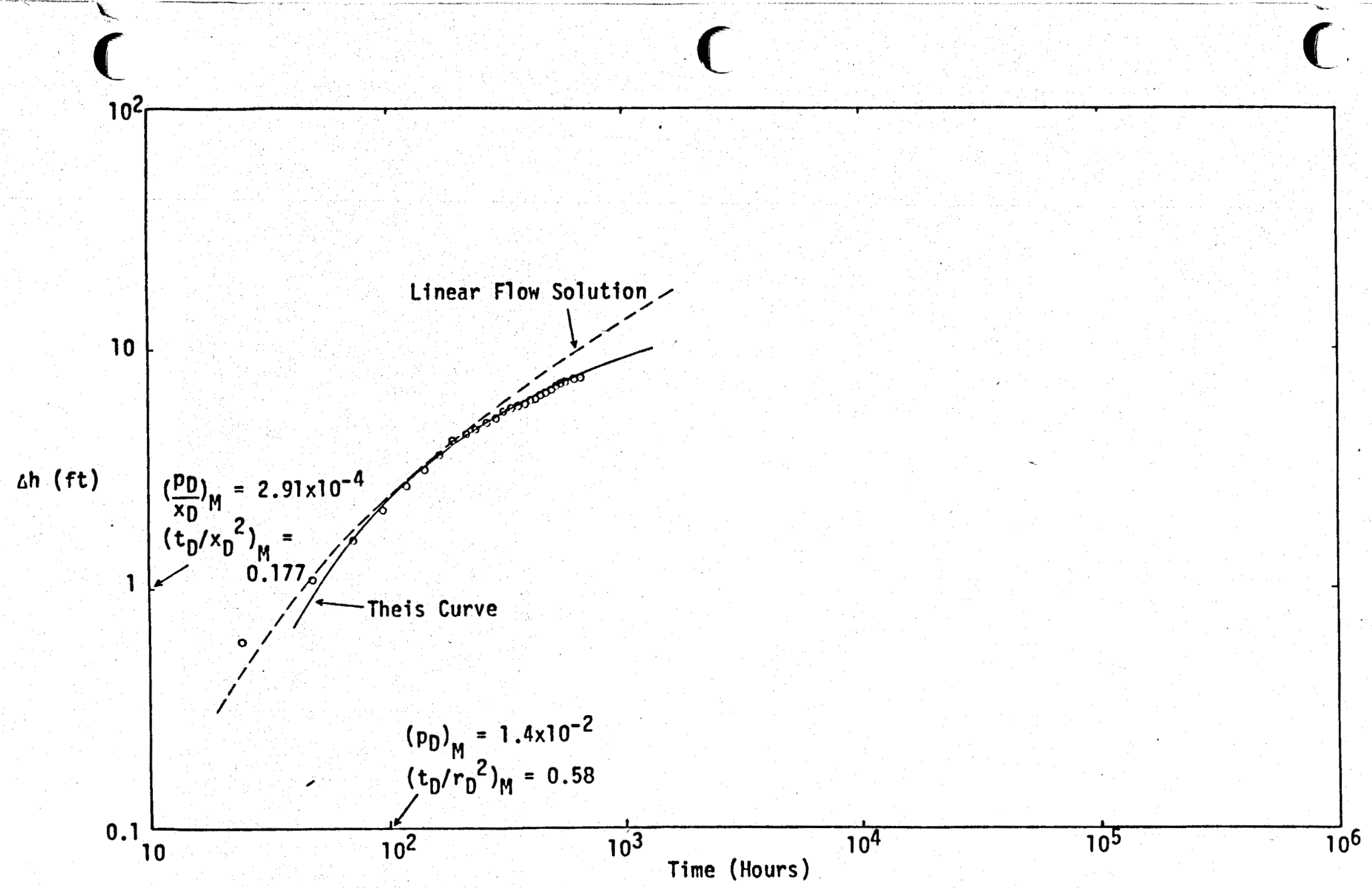

FIGURE 13. Log-Log Plot of Interference Data--Well B (Extrapolation II). 


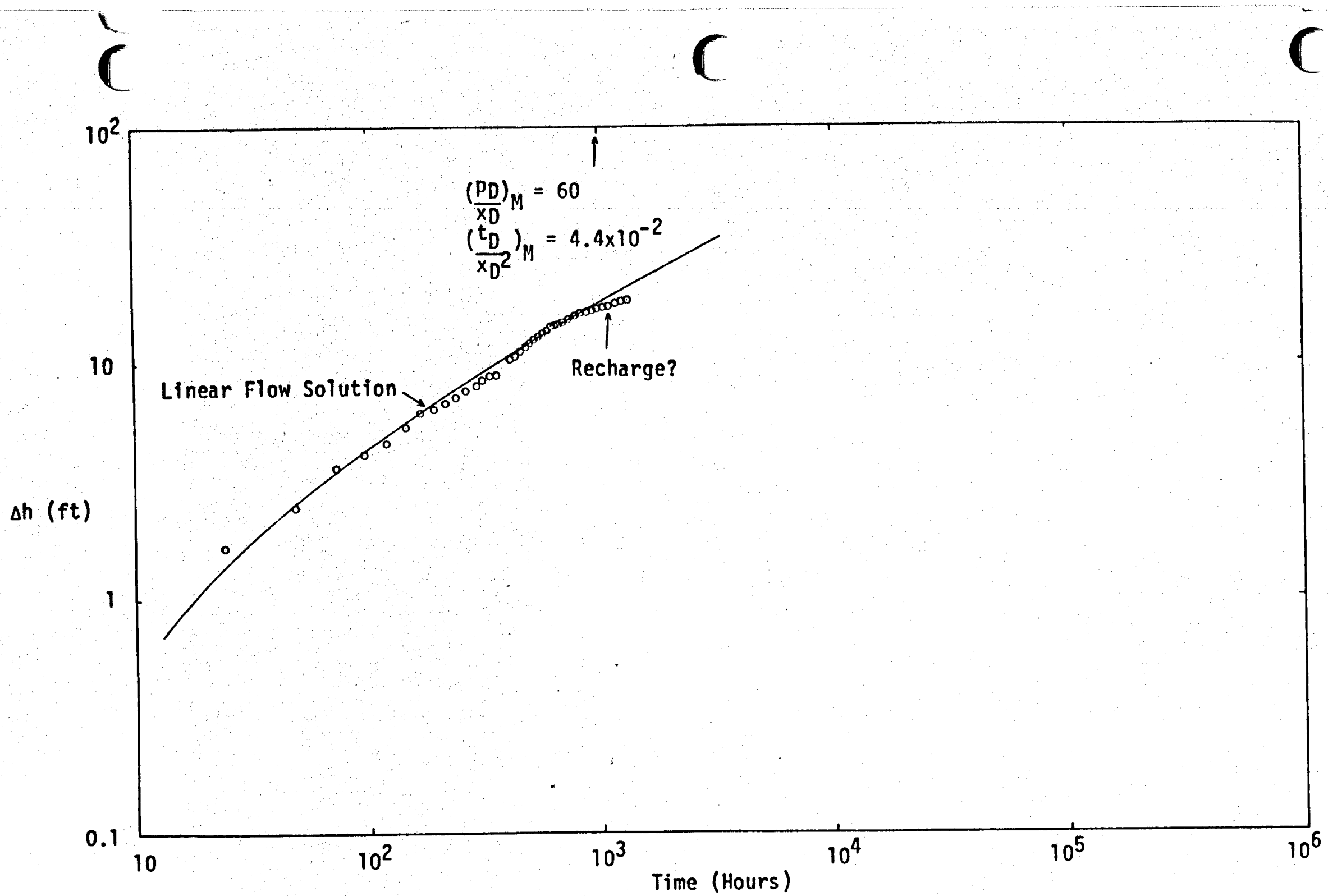

FIGURE 14. Log-Log Plot of Interference Data--Well C (Extrapolation II). 